Bárbara Domingues Bitarello

Seleção natural em genes $H L A$ : uma investigação da localização molecular e temporal dos eventos de seleção

Natural selection on $H L A$ genes: a molecular investigation of the location and timing of selection events

São Paulo 


\title{
Seleção natural em genes $H L A$ : uma investigação da localização molecular e temporal dos eventos de seleção
}

Natural selection on $H L A$ genes: a molecular investigation of the location and timing of selection events

\author{
Dissertação apresentada ao Instituto de \\ Biociências da Universidade de São Paulo, \\ para a obtenção de Título de Mestre em \\ Ciências, na Área de Biologia(Genética) \\ Versão corrigida. A versão original está \\ disponível no Instituto de Biociências da \\ Universidade de São Paulo \\ Orientador: Prof. Dr. Diogo Meyer
} São Paulo 


\section{Ficha Catalográfica:}

Bitarello, Bárbara Domingues

Seleção natural em genes $H L A$ : uma investigação da localização molecular e temporal dos eventos de seleção.

83 páginas + anexos

Dissertação (Mestrado) - Instituto de Biociências da Universidade de São Paulo. Departamento de Genética e Biologia Evolutiva.

1.HLA 2. evolução molecular $3 . d_{N} / d_{S}$ I. Universidade de São Paulo. Instituto de Biociências. Departamento de Genética e Biologia Evolutiva.

Comissão Julgadora:

$\operatorname{Prof}(a) \cdot \operatorname{Dr}(a)$.

Prof(a). Dr(a)

(Orientador)

Prof. Dr. Diogo Meyer 
Aos meus pais, Bia e Flávio, e à minha irmã, Maria. 
"Mas se a literatura não basta para me assegurar de que não estou apenas perseguindo sonhos, então busco na ciência alimento para minhas visões das quais todo pesadume tenha sido excluído..." Italo Calvino, Seis propostas para o próximo milênio 


\section{Agradecimentos}

Agradeço a meus pais, Bia e Flávio, pelo incentivo incondicional, pela paciência e pelo carinho. Aos meus pais "emprestados", Beth e Joe, que são pessoas essenciais em minha vida.

À minha irmã e grande amiga Maria, pelo entusiasmo e feedback positivo, sempre.

À minha avó Tê, por ser uma segunda mãe para mim.

Aos meus amigos: Poliana Cardoso, Denise Nogueira, André Nogueira, Marcela Combat, Luciana Matta, Ramon Vitral, Patrícia Lima, Daniel Marques, Marco Antônio Marinho, Jean Michel Rocha, Mariela Vilas-Boas, Ulisses Belleigolli, Nathalie Giachini, Fabio Nascimento, entre tantos outros.

Aos meus colegas de graduação e do laboratório de Genética Animal (Unicamp), onde aprendi muito.

Aos professores Eduardo Tarazona e Carlos Köehler, por terem me ajudado a encontrar meu caminho para o mestrado.

À família Nogueira ("the Nogueira's"), que me acolheu quando me mudei para São Paulo.

Ao meu orientador e grande incentivador, Diogo Meyer, a quem muito admiro.

Aos meus colegas da USP pelos cafés, pelas discussões, pelas colaborações e pela amizade: Maria Helena Maia, Rodrigo Francisco, Rodrigo Ramalho, Fábio Mendes, Kelly Nunes, Márcia Pincerati e Gustavo França.

Aos professores Tatiana Torres, Paulo Otto e Gabriel Marroig, pela participação em minha banca de qualificação e, portanto, pela colaboração indireta para o aprimoramento desta dissertação.

À Fundação de Amparo à Pesquisa do Estado de São Paulo (FAPESP), pelo auxílio financeiro.

À Alessandra, que me apoiou do início ao fim desta empreitada.

Aos que deixaram saudades.

A todos que não foram mencionados, mas que, indiretamente, participaram comigo. 


\section{Sumário}

I Introdução 1

1 A Razão $d_{N} / d_{S}$ como uma assinatura de seleção natural 1

1.1 A importância do modelo neutro na detecção de evolução adaptativa . . . . . . . . . 1

1.2 Assinaturas de seleção e escalas de tempo . . . . . . . . . . . . . . . . . . . . 3

1.3 Mutações sinônimas e não-sinônimas . . . . . . . . . . . . . . . . . . . . . 9

1.4 Vantagens da estimativa $\omega$ como assinatura de seleção natural . . . . . . . . . . . . . 11

1.5 Escalas de tempo: uma possível limitação da ferramenta $d_{N} / d_{S}$ ? . . . . . . . . . . . 11

2 Seleção sobre genes $H L A \quad 15$

2.1 Estrutura e função do $\mathrm{MHC} \ldots \ldots \ldots \ldots$. . . . . . . . . . . . . . . . . . 15

2.2 Seleção balanceadora em $H L A$. . . . . . . . . . . . . . . . . . . . . . . . . . . . . 17

2.3 Linhagens alélicas em $H L A \quad \ldots \ldots \ldots \ldots \ldots$. . . . . . . . . . . . . . . . . . 22

3 Objetivos $2 \mathbf{2 6}$

$\begin{array}{ll}\text { II Dados e Métodos } & 27\end{array}$

4 Abordagem par-a-par $\quad 27$

4.1 Obtenção de sequências . . . . . . . . . . . . . . . . . . . 27

4.2 Definição de códons ARS, estimativas de divergência e determinação de linhagens . . 28

4.3 Estimação de $d_{N}, d_{S}$ e $d_{N} / d_{S} \ldots \ldots \ldots \ldots \ldots$. . . . . . . . . . . . . 29

4.4 Teste de razão da verossimilhança . . . . . . . . . . . . . . . . . . . . . 31

4.5 Análises estatísticas . . . . . . . . . . . . . . . . . . . . . 32

4.6 Simulação . . . . . . . . . . . . . . . . . . . . . . . . . 34

5 Abordagem filogenética $\quad 35$

5.1 Obtenção de sequências . . . . . . . . . . . . . . . . . . 36

5.2 Detecção e remoção de sequências recombinantes . . . . . . . . . . . . . . . . 36

5.3 Determinação de sítios sob seleção positiva . . . . . . . . . . . . . . . . . . 37

5.4 Análises filogenéticas de modelos de seleção sobre linhagens específicas . . . . . . . . 39

III Resultados e Discussão $\quad 41$ 
6 Análises par-a-par $\quad 41$

7 Análises filogenéticas $\quad 50$

7.1 Determinação de sítios sob seleção positiva . . . . . . . . . . . . . . . . . 50

7.2 Comparação entre classificações de códons baseadas em estrutura molecular e evidências de seleção . . . . . . . . . . . . . . . . . . . . . . . . 59

7.3 Alvos de seleção em $H L A$ : alelos individuais ou linhagens alélicas? . . . . . . . . . . 64

7.4 Escala temporal dos eventos de seleção em HLA: seleção em ramos internos e terminais 67

8 Discussão e Conclusão $r$

$\begin{array}{lr}\text { Referências } & 74\end{array}$

$\begin{array}{llr}\text { IV Anexos } & 84\end{array}$ 


\section{Lista de Tabelas}

1 Dados de sequência para as análises par-a-par . . . . . . . . . . . . . . . . . . 28

2 Efeito da remoção de pares com $\omega$ alto . . . . . . . . . . . . . . . . . . . 33

3 Dados de sequência para as análises de seleção sobre códons . . . . . . . . . . . . 38

4 Dados de sequência para as análises de seleção sobre linhagens . . . . . . . . . . . . 39

5 Substituições sinônimas e não-sinônimas em locs de $H L A$ classe I . . . . . . . . . . . 41

$6 \quad$ Estimativas de parâmetros das análises par-a-par . . . . . . . . . . . . . . . . 43

7 Teste de Mantel entre $\omega_{A R S}$ e $d_{S(n \tilde{a} o-A R S)} \ldots \ldots \ldots \ldots$. . . . . . . . . . 47

8 Valores de $\omega_{A R S}$ para pares "I" e "E" . . . . . . . . . . . . . . . . . . . . . 47

$9 \quad$ LRT entre os modelos de seleção sobre códons $(\mathrm{CR}) \quad \ldots \ldots$. . . . . . . . . . . . . 51

10 LRT entre os modelos de seleção sobre códons $(\mathrm{SR}) \quad \ldots \ldots$. . . . . . . . . . . . . . 52

11 Estimativas de parâmetros sob modelos de seleção sobre códons para $H L A$ - $A(\mathrm{CR})$. 53

12 Estimativas de parâmetros sob modelos de seleção sobre códons para $H L A-B(\mathrm{CR})$. 54

13 Estimativas de parâmetros sob modelos de seleção sobre códons para $H L A-C$ (CR) . 55

14 Estimativas de parâmetros sob modelos de seleção sobre códons para $H L A$ - $A$ (SR) . 56

15 Estimativas de parâmetros sob modelos de seleção sobre códons para $H L A-B$ (SR) . 57

16 Estimativas de parâmetros sob modelos de seleção sobre códons para $H L A-C$ (SR) . 58

17 Tabela de contingência entre códons BIT e códons CHEV . . . . . . . . . . . . . . 62

18 Tabela de contingência entre códons BIT e códons $\mathrm{CHEV} \pm 1$. . . . . . . . . . . . . 64

19 Estimativas filogenéticas de $\omega_{A R S}(\mathrm{E} \times \mathrm{I})(\mathrm{CR}, \mathrm{CHEV}) \ldots \ldots . \ldots$

20 Estimativas filogenéticas de $\omega_{A R S}(\mathrm{E} \times \mathrm{I})(\mathrm{SR}, \mathrm{CHEV}) \ldots \ldots \ldots$

21 Estimativas de parâmetros para ramos E e I $(\mathrm{CR}, \mathrm{CHEV}) \ldots \ldots$. . . . . . . . . 66

22 Estimativas de parâmetros para ramos E e I (SR, CHEV) . . . . . . . . . . . . 66

23 Estimativas de parâmetros para ramos E e I $(\mathrm{CR}, \mathrm{CHEV}+)$. . . . . . . . . . . 67

24 Estimativas filogenéticas de $\omega_{A R S}(\mathrm{In} \times \mathrm{T})(\mathrm{CR}, \mathrm{CHEV}) \ldots \ldots$. . . . . . . 68

25 Estimativas filogenéticas de $\omega_{A R S}(\operatorname{In} \times \mathrm{T})(\mathrm{SR}, \mathrm{CHEV}) \ldots \ldots \ldots$

26 Estimativas de parâmetros para ramos In e T (CR, CHEV) . . . . . . . . . . . . . 69

27 Estimativas de parâmetros para ramos In e T (SR, CHEV) . . . . . . . . . . . . . 69

28 Estimativas de parâmetros para ramos In e T $(\mathrm{CR}, \mathrm{CHEV}+)$. . . . . . . . . . . . 70 


\section{Lista de Figuras}

1 Algumas assinaturas de seleção positiva . . . . . . . . . . . . . . . . . . . . 4

2 Relação entre $\gamma$ e $d_{N} / d_{S} \ldots \ldots \ldots \ldots \ldots \ldots \ldots \ldots$

3 Mapa genético da região $H L A \ldots \ldots \ldots \ldots$

4 Estrutura molecular e diversidade genética das moléculas MHC. . . . . . . . . . . . 16

5 Polimorfismos trans-específicos f. . . . . . . . . . . . . . . . . 18

6 Efeitos da seleção natural sobre as genealogias gênicas e frequências alélicas . . . . . 19

$7 \quad$ Árvore filogenética parcial de $H L A-B \ldots \ldots \ldots \ldots$. . . . . . . . . . . . 23

$8 \quad H L A-A$ : Comportamento de $\omega_{A R S}$ e $\omega_{(n \tilde{a} o-A R S)}$ em função da divergência . . . . . 42

$9 \quad H L A-B$ : Comportamento de $\omega_{A R S}$ e $\omega_{(n \tilde{a} o-A R S)}$ em função da divergência . . . . . 44

$10 H L A-C$ : Comportamento de $\omega_{A R S}$ e $\omega_{(n \tilde{a} o-A R S)}$ em função da divergência . . . . . 45

$11 H L A$-A: Relação entre $\omega_{A R S}$ e $d_{S(n \tilde{a} o-A R S)} \ldots \ldots \ldots \ldots$

12 LRT para análises par-a-par . . . . . . . . . . . . . . . . . . . . 48

13 Histograma de valores de correlação para bases de dados simuladas de $H L A-A \quad$. . 49

14 Comparação entre duas classificações de códons ARS e dois estudos de seleção sobre códons . . . . . . . . . . . . . . . . . . . . . . . 61

15 Seleção positiva sobre códons vizinhos aos ARS . . . . . . . . . . . . . . . 63

A.1 HLA-B: relação entre $\omega_{A R S}$ e $d_{S(n a \tilde{o}-A R S)} \ldots \ldots \ldots \ldots$. . . . . . . . . 87

A.2 HLA-C: relação entre $\omega_{A R S}$ e $d_{S(n a \tilde{o}-A R S)} \ldots \ldots \ldots \ldots$. . . . . . . . . 87

A.3 HLA - A: Comportamento de $d_{N}$ e $d_{S}$ em função da divergência . . . . . . . . . . 88

A.4 HLA - B: Comportamento de $d_{N}$ e $d_{S}$ em função da divergência . . . . . . . . . . . 89

A.5 HLA - C: Comportamento de $d_{N}$ e $d_{S}$ em função da divergência . . . . . . . . . . . 90

A.6 HLA-A: teste de Mantel entre $\omega_{A R S}$ e $d_{S(n \tilde{a} o-A R S)} \ldots \ldots \ldots$. . . . . . . . . . . . 91 


\section{Lista de Algoritmos}

1 Script em R para construção de uma matriz simétrica . . . . . . . . . . . . . 84

2 Script em R para execução de um teste $t$ com permutação . . . . . . . . . . . 85

$3 \quad$ Script em R para execução de um teste de Mantel . . . . . . . . . . . . . . . . 86 


\section{Resumo}

A comparação de taxas de substituição não-sinônimas $\left(d_{N}\right)$ e sinônimas $\left(d_{S}\right)$ permite inferir quais regimes de seleção operaram sobre regiões codificadoras. Genes com $d_{N} / d_{S}>1$ são candidatos a estarem sob seleção positiva, e scans genômicos em busca dessa assinatura se revelaram uma ferramenta poderosa. Trata-se de um método robusto, uma vez que assume-se que tais sítios estão intercalados nas regiões do genoma sob estudo (e portanto partilham a mesma história demográfica), e que têm como foco a variação em genes específicos, eliminando ambiguidades acerca do alvo da seleção. Por outro lado, o critério de $\omega>1$ para que genes estejam sob seleção positiva é muito conservador. Isso ocorre porque geralmente apenas alguns códons estão sob seleção positiva, enquanto a maior parte das mutações não-sinônimas são deletérias e, portanto, estão sob seleção purificadora. Por isso, convencionou-se analisar subconjuntos de códons em busca de seleção, seja através de uma base de dados mais restrita ou através de modelos que estimam diferentes valores de $\omega$ para subconjuntos de códons, tornando possível inferir quais deles estão sob seleção positiva.

Os genes das moléculas MHC têm vários padrões de variação que indicam que algum tipo de seleção balanceadora atuou sobre eles (alta diversidade, grande diferenciação entre alelos e a existência de polimorfismos trans-específicos). Os genes $H L A$ constituem um subconjunto de genes do MHC humano e estão localizados no braço curto do cromossomo 6. Os genes clássicos de classe I ( $H L A-\mathrm{A}, H L A-B$ e $H L A-C)$ são expressos na maior parte das células somáticas e desempenham papel central no processo de resposta imune adaptativa, capturando e apresentando peptídeos na superfície celular. A região da molécula de MHC à qual antígenos são ligados para serem apresentados a linfócitos $\mathrm{T}$, dessa forma iniciando a resposta imune adaptativa, é conhecida como sítio de reconhecimento do antígeno (ARS). É bem estabelecido que os códons ARS apresentam taxas de substituição não-sinônimas maiores que as taxas sinônimas para esses três locos, consistente com um efeito de seleção balanceadora levando a maior variabilidade funcional na região da molécula que interage com o peptídeo.

Os genes $H L A$ clássicos apresentam centenas de alelos, e esses constituem clados que reúnem alelos filogeneticamente relacionados e com similaridades funcionais. Apesar de não haver controvérsia sobre a existência de seleção sobre genes $H L A$, não existe consenso acerca da importância relativa da seleção sobre linhagens alélicas e sobre alelos individuais na diversificação dos alelos de $H L A$, e essa foi a questão que decidimos investigar. Nossa hipótese nula foi a de que as linhagens foram os alvos da seleção e a hipótese alternativa foi a de que os alelos individuais foram alvos da seleção ao longo da história evolutiva dos genes $H L A$.

Buscamos, primeiramente, fazer uma validação do método de inferência de $d_{N} / d_{S}$ usando como estudo de caso os códons ARS e sua relação com a capacidade de inferência. Constatamos que, dos códons que encontramos sob seleção positiva, todos (exceto um) estão também na 
classificação clássica dos códons ARS ou a \pm 1 códon de distância destes, mostrando que existem evidências de seleção em sítios vizinhos aos ARS. Portanto, uma classificação expandida, que inclua os códons sob seleção que não estão nas classificações ARS comumente utilizadas, deveria aumentar o poder estatístico de testes de modelos de seleção nos genes $H L A$.

Ao comparar os resultados obtidos em análises filogenéticas com bases de dados com e sem recombinantes, verificamos que a remoção de alelos recombinantes altera as estimativas de parâmetros, a identificação de códons com evidência de seleção e a significância dos testes de comparação de modelos.

Nossas análises mostraram que $\omega$ é significativamente maior para pares de alelos de linhagens diferentes do que para pares de alelos de uma mesma linhagem e que existe uma correlação positiva significativa entre o tempo de divergência dos alelos e as estimativas de $\omega$. Verificamos, ainda, que é possível rejeitar um modelo nulo de uma razão $\omega$ estimada para todos os ramos da árvore filogenética e favorecer um modelo em que $\omega$ é estimado separadamente para ramos entre e intra-linhagens em $H L A$-C. Em $H L A$ - $A$ e $H L A-C$, $\omega$ é significativamente $>1$ entre linhagens. Mostramos também, para os mesmos locos, $\omega$ é significativamente $>1$ nos ramos internos. Em $H L A-C$, o modelo que estima $\omega$ separadamente para ramos internos e terminais foi favorecido.

Nossos resultados mostram que a intensidade de seleção atuando entre linhagens é maior do que aquela dentro de linhagens. Entretanto, mesmo dentro de linhagens, há fortes evidências de desvios de neutralidade, sugerindo a ação da seleção natural. 


\begin{abstract}
The comparison of non-synonymous $\left(d_{N}\right)$ and synonymous $\left(d_{S}\right)$ substitution rates allows us to infer selection schemes which operated in coding regions. Genes with $d_{N} / d_{S}>1$ are candidates to be under positive selection, and genome scans in search for this signature have proved to be a powerful tool. It is a robust method, since it is assumed that such sites are interspersed in regions of the genome under study (and therefore share the same demographic history), and which focuses on the variation in specific genes, eliminating ambiguities about the target of selection. On the other hand, the criterion of $\omega>1$ for genes to be considered under positive selection is very conservative. This is because usually only a few codons are under positive selection, while most non-synonymous mutations are deleterious and are thus under purifying selection. Therefore, it has been conventioned to analyze subsets of codons in search of selection, either through a narrower data set or through models that calculate different $\omega$ values for subsets of codons, making it possible to infer which of them are under positive selection.

The MHC molecules' genes have different variation patterns that indicate some sort of balancing selection acted upon them (high diversity, large differentiation between alleles and the existence of trans-specific polymorphisms). HLA genes are a subset of human MHC genes and are located on the short arm of chromosome 6. The classical class I genes ( $H L A-A, H L A-B$ and $H L A-C)$ are expressed in most somatic cells and play a central role in the process of adaptive immune response, capturing and presenting peptides on the cell surface. The region of the MHC molecule to which antigens are bound to be presented to $\mathrm{T}$ lymphocytes, thereby initiating the adaptive immune response, is known as the antigen recognition site (ARS). It is well established that ARS codons have higher non-synonymous than synonymous substitution rates on these three loci, consistent with an effect of balancing selection leading to greater variability in the functional region of the molecule that interacts with the peptide.
\end{abstract}

The classical HLA genes have hundreds of alleles, and these constitute clades which group phylogenetically related and functionally similar alleles. Although there is no controversy about the existence of selection acting on $H L A$ genes, there is no consensus on the relative importance of selection on allelic lineages and on individual alleles on the diversification of $H L A$ alleles, and that was the question we decided to investigate. Our null hypothesis was that lineages were targets of selection and the alternative hypothesis was that the individual alleles were targets of selection during the evolutionary history of $H L A$ genes.

We sought, first, to make a validation of the method of inference $d_{N} / d_{S}$ using as a case study the ARS codons and their relation to the ability of inference. Of all the codons under selection we found, all (except one) are also in the classification of classical ARS codons or \pm 1 codon away from these, showing that there is evidence of selection at nearby sites to the ARS. Therefore, an expanded classification, which includes the codons under selection that are not commonly used in the ARS classifications, should increase the statistical power of selecion model tests on the $H L A$ genes.

By comparing the results obtained in phylogenetic analysis using data sets with or without recombinants, we found that the removal of recombinant alleles alters the parameter estimates, the identification of codons xiii 
with evidence of selection and the significance of model comparison tests.

Our analysis showed that $\omega$ is significantly higher for pairs of alleles from different lineages than for pairs of alleles from the same lineage and that there is a significant positive correlation between time of divergence of alleles and estimates of $\omega$. We also verified that it is possible to reject a null model of one $\omega$ estimated for all branches of the phylogenetic tree and favor a model where $\omega$ is estimated separately for branches within and between lineages of $H L A-C$. In $H L A-A$ and $H L A-C, \omega$ is significantly $>1$ between lineages. We also show that, for these same loci, $\omega$ fis significantly greater than one or internal branches. In $H L A-C$, the model that estimates $\omega$ separately for terminal and internal branches was favored.

Our results show that the intensity of selection between lineages is greater then within them. However, even within lineages, there is a strong evidence of deviation from neutrality, suggesting the action of natural selection. 


\section{Parte I}

\section{Introdução}

\section{A Razão $d_{N} / d_{S}$ como uma assinatura de seleção natural}

\subsection{A importância do modelo neutro na detecção de evolução adaptativa}

Há décadas os geneticistas de população se preocupam em quantificar a contribuição da seleção natural como força moldadora da variabilidade observada na natureza. Uma escola de pensamento sustenta que a maior parte da variabilidade observada entre e dentro de espécies afeta a aptidão dos organismos e, portanto, está sujeita à seleção natural (Gillespie, 1991; revisado em Nielsen, 2005). Conforme inicialmente proposto por Darwin em 1859, a seleção natural - o princípio de que características hereditárias que aumentam a aptidão do indivíduo tendem a se tornar mais frequentes nas populações ao longo do tempo e características que diminuem a aptidão tendem a ser eliminadas - seria, de acordo com esta escola de pensamento, a principal força moldadora da evolução (Fisher, 1930).

O conceito original de seleção natural pode ser desmembrado em três categorias: a seleção direcional (positiva ou negativa) e a seleção balanceadora. A seleção positiva atua sobre uma mutação adaptativa aumentando-a de frequência na população. A seleção negativa (ou purificadora) atua na direção oposta, reduzindo a frequência ou mesmo eliminando mutações deletérias das populações (Hartl e Clark, 1997). Já a seleção balanceadora, que engloba diversos mecanismos de manutenção da diversidade genética favorável, seria a responsável pela manutenção dos polimorfismos nas populações. Dentre os mecanismos através dos quais a seleção balanceadora opera, os mais estudados são a sobredominância (ou vantagem do heterozigoto) e a seleção dependente de frequência (Charlesworth, 2006).

O importante conceito de "carga genética", introduzido por Haldane (1937) e posteriormente elaborado por Muller (1950), foi de extrema importância histórica para a biologia evolutiva. Resumidamente, a ideia é que uma população fica aquém de sua aptidão máxima por dois motivos: (1) pela ocorrência recorrente de mutações deletérias (carga mutacional) e; (2) pela perda de alelos por seleção purificadora (carga selecional). O decréscimo na aptidão máxima de uma população causado por esses dois fenômenos foi chamado de "carga genética" (revisado em Orr, 2005). Nesse sentido, na escola de pensamento "selecionista" chegou-se à conclusão de que a maior parte dos genes eram monomórficos, uma vez que a manutenção de polimorfismos na população, através da seleção 
balanceadora, implicaria em uma alta carga genética (Lewontin, 1974). Esse tipo de argumento, focado na carga genética, foi importante no desenvolvimento da teoria neutra (Nielsen, 2005).

Na década de 60, a descoberta de que os polimorfismos não eram a exceção, mas a regra, levou Kimura $(1968,1983)$ a propor que a maior parte das variantes seriam seletivamente equivalentes. Nesse sentido, grande parte do foco da evolução molecular foi transferido da seleção natural para a deriva genética - o processo através do qual as frequências gênicas mudam nas populações devido a amostragens aleatórias. Quando, por exemplo, um indivíduo de uma população deixa mais descendentes que os outros ao acaso, ocorrerão mudanças nas frequências dos alelos nas populações na próxima geração, por razões não adaptativas e imprevisíveis. Outro exemplo que ilustra os mecanismos da deriva genética é o fenômeno conhecido como "efeito do fundador", em que uma pequena parte de uma população funda uma nova população. Nesse caso, também por uma questão de amostragem, é esperado que a nova população seja diferente da original em termos de presença e frequência de alelos (Campbell, 1996).

A neutralidade descreve a condição em que os locos sob observação não são afetados pela seleção natural. Um ponto importante é que os modelos neutros admitem a possibilidade de intensa seleção purificadora contra mutações fortemente deletérias. A versão original do modelo neutro - o modelo estritamente neutro (Kimura, 1968) - assume que as mutações são ou neutras $(s=0)^{1}$ ou fortemente deletérias $(s=-\infty)$. Esse modelo ainda é muito usado em genética de populações e a maior parte dos estudos direcionados à estimação de parâmetros demográficos o utilizam, implícita ou explicitamente. O modelo clássico de coalescência (Kingman, 2000), por exemplo, é baseado no modelo estritamente neutro, assim como as hipóteses nulas de testes de neutralidade como o $D$ de Tajima e o HKA (Hudson et al., 1987; Nielsen, 2005).

Embora a detecção de seleção purificadora possa ser de grande interesse devido à sua capacidade de ajudar a descobrir regiões ou resíduos de aminoácido de importância funcional, grande atenção tem sido dada à seleção positiva e, em menor escala, à seleção balanceadora. Ambas estão associadas à evolução adaptativa de novas formas e funções (Nielsen, 2005).

Atualmente, o grande desafio dos estudos de evolução molecular tem sido oferecer quantificações e também descrições mais detalhadas sobre os regimes de seleção atuantes sobre regiões específicas do genoma. Qual proporção das mudanças é adaptativa? Qual a distribuição dos coeficientes seletivos? Quais os regimes de seleção específicos que atuam/atuaram sobre determinadas regiões do genoma? Respostas a essas perguntas são, em última instância, respostas às questões do debate entre seleção e neutralidade, e têm sido objeto de muitos estudos (ver, por exemplo, Yang e Nielsen (1998, 2000);

\footnotetext{
${ }^{1} s$, coeficiente de seleção, que pode ser neutro, positivo ou negativo.
} 
Nielsen e Yang, 2003).

\subsection{Assinaturas de seleção e escalas de tempo}

O esforço no sentido de detectar casos de seleção positiva em humanos através do exame individual de genes candidatos, empreendido intensamente ao longo das últimas décadas, resultou em alguns casos bem documentados. Na década de 50, por exemplo, foi percebido que a distribuição geográfica da anemia falciforme estava restrita à África e se correlacionava fortemente com a distribuição da malária naquele continente (Allison, 1954). Essa observação levou à identificação de uma mutação no gene da hemoglobina - B $(H B B)$, responsável pelo fenótipo falciforme das hemácias e alvo da seleção natural por conferir resistência à malária (Currat et al., 2002).

Outro caso bem documentado é o do gene do antígeno Duffy $(D A R C)$, que codifica uma proteína de membrana que o Plasmodium vivax ${ }^{2}$ utiliza para entrar nas hemácias. Uma mutação no promotor desse gene, capaz de interromper a expressão da proteína, confere resistência ao $P$. vivax e é altamente adaptativa em regiões endêmicas da malária (Hamblin et al., 2002).

Outro exemplo amplamente estudado é o da mutação cis-regulatória na região promotora do gene $L C T$ (lactase), que permite que a expressão da lactase persista até a idade adulta. Esse alelo aparentemente foi selecionado fortemente em europeus após a domesticação do gado, entre 2 e 20 mil anos atrás (ver, por exemplo, Bersaglieri et al., 2004 e Sabeti et al., 2006).

Até recentemente, a abordagem baseada em genes candidatos era a única forma prática de encontrar alvos de seleção positiva em humanos (Sabeti et al., 2006). Entretanto, na última década, abordagens baseadas em scans genômicos tornaram-se populares (Bamshad e Wooding,2003; Bustamante et al., 2005; Enard et al., 2010; Fay et al., 2001; Nielsen et al., 2005; Sabeti et al., 2006, 2007). Esses scans só se tornaram possíveis na medida em que sequências genômicas e dados de $\mathrm{SNPs}^{3}$ tornaram-se disponíveis, uma vez que eles vasculham o(s) genoma(s) em busca de certos "padrões" deixados pela seleção natural, conhecidos como assinaturas de seleção.

Um teste estatístico destinado a rejeitar a hipótese de evolução neutra é um teste de neutralidade. Tipicamente, esses testes quantificam algum aspecto de variação que pode ser comparado entre os dados empíricos e os esperados sob um modelo nulo especificado a priori. Quando rejeita-se a hipótese de evolução neutra, esse padrão de variação é considerado uma assinatura de seleção natural.

Pode-se executar testes de neutralidade baseados em genética de populações ou baseados em métodos comparativos. Os testes de neutralidade genético-populacionais são mais adequados para a

\footnotetext{
${ }^{2}$ Das quatro espécies do gênero Plasmodium capazes de provocar malária em humanos, essa é a mais prevalente.

${ }^{3} \mathrm{SNP}$ : single nucleotide polymorphism, polimorfismo de um nucleotídeo.
} 


\begin{tabular}{|c|c|c|c|}
\hline $\begin{array}{c}\text { SELEÇÃO } \\
\text { POSITIVA }\end{array}$ & $\begin{array}{c}\text { SELEÇÃO } \\
\text { BALANCEADORA }\end{array}$ & $\begin{array}{c}\text { ESCALA } \\
\text { DETEMPO }\end{array}$ & EFEITO CONFUNDIDOR \\
\hline $\begin{array}{c}\text { Haplótipos } \\
\text { longos }\end{array}$ & $\begin{array}{c}\text { Haplótipos } \\
\text { longos* }\end{array}$ & $\begin{array}{c}<30 \text { mil } \\
\text { anos }\end{array}$ & Expansão populacional \\
\hline $\begin{array}{c}\text { Aumenta F } \\
\text { entre } \\
\text { populações }\end{array}$ & $\begin{array}{c}\text { Diminui F } \\
\text { entre } \\
\text { populações }\end{array}$ & $\begin{array}{c}50-75 \text { mil } \\
\text { anos }\end{array}$ & Gargalos genéticos \\
\hline $\begin{array}{c}\text { Alta frequência } \\
\text { Alelos com } \\
\text { frequências }\end{array}$ & $\begin{array}{c}<80 \text { mil } \\
\text { anos }\end{array}$ & Subdivisão populacional \\
\hline $\begin{array}{c}\text { Redução da } \\
\text { diversidade } \\
\text { nucleotídica }\end{array}$ & $\begin{array}{c}\text { Aumento da } \\
\text { diversidade } \\
\text { nucleotídica }\end{array}$ & $\begin{array}{c}<250 \text { mil } \\
\text { anos }\end{array}$ & Expansão populacional \\
\hline $\begin{array}{c}\text { Alta proporção } \\
\text { mutações que } \\
\text { alteram funções }\end{array}$ & $\begin{array}{c}\text { Alta proporção } \\
\text { mutações que } \\
\text { alteram funções }\end{array}$ & $\begin{array}{c}\text { Milhares de } \\
\text { anos }\end{array}$ & Robusta a fatores \\
demográficos
\end{tabular}

\section{Métodos Comparativos}

Métodos Populacionais

Figura 1. Algumas assinaturas de seleção positiva. As escalas de tempo referem-se à aplicabilidade de testes de neutralidade baseados em cada assinatura. Figura criada a partir de Bamshad e Wooding (2003) e Nielsen (2005). *A assinatura de haplótipos longos é esperada em casos de seleção dependente de frequência, quando uma mutação sobre rapidamente de frequência (embora o sinal seja mais fraco do que nos casos de seleção positiva), mas não em casos de vantagem do heterozigoto.

deteç̧ão de eventos de seleção ocorridos em escala recente. Já os métodos comparativos, envolvendo dados de mais de uma espécie, são adequados para detectar eventos de seleção ocorridos há mais tempo (Nielsen et al., 2009). A exata abrangência temporal de um teste de neutralidade depende de vários fatores, conforme será discutido.

Os muitos testes estatísticos já propostos para a deteç̧ão de seleção positiva podem ser divididos em cinco grupos, de acordo com a assinatura na qual se baseiam (para uma revisão sobre o assunto, ver Sabeti et al., 2006). Elas são: (1) alta proporção de mutações que alteram funções (seleção positiva e balanceadora); (2) redução da diversidade genética; (3) alta frequência de alelos derivados; (4) diferenças entre populações; (5) haplótipos longos. A figura 1 resume as propriedades gerais de cada uma dessas assinaturas.

De acordo com a teoria neutra (Kimura e Crow, 1963; Kimura, 1968), mutações capazes de alterar a função de uma proteína geralmente são deletérias e, portanto, alvo da seleção purificadora. A evolução adaptativa, todavia, pode levar a um aumento da taxa de fixação dessas mutações e, nesse sentido, a alta proporção de mutações que alteram a função da proteína (em relação às 
mutações sinônimas, que não alteram) é uma plausível assinatura de seleção positiva (Gillespie, 1991) ou balanceadora.

A escala de tempo capaz de gerar essa assinatura é de milhares de anos e testes de neutralidade baseados em abordagens comparativas são ideais para detectar essa assinatura (comparando a taxa de substituições não-sinônimas e sinônimas entre linhagens). Como exemplo temos o teste do $d_{N} / d_{S}$ 4 (Hughes e Nei, 1988,1989b).

Outro padrão de interesse nos scans para genes sob seleção positiva é o da mudança de frequência de polimorfismos neutros ligados ao alelo selecionado, causado pelas varreduras seletivas ${ }^{5}$ (Cai et al., 2009). Esse fenômeno gera uma assinatura, típica de seleção positiva ${ }^{6}$, que consiste em uma baixa diversidade global, com um excesso de alelos raros. Se o tempo desde que ocorreu o evento de seleção positiva sobre uma variante nova e adaptativa for muito longo - como a escala de tempo que, em geral, separa duas espécies - as novas mutações e os eventos de recombinação são capazes de nublar a assinatura. Assim, em humanos, a escala de tempo durante a qual a assinatura persiste é de até cerca de 250 mil anos.

O $D$ de Tajima, o HKA e o $D$ de Fu e Li são os testes mais usados para detectar esse tipo de assinatura (Bamshad e Wooding, 2003) . Uma limitação é que a assinatura pode ser difícil de ser diferenciada de certos efeitos da história demográfica como, por exemplo, a expansão populacional - também capaz de aumentar a fração de alelos raros. Já no caso da seleção balanceadora, o efeito carona gera haplótipos com alta diversidade nucleotídica (Bamshad e Wooding, 2003) . Enquanto que sob ação da seleção positiva o $D$ de Tajima tende a ser negativo em relação ao esperado sob neutralidade (baixa diversidade nucleotídica e excesso de alelos raros), sob seleção balanceadora espera-se um $D$ de Tajima positivo em relação à neutralidade (alta diversidade nucleotídica e excesso de variantes de frequência intermediária) (Bamshad e Wooding, 2003).

Alelos derivados (i.e, não - ancestrais) surgem por novas mutações e, sendo assim, têm frequências tipicamente menores que as dos alelos ancestrais. Se, todavia, uma varredura seletiva ocorrer em função de uma mutação adaptativa, alelos derivados ligados ao alelo adaptativo "pegarão carona" e terão sua frequência aumentada. Como a recombinação e varreduras incompletas são comuns, a seleção positiva cria uma assinatura que consiste de uma região contendo muitos alelos derivados em alta frequência. Em humanos, a escala de tempo durante a qual essa assinatura persiste é de até

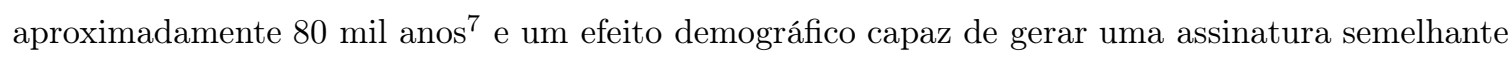

\footnotetext{
${ }^{4}$ Uma explicação mais detalhada sobre essa assinatura será fornecida na subseção 1.3 na página 9

${ }^{5}$ Fenômeno em que uma mutação recém-surgida e altamente adaptativa sobe rapidamente de frequência na população. Nesse processo, a variação neutra em sítios ligados é reduzida.

${ }^{6} \mathrm{O}$ mesmo fenômeno, porém com variantes selecionadas negativamente, é chamado de seleção de fundo (background selection).

${ }^{7}$ Essa estimativa leva em conta a taxa de mutação e o tempo de geração dos humanos.
} 
é a subdivisão populacional (Sabeti et al., 2006). Tanto o excesso de alelos raros quanto a alta frequência de alelos derivados são assinaturas que levam em conta as frequências alélicas, e os testes capazes de detectar essa assinatura são do tipo populacionais.

Outra assinatura que pode ser detectada através de testes de neutralidade baseados em genética de populações é a diferenciação entre populações. Quando populações estão em diferentes ambientes, diferentes alelos podem vir a ser selecionados em cada uma. Se as diferenças de frequências alélicas entre duas populações são muito grandes (alto $F_{S T}{ }^{8}$ ), pode ser um sinal de que o loco sofreu seleção positiva. Como exemplos temos: o gene $L C T$, que apresenta frequências muito diferentes entre europeus e não-europeus e; o gene $D A R C$ do antígeno $D u f f y$, que tem frequências totalmente diferentes na África Subsaariana (onde há alta incidência de malária) do que no resto do mundo. Para que essa assinatura seja gerada, as populações precisam estar pelo menos parcialmente isoladas. Em humanos, esses evento estão praticamente restritos ao período posterior às emigrações humanas para fora da África entre 50 e 75 mil anos atrás (Sabeti et al., 2006). Assim como no caso de outras assinaturas genético-populacionais, os efeitos da história demográfica podem ser muito parecidos com a assinatura da seleção, como é o caso dos efeitos-gargalo ${ }^{9}$, capazes de diferenciar drasticamente as frequências alélicas entre duas populações. Já sob seleção balanceadora espera-se um baixo $F_{S T}$, uma vez que todos os alelos tendem a estar em frequências intermediárias em todas populações (Bamshad e Wooding, 2003) .

Por fim, uma assinatura importante, também causada pelas varreduras seletivas, é o surgimento de haplótipos longos, com alto desequilíbrio de ligação e baixa variação. Haplótipos ${ }^{10}$ longos constituem uma importante assinatura de seleção em pequenas escalas de tempo (menores que 30 mil anos), pois em um período inferior a 30 mil anos, em humanos, a recombinação dificilmente terá tido tempo suficiente para desfazer a estrutura dos haplótipos. A associação com outros alelos levaria à conclusão de se tratar de um alelo recente, ao passo que a alta frequência desse alelo seria um indício de sua ancestralidade. A ocorrência de ambas as características gera uma assinatura típica das varreduras seletivas e não plausíveis em um cenário de neutralidade/deriva (Sabeti et al., 2006).

As abordagens de scans genômicos em busca de regiões genômicas sob seleção positiva, portanto, vasculham o genoma em busca de uma (ou mais) das assinaturas descritas anteriormente. Esses estudos têm documentado não só genes candidatos, mas categorias funcionais candidatas à ação da evolução adaptativa. Muitos desses genes foram atribuídos a categorias de acordo com a classifica-

\footnotetext{
${ }^{8}$ Índice de fixação de Wright: a fração da variabilidade genética total que está distribuída entre as subspopulações de uma população subdividida. Quanto maior o $F_{S T}$, maior a diferenciação entre as subpopulações.

${ }^{9}$ Períodos de tamanho populacional efetivo $\left(N_{e}\right)$ reduzido, seguidos de uma expansão populacional a partir de uma amostra aleatório de sobreviventes. O efeito do fundador, descrito na página 2, é um bom exemplo de efeito gargalo.

${ }^{10}$ Coleção de alelos em uma região cromossômica que tendem a ser herdados conjuntamente nos indivíduos.
} 
ção do banco de dados PANTHER (http://www.pantherdb.org/). As categorias mais enriquecidas para genes selecionados positivamente no scan feito por Harris et al. (2006) foram: "imunidade e defesa", "percepção sensorial" (também encontrados no scan de Haygood et al., 2010 em regiões codificadoras) e "imunidade mediada por células T". "Gametogênese" aparece como quinta categoria mais enriquecida e "espermatogênese e mobilidade" como nona (Harris et al., 2006). Já no scan feito por Bustamante et al. (2005), também usando a classificação do PANTHER, as categorias com maior número de genes com evidências de seleção positiva foram "gametogênse", "percepção sensorial", "apoptose", "transcrição de mRNA", entre outras. Outros scans, como por exemplo o de Enard et al. (2010), utilizam a classificação de processos biológicos chamada GO (Gene Ontology: http://www.geneontology.org/).

Em scans que incluem regiões não-codificadoras - as quais em geral não possuem anotação funcional ${ }^{11}$-, os processos biológicos "neurogênese", "outras atividades neuronais" e "desenvolvimento muscular" (classificação do PANTHER) são enriquecidos com sinais de seleção positiva (Haygood et al., 2010).

Já para a seleção balanceadora não há tantos exemplos bem documentados. Como bem resumiram (Andrés et al., 2009), a atual compreensão acerca da seleção balanceadora é limitada ao estudo de alguns poucos locos identificados através de abordagens de genes candidatos. Alguns deles são: os genes clássicos do MHC de mamíferos (Hughes e Nei, 1988, 1989a; Takahata e Nei, 1990); os genes de resposta a doenças em plantas ("R-genes") (Stahl et al., 1999); o gene da $\beta$-globina em humanos (Pasvol et al., 1978), o loco de determinação sexual em abelhas (Hasselmann et al., 2006), o loco S de auto-incompatibilidade em plantas (Sato et al., 2002) e o gene de forrageamento em Drosophila melanogaster ${ }^{12}$ (Partridge e Sgrò, 1998).

Existem dificuldades associadas à detecção desse tipo de seleção em uma escala genômica. Assim como no caso da seleção positiva, as escalas de tempo dos diferentes tipos de seleção balanceadora afetam as sequências vizinhas (Charlesworth, 2006). As assinaturas genômicas de seleção balanceadora recente (desequilíbrio de ligação estendido) são detectadas por métodos baseados em LD ${ }^{13}$ (Voight et al., 2006) e não são distinguíveis daquelas deixadas por varreduras seletivas positivas incompletas. Já o sinal mais marcante da seleção balanceadora de longo prazo é bastante específico (alta diversidade nucleotídica), assinatura difícil de detectar devido aos efeitos de larga escala da

\footnotetext{
${ }^{11}$ Nesses casos as regiões não-codificadoras são classificadas de acordo com a região codificadora mais próxima, uma vez que regiões codificadoras frequentemente são reguladas por sequências não-codificadoras vizinhas (Haygood et al., 2010).

${ }^{12}$ Alguns casos relatados como sendo exemplos de seleção positiva são controversos, e muitos autores acreditam que possam ser casos de seleção balanceadora, uma vez que algumas assinaturas de seleção positiva são também assinaturas de seleção balanceadora. O gene $H B B$ é um bom exemplo, assim como o caso do MHC humano.

${ }^{13}$ Linkage disequilibrium, ou desequilíbrio de ligação.
} 
recombinação.

Uma abordagem de deteç̧ão de seleção balanceadora consiste em buscar regiões com alta densidade de SNPs. Tais regiões surgem devido a um dos seguintes fatores: (1) alta taxa de mutação; (2) seleção balanceadora e; (3) acaso. Uma busca por tais regiões detectou 16 locos (além de $H L A^{14} \mathrm{e}$ $A B O^{15}$ ) que possuem as mais elevadas densidades de SNPs do genoma humano (Bubb et al., 2006). Entretanto, mesmo esses poucos locos não parecem ter adquirido tais padrões de SNPs devido à ação de seleção balanceadora ao longo de grandes escalas de tempo, como no caso dos genes $H L A$. Os autores sugerem que existe uma falta de regiões fora do $H L A$ que podem ser detectadas como alvos de seleção balanceadora com base no método de detecção de níveis de polimorfismo. Os achados estão de acordo com predições teóricas e resultados experimentais que sugerem que a seleção balanceadora só é capaz de persistir durante milhões de anos e de, além disso, deixar uma assinatura de alto polimorfismo local no genoma (como no caso de $H L A$ ) sob circunstâncias muito especiais (Bubb et al., 2006).

O único scan para alvos de seleção balanceadora propriamente ditos feito até o momento utilizou uma versão modificada do teste HKA (que, normalmente, rejeita a neutralidade na presença de excesso de polimorfismos e divergência) em que o teste este é unilateral (rejeita a neutralidade apenas na presença de excesso de polimorfismos) (Andrés et al., 2009). Essa abordagem possui poder para detectar seleção balanceadora em grandes escalas de tempo. Os autores fizeram uma intersecção entre genes que desviam significativamente na versão modificada do HKA e genes que possuem um excesso de alelos com frequência intermediária e consideraram os genes situados nessa interseção como sendo alvos da seleção balanceadora. Esse estudo gerou uma lista de 60 genes candidatos à a ação da seleção balanceadora no genoma humano, dos quais uma grande proporção está relacionada à imunologia e respostas a patógenos (Andrés et al., 2009).

Em resumo, todas essas assinaturas de seleção refletem o formato das genealogias gênicas: enquanto as varreduras seletivas (assinatura de seleção positiva) resultam em genealogias "rasas" e com poucas mutações, a seleção balanceadora tipicamente gera genealogias profundas nas quais muitas mutações são encontradas em frequências intermediárias e nas quais os alelos persistem mais tempo do que o esperado sob um cenário de neutralidade/deriva (Bamshad e Wooding, 2003). Por isso, a diversidade nulceotídica e a quantidade de alelos segregando um loco sob seleção balanceadora são tipicamente altas, e é possível comparar tal variação com aquela esperada sob o modelo nulo de neutralidade. A figura 6 na página 19 ilustra esse efeito dos diferentes tipos de seleção sobre o

\footnotetext{
${ }^{14}$ Human leucocyte antigen, genes que constituem um subconjunto de genes do MHC (Major histocompatibility complex) humano. Uma discussão acerca das evidências de que os genes $H L A$ têm sido alvos da seleção balanceadora será apresentada na subseção 2.2 na página 17 .

${ }^{15}$ Loco que controla os tipos sanguíneos do sistema ABO.
} 
formato das genealogias gênicas.

\subsection{Mutações sinônimas e não-sinônimas}

No contexto comparativo, uma substituição é uma diferença pontual entre as sequências de duas espécies. Uma substituição de bases no DNA pode ser basicamente de dois tipos: (1) sinônima, quando a substituição não modifica o aminoácido codificado e; (2) não-sinônima, quando a substituição modifica o aminoácido codificado. Ao compararmos duas ou mais sequências, é possível contar o número de substituições de cada tipo e dividir o número de substituições pelo número de sítios, sinônimos ou não-sinônimos, correspondentes. Obtemos, assim, taxas sinônimas e não-sinônimas de substituição $\left(d_{S}\right.$ e $d_{N}$, respectivamente) (Yang, 2006; Gillespie, 1991) ${ }^{16}$.

Em muitos dos scans genômicos mencionados na subseção anterior (p.ex. o de Nielsen et al., 2005) a seleção positiva é inferida quando são detectadas taxas de substituição em sítios nãosinônimos mais elevadas do que sobre sítios sinônimos Harris et al. (2006). De acordo com a teoria neutra (Kimura e Crow, 1963; Kimura, 1968), mutações capazes de alterar a função de uma proteína (mutações não-sinônimas) são geralmente deletérias e, portanto, alvo da seleção purificadora (Kimura, 1968; King e Jukes, 1969). Já as mutações sinônimas, que não alteram a sequência de aminoácidos da proteína, evoluiriam neutramente (embora Resch et al. (2007) tenham destacado o quão disseminados são os casos de seleção positiva atuando sobre mutações sinônimas). A evolução adaptativa, todavia, pode levar a um aumento da taxa de fixação de mutações não-sinônimas $\left(d_{N}\right)$, tornando-a mais alta do que a taxa de substituição sinônima $\left(d_{S}\right)$. Nesse sentido, a razão $d_{N} / d_{S}$, também conhecida como $\omega$, é uma assinatura genética de seleção positiva, conforme mostramos na subseção 1.2 (Nielsen, 2005; Gillespie, 1991).

Moléculas evoluindo de modo neutro (isto é, que não sofrem qualquer pressão seletiva) tendem a acumular ambos os tipos de substituição a taxas semelhantes. Já moléculas sob seleção purificadora tendem a acumular taxas mais altas de mutações sinônimas - dentro da premissa de que a maior parte das mutações não-sinônimas são deletérias (Nielsen, 2005). A comparação entre as taxas de substituição destes dois tipos de mutação fornece uma ferramenta poderosa para entender os mecanismos de evolução molecular das sequências de DNA, bem como para fazer predições acerca da forma de atuação da seleção ao longo do tempo.

Primeiramente proposta por Hill e Hastie (1987), e depois Hughes e Nei (1988), a estimativa da razão $\omega$ é o método mais empregado para detectar efeitos de seleção positiva a partir de dados comparativos de regiões codificadoras (Nielsen, 2005). Quando um loco têm um excesso de

\footnotetext{
${ }^{16}$ Naturalmente, existem mais sítios não-sinônimos do que sinônimos, mas as medidas $d_{N}$ e $d_{S}$, por levarem em conta o número de sítios de cada tipo, eliminam essa ambiguidade (Yang, 2006).
} 
substituições não-sinônimas $(\omega>1)$, infere-se que uma forma de seleção positiva tenha atuado, aumentando variações funcionalmente relevantes (Gillespie, 1991; Kimura, 1983; Ohta, 1995). No caso da seleção balanceadora esse sinal seria semelhante, mas a conjunção de outras assinaturas (excesso de polimorfismos neutros ligados aos locos sob seleção e grande diversidade de alelos nos locos sob seleção balanceadora) permitem diferenciar esses dois tipos de seleção (ver subseção 1.2).

Essa interpretação intuitiva é embasada em argumentos teóricos acerca da relação entre a estatística $\omega$ e a pressão seletiva subjacente dentro de um modelo de Wright-Fisher (Nielsen e Yang, 2003; Kryazhimskiy e Plotkin, 2008).

Embora formulado originalmente sem uma consideração direta do aspecto populacional, o modelo de Markov de Nielsen e Yang (2003) do processo de substituição em um sítio pode ser derivado como o limite de um processo populacional de Wright-Fisher subjacente. Essa derivação assume que: (1) os sítios são independentes uns dos outros e; (2) que nunca há mais do que dois alelos (para um dado sítio) segregando em uma população. A segunda premissa é justificada se assumirmos que a taxa de mutação é suficientemente baixa para que um alelo sempre atinja a fixação ou seja extinto antes que um novo alelo surja. Aceitando-se essas premissas, a taxa de fixação de novas mutações com coeficiente de seleção $s$ é dada pelo produto da taxa de mutação (dimensionada pelo tamanho populacional ${ }^{17}$ ) pela probabilidade de fixação (Kryazhimskiy e Plotkin, 2008):

$$
\mu N \frac{2 s}{1-e^{-2 N s}}(1)
$$

Taxas desse tipo são usadas como taxas instantâneas de transição nos modelos de substituição baseados em cadeias de Markov. Se assumirmos que as substituições sinônimas são neutras e que todas as não-sinônimas têm um coeficiente de seleção $s$, então a razão entre as taxas não-sinônima e sinônima, $\omega$, é dada por:

$$
\omega(\gamma)=\frac{2 \gamma}{1-e^{-2 \gamma}}(2)
$$

, onde $\gamma=N s$. A última equação estabelece uma importante relação entre $\omega$, a razão de taxas de substituição ao longo de linhagens independentes, e $\gamma$, o coeficiente de seleção subjacente em um modelo de Wright-Fisher. A equação deixa claro, também, que só se espera $\omega>1$ quando existe seleção positiva sobre mutações não-sinônimas (ou seja, $\gamma>1$ ) e $\omega<1$ somente quando $\gamma<1$ (Kryazhimskiy e Plotkin, 2008).

\footnotetext{
${ }^{17}$ Taxa de mutação dimensionada pelo tamanho populacional: $N \mu$, onde $N$ é o tamanho efetivo da população e $\mu$ é a taxa de mutação.
} 


\subsection{Vantagens da estimativa $\omega$ como assinatura de seleção natural}

Métodos de deteç̧ão de seleção baseados em frequencias alélicas dentro de populações são pouco robustos frente a fatores demográficos, como, por exemplo, mudanças no tamanho populacional efetivo. Já os métodos baseados na comparação de taxas de substituição não-sinônimas $\left(d_{N}\right)$ e sinônimas $\left(d_{S}\right)$ são bastante robustos, uma vez que assume-se que tais sítios estão intercalados nas regiões do genoma sob estudo (e portanto partilham a mesma história demográfica). Além disso, $\omega$ é uma medida direta dos efeitos da seleção sobre uma proteína. A vantagem desta assinatura é que ela foca o gene em questão, eliminando ambiguidades acerca do alvo da seleção e é uma muito eficaz para detectar seleção em grupos de genes (e também em grupos de códons de um gene). Essa propriedade diminui a variância entre os sítios no que diz respeito à história demográfica afinal, diferentes sítios, quando distantes, podem experimentar diferentes histórias genealógicas, introduzindo uma outra fonte de variância (i.e, incertezas) nas análises (Nielsen et al., 2009).

Por outro lado, os testes baseados em $\omega$ requerem múltiplas substituições para que $\omega$ possar ser significativamente maior que 1: o critério de $\omega>1$ para que genes estejam sob seleção positiva é muito rigoroso. Partindo da premissa de que a maior parte das mutações não-sinônimas são deletérias (Kimura e Crow, 1963; Kimura, 1968) o critério não é atendido, muitas vezes, quando genes inteiros são analisados. Isso ocorre porque geralmente apenas alguns códons estão sob seleção positiva, enquanto a maior parte das mutações não-sinônimas são deletérias e, portanto, estão sob seleção purificadora. No scan feito por Nielsen et al. (2005), por exemplo, 733 genes com $d_{N} / d_{S}>1$ foram encontrados,mas apenas um subconjunto de 35 apresentou um valor de $d_{N} / d_{S}$ significativamente maior que 1, indicando seleção positiva na história do gene.

Por isso, há algum tempo convencionou-se analisar subconjuntos de códons em busca de seleção, seja através de uma base de dados mais restrita (ver, por exemplo, Hughes e Nei, 1988, 1989b) ou através de modelos que estimam diferentes valores de $\omega$ para os códons ${ }^{18}$, tornando possível inferir quais deles estão sob seleção positiva.

\subsection{Escalas de tempo: uma possível limitação da ferramenta $d_{N} / d_{S}$ ?}

A razão $\omega$ foi originalmente desenvolvida para análises de sequências de diferentes espécies. Nesses casos, as diferenças entre as sequências representam eventos de substituição ocorridos ao longo de cada linhagem. Além disso, implícita nessa premissa está a noção de que a divergência entre as sequências analisadas não é baixa.

\footnotetext{
${ }^{18}$ Eles estão disponíveis, por exemplo, no pacote PAML, sob o nome de "site models" e serão discutidos mais adiante, na subseção 5.3 (página 37).
} 
Os programas usados para estimação dessa razão adotam os modelos que foram desenvolvidos para a situação em que as diferenças observadas são substituições. Essa premissa é adotada pois a razão envolve taxas de substituição que surgiram e foram fixadas em cada espécie e, por definição, não descreve o que está ocorrendo dentro de uma espécie.

Para linhagens que divergiram há muito tempo, o problema de muitas substituições ocorrendo no mesmo sítio complica o cálculo de $d_{N}$ e $d_{S}$, mas muito esforço já foi feito no sentido de minimizar esse problema (ver, por exemplo, Nei e Gojobori (1986) e Yang e Nielsen (2000) para modelos de substituição que buscam corrigir para a saturação de substituições ao longo de uma linhagem). Muito menos atenção foi dada, até recentemente, para o problema de se comparar sequências com baixo grau de divergência (Kryazhimskiy e Plotkin, 2008).

Mesmo sabendo-se pouco sobre o comportamento da razão $d_{N} / d_{S}$ para baixos graus de divergência entre sequências, o método é frequentemente usado para dados de sequência que podem representar amostras de uma só população, como é o caso dos estudos de seleção natural em microorganismos (Crandall et al., 1999). Entretanto, em tais casos, as diferenças entre sequências não representam eventos de fixação ao longo de linhagens divergentes, mas sim polimorfismos que estão segregando em uma única população.

Um estudo mostrou que, nesses casos, a relação entre $d_{N} / d_{S}$ e seleção não é regida por uma função monotônica ${ }^{19}$ e, portanto, pode ser impossível inferir pressões seletivas a partir de $d_{N} / d_{S}$ (Kryazhimskiy e Plotkin, 2008). Uma razão $d_{N} / d_{S}=0.1$ (encontrada frequentemente na prática) seria interpretada como sinal de seleção purificadora fraca, no caso das linhagens analisadas serem divergentes, ao passo que, em amostras populacionais, tal valor seria um sinal de seleção purificadora de grande intensidade (ver figura 2 na página seguinte)(Kryazhimskiy e Plotkin, 2008). Em estudos com microorganismos, torna-se um problema comum, uma vez que as linhagens comparadas geralmente são muito próximas.

Rocha et al. (2006) mostraram que, quando linhagens de uma mesma espécie (ou mesmo espécies muito próximas) estão sendo comparadas com o método do $d_{N} / d_{S}$, um novo parâmetro, de tempo de divergência entre as linhagens/espécies, deve ser levado em conta nas inferências de seleção. Os autores mostraram que, para tempos de divergência baixos, existe uma tendência para valores altos de $d_{N} / d_{S}$, o que pode ser interpretado como consequência da remoção pouco eficaz, em pequenas escalas de tempo, de mutações não-sinônimas levemente deletérias.

As duas limitações discutidas - amostras populacionais e linhagens com baixo tempo de divergência - estão relacionadas à teoria por trás da utilização da razão $\omega$ para inferências de seleção e às

\footnotetext{
${ }^{19}$ Uma função $f$ é dita monotônica, ou monótona, se puder ser classificada como crescente, estritamente crescente, decrescente ou estritamente decrescente.
} 


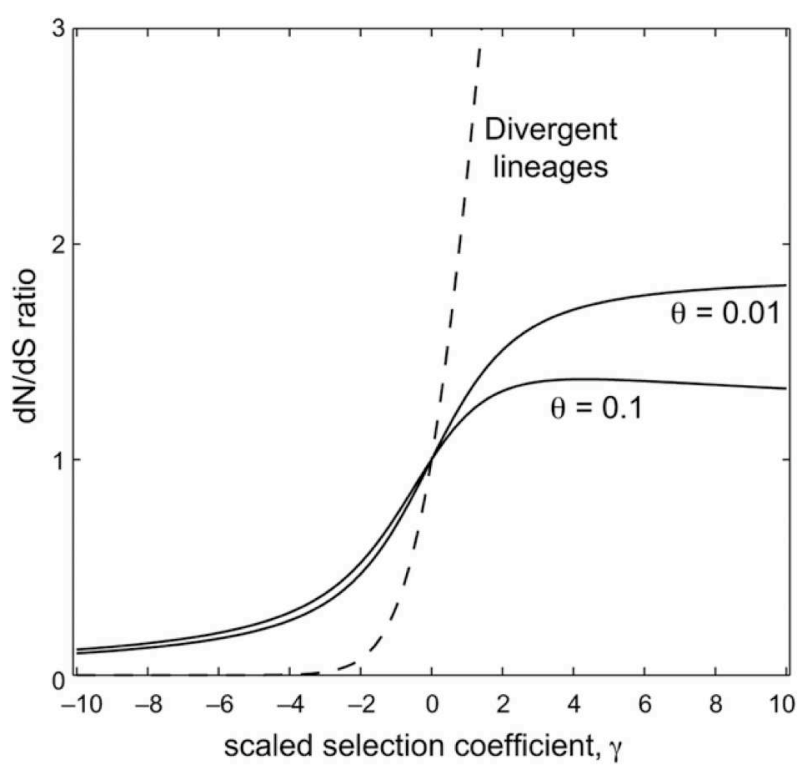

Figura 2. Relação entre o coeficiente seletivo dimensionado pelo o tamanho populacional, $\gamma$, e a razão $d_{N} / d_{S}$ esperada. A linha pontilhada mostra a razão $d_{N} / d_{S}$ esperada para amostras de linhagens divergentes, dada na equação 1 na página 10. As linhas contínuas mostram a razão $d_{N} / d_{S}$ esperada para amostras intrapopulacionais. $\theta=2 \gamma$. Figura adaptada de Kryazhimskiy e Plotkin (2008).

escalas de tempo. Ao longo de escalas de tempo longas, $\omega$ é uma ferramenta robusta e informativa para medidas de evolução adaptativa em regiões codificadoras de proteínas. Na prática, $\omega$ pode ser estimado a partir dos dados usando um pacote computacional como, por exemplo, o PAML (Yang, 2007). O modelo markoviano subjacente ao cálculo de $\omega$ usado por esse programa (e também por outros) ignora explicitamente os polimorfismos segregantes de uma população e trata cada espécie divergente como uma única sequência, assumindo que eventos de fixação ocorrem instantaneamente. Tais premissas são perfeitamente razoáveis dada a longa escala de tempo de diversificação das linhagens (i.e, espécies). Em tal escala de tempo, os eventos de substituição são, de fato, efetivamente instantâneos (Kryazhimskiy e Plotkin, 2008).

Portanto, apesar de originalmente desenvolvidos para os métodos comparativos de deteç̧ão de assinaturas de seleção, abordagens baseadas em $\omega$ têm sido, com o crescente aumento de disponibilidade de sequências codificadoras completas, amplamente empregados na compreensão dos mecanismos de seleção dentro de uma única espécie (Yang e Nielsen, 1998; Nielsen e Yang, 2003; Meyer, 2006a). Não se trata, nesse caso, nem de uma abordagem populacional - pois os dados de frequências alélicas não são utilizados -, nem comparativa, propriamente dita - pois apenas as taxas intra-específicas são analisadas -. Trata-se, sim, de uma perspectiva "comparativa intra-específica". As limitações discutidas aqui, contudo, restringem-se a certos tipos de estudos cujas amostras muitas vezes provêm de uma mesma população ou de linhagens de espécies bacterianas. A importância 
de se considerar o efeito intrínseco de aumento de $\omega$ para sequências com baixa divergência, todavia, deve ser mantida em mente, e será abordada nessa dissertação através do uso de uma simulação. 


\section{Seleção sobre genes $H L A$}

\subsection{Estrutura e função do MHC}

Os genes do MHC (Major Histocompatibility Complex) constituem um sistema genético muito estudado devido à sua influência em vários aspectos importantes da saúde humana, incluindo resistência a doenças infecciosas, auto-imunidade, compatibilidade de transplantes de tecidos, abortos espontâneos, preferências de odor, escolha de parceiros para cópula, entre outros (Bernatchez e Landry, 2003; Penn e Ilmonen, 2005). O MHC em humanos é uma região com cerca de 4 milhões de pares de bases, o que corresponde a cerca de $0.1 \%$ do genoma humano, e contém mais de 200 loci codificantes (revisado em Penn e Ilmonen, 2005).

Os genes HLA constituem um subconjunto de genes do MHC humano e estão localizados no braço curto do cromossomo 6 (Abbas et al., 2000). Os genes $H L A$ são divididos em dois grupos principais: $H L A$ de classe I - subdividido em genes clássicos $(H L A-A, H L A-B$ e $H L A-C)$ e nãoclássicos $(H L A-E, H L A-F$ e $H L A-G)$ - e $H L A$ de classe II (HLA-DRA, HLA-DRB, HLA-DQA, $H L A-D Q B, H L A-D P A$ e $H L A-D P B)$. Os genes clássicos são expressos na maior parte das células somáticas e desempenham papel central no processo de resposta imune adaptativa, capturando e apresentando peptídeos na superfície celular (Klein e Sato, 2000). A figura 3 mostra a localização dos diversos genes $H L A$.

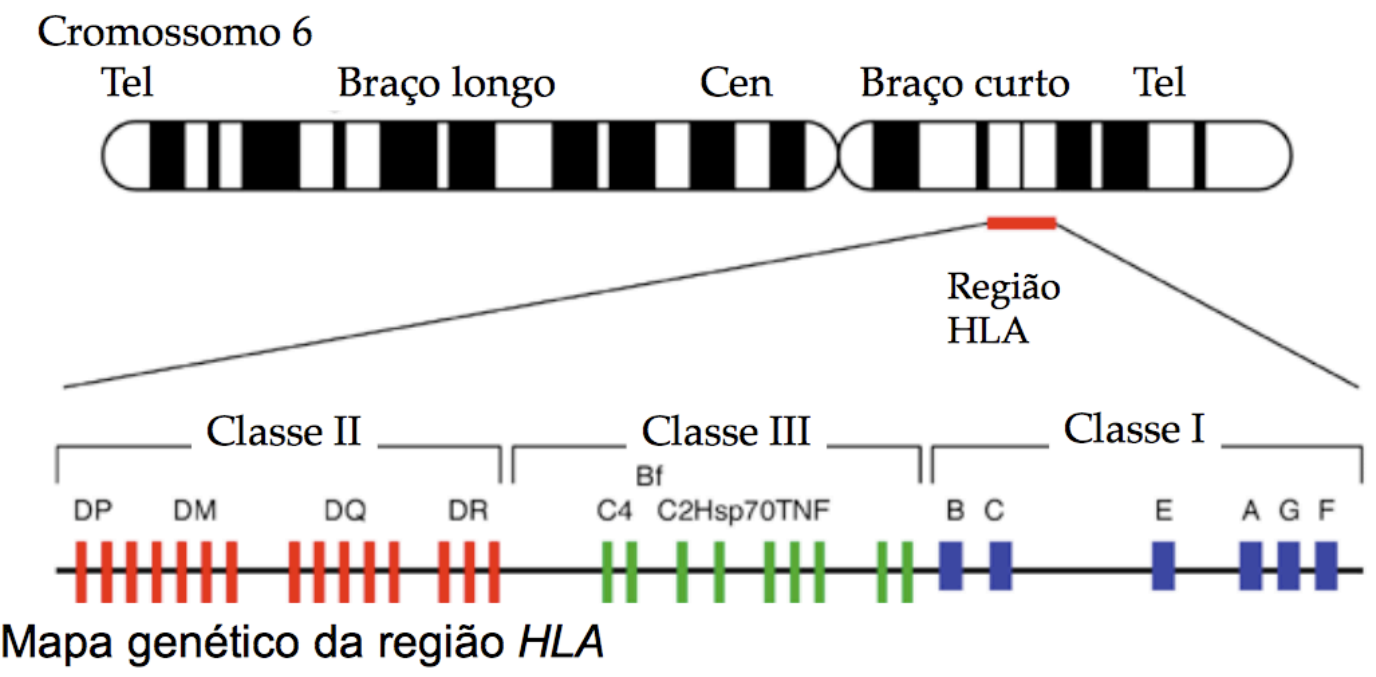

Figura 3. Mapa genético da região $\boldsymbol{H L A}$. Figura esquemática mostrando o cromossomo 6 , a região $H L A$ e os genes $H L A$ de classe I, II e III. Cen, contrômero; tel, telômero. Expert Reviews in Molecular Medicine(C)2003 Cambridge University Press

A molécula de classe I consiste de uma cadeia $\alpha$ (codificada pelos genes de classe I) e de uma 


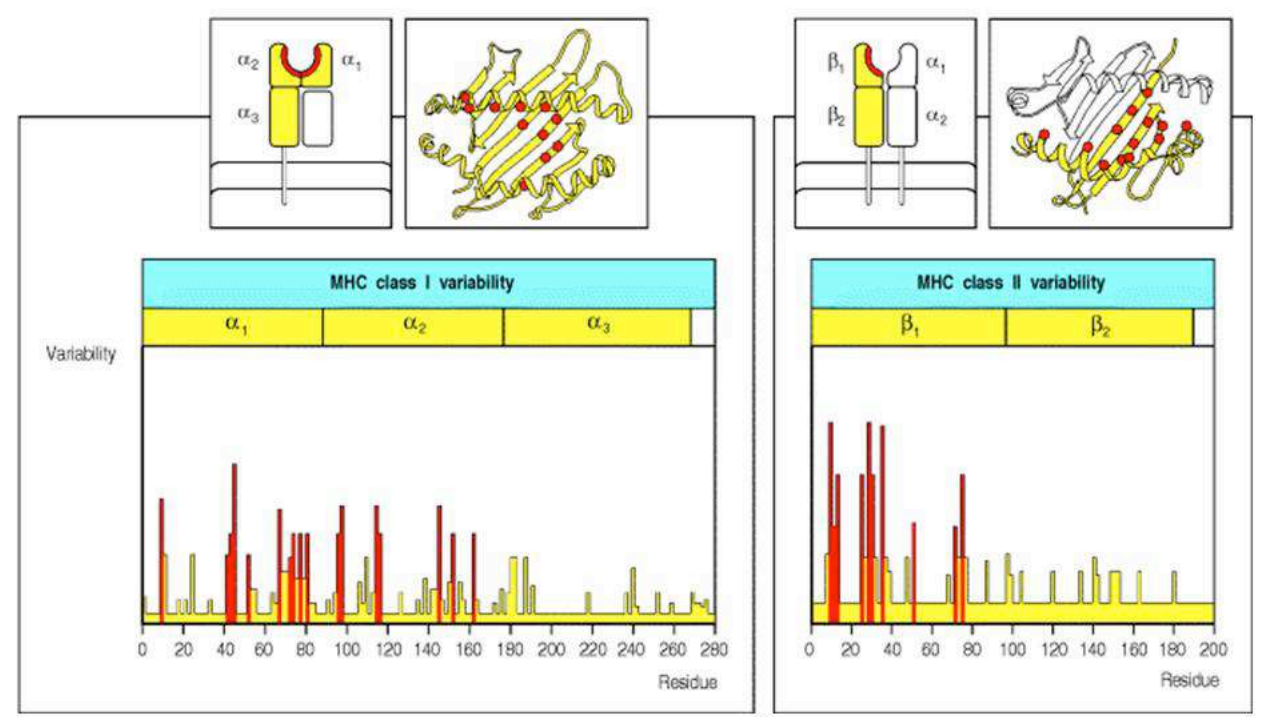

Figura 4. Estrutura molecular e diversidade genética das moléculas MHC. A figura corresponde à distribuição da diversidade nas regiões gênicas correspondentes aos diferentes domínios das moléculas. A medida de diversidade utilizada para gerar os gráficos foi a taxa de heterozigose. Adaptada a partir de Janeway et al. (2004). A fenda apresentadora de antígenos está marcada em vermelho e corresponde aos domínios $\alpha_{1}$ e $\alpha_{2}$ nas moléculas de classe I, e domínio $\beta_{1}$ nas moléculas de classe II.

molécula de $\beta$-2-microglobulina $\left(\beta_{2} m\right)$ (ver figura 4). A fenda do domínio extracelular da cadeia $\alpha$ abriga peptídeos de origem citosólica (8-11 aminoácidos de comprimento), que são processados no interior da célula e apresentados na superfície celular através da molécula de MHC (Abbas et al., 2000). Os genes não-clássicos de classe I têm um menor nível de polimorfismo e de expressão na superfície celular do que os genes clássicos (Robinson et al., 2003).

Já a molécula de MHC de classe II consiste de uma cadeia $\alpha$ e uma cadeia $\beta$, não-covalentemente associadas, codificadas por dois genes distintos (Klein et al., 1986). Os genes de classe II são normalmente expressos por células B, células T ativadas, macrófagos, células dendríticas e células tímicas epiteliais (Klein et al., 1986). A fenda formada pelas cadeias $\alpha$ e $\beta$ abriga peptídeos antigênicos de origem extra-celular de 13-25 aminoácidos de comprimento que, se forem reconhecidos como nãopróprios, induzem células T CD4+ (helper) a produzir anticorpos e estimulam macrófagos através da secreção de citocinas (Abbas et al., 2000).

A região da molécula de MHC à qual o antígeno é ligado é conhecida como sítio de reconhecimento antígeno (ARS - antigen recognition site), também chamada de região de ligação do peptídeo 
(PBR - peptide binding region). Em moléculas de classe I, a fenda apresentadora de peptídeo corresponde aos domínios $\alpha_{1}$ e $\alpha_{2}$ nas moléculas de classe I, e ao domínio $\beta_{1}$ nas moléculas de classe II (Hughes e Nei, 1988; Bjorkman et al., 1987). Os códons ARS são um subconjunto dos códons que codificam os resíduos que formam essas fendas. Para os alelos de classe I, a primeira classificação de códons ARS, baseada na estrutura cristalográfica do complexo MHC-peptídeo foi a de Bjorkman et al. (1987). Anos mais tarde, Chelvanayagam (1996) propos uma classificação também baseada na estrutura da molécula, mas levando em conta, adicionalmente, a "vizinhança" dos resíduos que parecem ser os responsáveis pela apresentação dos peptídeos antigênicos. Como essa região determina a especificidade da molécula de MHC, supôs -se que a seleção positiva sobre os genes que codificam a molécula de MHC estaria direcionada para a porção do gene correspondente à ARS. Hughes e Nei (1988) foram os primeiros a encontrar evidências a favor dessa hipótese, encontrando taxas de substituição não-sinônimas maiores que as taxas sinônimas para os códons ARS de $H L A-A,-B$ e - $C$, conforme veremos em maior detalhe na próxima subseção.

\subsection{Seleção balanceadora em $H L A$}

Uma característica marcante dos genes do MHC envolvidos na apresentação de peptídeos é o seu alto grau de polimorfismo. A maior parte dos genes considerados polimórficos no genoma humano tem substancialmente menos alelos que os locos $H L A$. O polimorfismo dos locos $H L A$ na população é extremamente alto: para alguns locos, centenas de alelos já foram identificados. O loco $H L A-B$, por exemplo, tinha, até recentemente, 1799 alelos descritos (IMGT ${ }^{20}$, Julho de 2010). Mais importante, quando o teste de Ewens-Waterson (Watterson et al., 1978) é aplicado ao $H L A$, a homozigose nas populações tende a ser bem menor do que a esperada sob neutralidade ${ }^{21}$ (Hedrick e Thomson, 1983; Klitz et al., 1986; Meyer et al., 2006). O fato de a taxa de heterozigose ser maior do que a esperada sob equilíbrio condicionada ao número de alelos presentes na população indica que muitos alelos estão com frequencias intermediárias - uma clássica assinatura de seleção balanceadora, apresentada anteriormente.

A divergência nucleotídica também é marcante: alelos de $H L A-A$, por exemplo, diferem, em média, em $3.2 \%$ de seus sítios - mais que uma ordem de grandeza maior do que a média genômica em humanos (Meyer e Thomson, 2001). Uma vez que as taxas de mutação experimentadas pelos genes $H L A$ são similares àquelas de outros genes nucleares (Klein, 1986; Satta et al., 1993) e que os

\footnotetext{
${ }^{20}$ The international IMmunoGeneTics information system: http://www.ebi.ac.uk/imgt/

${ }^{21} \mathrm{O}$ Ewens-Waterson é um teste de neutralidade que calcula o desvio entre a heterozigose observada numa dada população e aquela esperada sob neutralidade. Ele relaciona o número de alelos observados em uma população com a heterozigose associada. Se a heterozigose observada é maior do que a esperada sob neutralidade, a hipótese nula é rejeitada.
} 


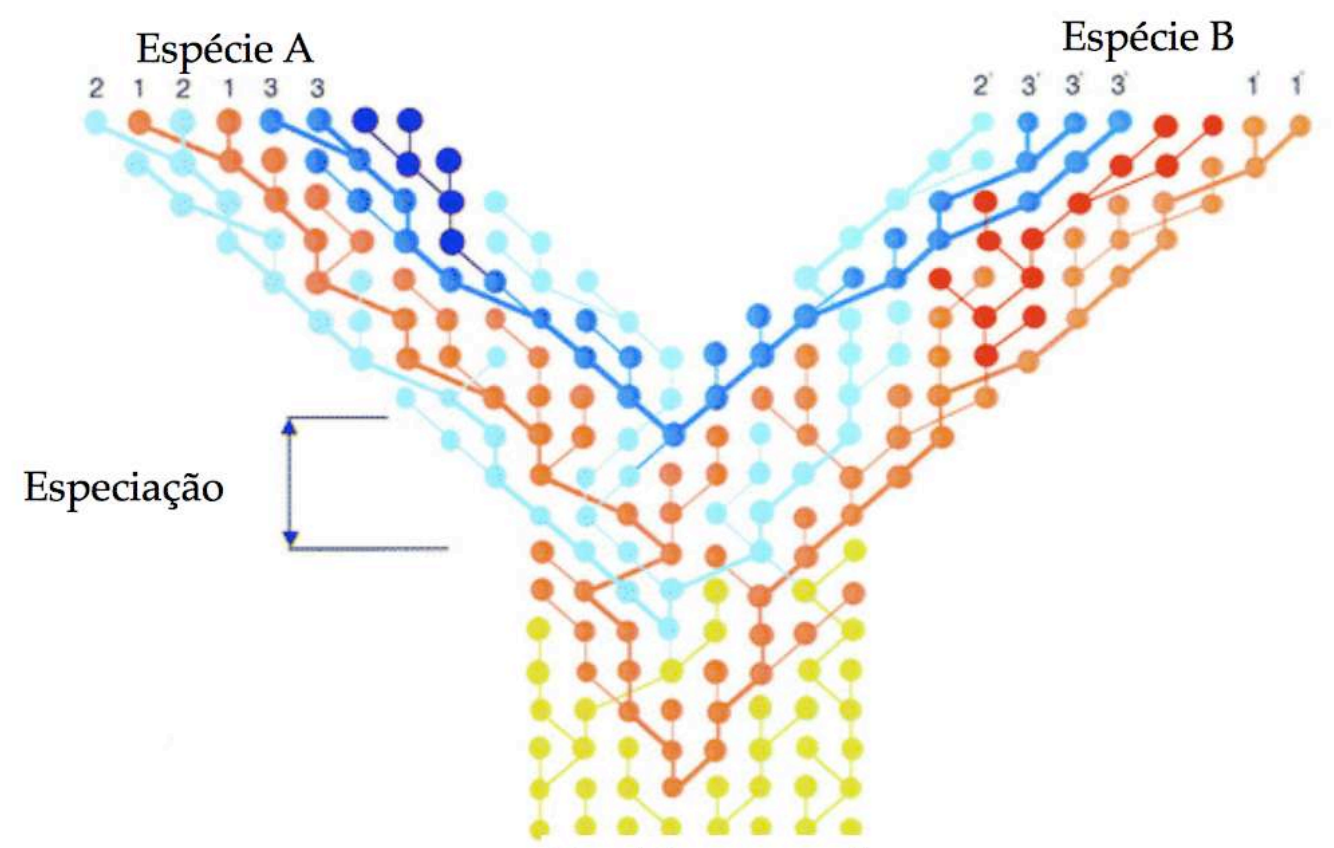

Espécie ancestral

Figura 5. Polimorfismos trans-específicos. Os números referem-se a polimorfismos presentes em cada uma das espécies. O polimorfismo laranja é trans-específico, pois sua coalescência é mais antiga do que o evento de especiação. Figura adaptada de Klein et al. (1998).

genes $H L A$ experimentaram os mesmos tamanhos efetivos que os demais genes nucleares, a maior variação nos genes $H L A$ sugere que uma forma de seleção natural que resulte em alta variabilidade seja responsável por tal padrão.

A grande diferenciação entre alelos $H L A$ é uma evidência de que eles são "antigos" (i.e, persistem por mais tempo) quando comparados a alelos neutros. Outra evidência do quão antigos são os alelos de genes do MHC é que muitos deles são compartilhados entre espécies que divergiram há muito tempo, um fenômeno conhecido como polimorfismo trans-específico (Klein e Figueroa, 1986; Klein et al., 1993; Mayer et al., 1988; McConnell et al., 1988; Lawlor et al., 1988; Klein et al., 1993). A figura 5 ilustra o que são polimorfismos trans-específicos.

A ocorrência de muitos polimorfismos trans-específicos no MHC resulta em topologias e tempos de coalescência bastante diferentes daqueles observados para genealogias de genes que estão evoluindo neutramente (ver figura 6 na página seguinte, que compara os tempos de coalescência 


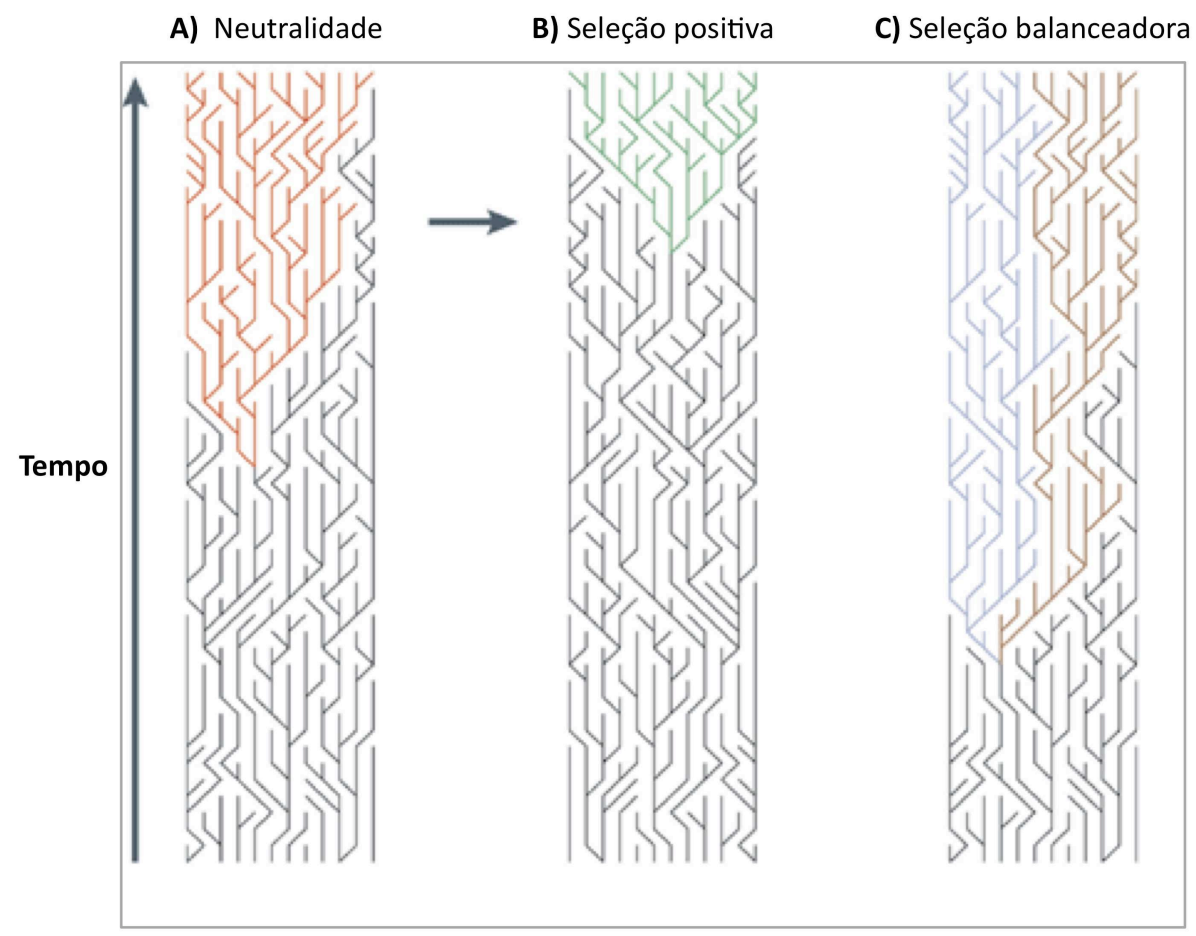

Figura 6. Efeitos da seleção natural sobre as genealogias gênicas e frequências alélicas. Cada figura representa a genalogia completa para uma população de 12 indivíduos haploides. As linhas coloridas correspondem a todos os descendentes que herdaram um alelo neutro ou afetado pela seleeão natural. A) trajetória de um alelo neutro (vermelho) até atingir a fixação ( $4 N_{e}$ gerações); $B$ ) a genealogia de um alelo (verde) que chega à fixação mais rapidamente do que um alelo neutro, por estar sujeito à seleção positiva (rever explicação sobre varreduras seletivas na página $5 ; C$ ) a genealogia de dois alelos (azul e dourado) sob seleção balanceadora, que não são fixados nem eliminados. No caso da seleção balanceadora, o tempo de coalescência é maior do que o esperado sob neutralidade, uma vez que existe pressão seletiva para a manutenção dos polimorfismos. Figura adaptada a partir de Bamshad e Wooding (2003).

para mutações sujeitàs à seleção positiva, balanceadora e evolução neutra) (Takahata e Nei, 1990; Takahata, 1990a; Lawlor et al., 1988; Bamshad e Wooding, 2003). A seleção balanceadora pode aumentar a variação mantendo alelos numa população por mais tempo do que seria esperado sob a neutralidade, permitindo que acumulem mais diferenças do que alelos neutros (Takahata, 1990).

Todos os resultados discutidos previamente (alta diversidade, grande diferenciação entre alelos e a existência de polimorfismos trans-específicos) indicam que algum tipo de seleção balanceadora atuou sobre os genes das moléculas $\mathrm{MHC}^{22}$, pois esses padrões não são esperados para genes evoluindo de modo neutro. Dois modelos seletivos podem explicar a manutenção desse polimorfismo: (1) seleção favorecendo hospedeiros heterozigotos para locos MHC (primeiramente proposta por

\footnotetext{
${ }^{22}$ Muitos desses estudos investigaram genes do MHC em geral, e muitas vezes não apenas de humanos. Por isso o termo " $H L A$ " não foi usado aqui.
} 
Doherty e Zinkernagel (1975)) e; (2) seleção a favor de alelos raros dos genes MHC através da co-evolução entre patógenos e hospedeiro, ou seleção dependente de frequência direcionada por patógenos (primeiramente proposta por Clarke e Kirby (1966)).

A explicação baseada na seleção vantagem do heterozigoto nasceu da percepção de que, devido à alta diversidade de moléculas de MHC na população, diferentes indivíduos tipicamente montam uma resposta imune contra diferentes subconjuntos de peptídeos de um dado patógeno (Barouch et al., 1995). A partir de 1975, quando Doherty e Zinkernagel descobriram o fenômeno da restrição ao MHC, muitos experimentos mostraram que uma dada célula T só reconhece peptídeos virais (fragmentos curtos de proteínas virais) quando eles estão ligados a uma molécula de MHC específica. Foi então aventado que, por serem necessárias combinações específicas de MHC-peptídeo para desencadear uma resposta imune, indivíduos heterozigotos em locos MHC conseguiriam se defender com maior eficiência de infecções através de respostas imunes efetivas contra uma maior variedade de patógenos. Essa idéia de vantagem do heterozigoto (ou sobredominância) ainda é central nas pesquisas que dizem respeito ao MHC.

Por fim, conforme dito anteriormente, há informação sobre o papel da seleção natural na evolução de genes MHC nas taxas de substituição sinônimas e não-sinônimas (Kimura, 1980; Gillespie, 1991; Ohta, 1995). Hughes e Nei (1988) encontraram taxas de substituição não-sinônimas elevadas em códons ARS (para $H L A-A,-B$ e $-C$ ) e atribuíram tal padrão à seleção a favor do heterozigoto (operante sobre ARS), que favoreceria variantes alélicas com novas especificidades - e, portanto, com capacidade para responder a novos patógenos.

Outros estudos apoiam a hipótese de que a seleção dependente de frequência seria a grande responsável pelos padrões de diversidade encontrados em genes de moléculas do MHC. Simulações feitas por Borghans et al. (2004), por exemplo, mostram que o grau de polimorfismo do MHC que surge sob a co-evolução patógeno-hospedeiro é muito maior do que meramente sob vantagem do heterozigoto, e é proporcional ao tamanho da população hospedeira. Eles concluíram que a co-evolução patógeno-hospedeiro (seleção dependente de frequência) é capaz de justificar graus verossímeis de polimorfismo do MHC, enquanto a vantagem do heterozigoto isoladamente não.

A ocorrência de seleção dependente de frequência e seleção a favor do heterozigoto dá origem a um equilíbrio dinâmico com frequências alélicas/haplotípicas flutuantes. Outros fatores, tais como isolamento geográfico ou social e pressões seletivas fortes movidas por infecções severas podem influenciar o grau de polimorfismo do MHC que surge numa população (Hill et al., 1991; Hedrick, 2002). Devido às diferenças de aptidão entre os alelos do MHC, a vantagem do heterozigoto explicaria apenas uma porção modesta do polimorfismo encontrado no MHC, mesmo em populações hospedeiras 
grandes (ver Trachtenberg et al. (2003) e De Boer et al. (2004)).

Na subseção 1.1 mostramos que, dentro da escola de pensamento essencialmente "evolucionista", a seleção balanceadora explicaria altos níveis de variação genética nas populações. A teoria neutra da evolução molecular forneceu uma outra explicação para a alta frequência de polimorfismos genéticos nos genomas, mas deixou em aberto a seguinte questão: quão frequente é a seleção balanceadora? (Asthana et al., 2005).

Dentre os exemplos de seleção balanceadora citados anteriormente (página 7), o $H L A$ tornouse um sistema bastante investigado e compreendido, principalmente pela sua grande importância biológica. Muitas doenças inflamatórias e autoimunes estão relacionadas aos genes de $H L A$ de classe I e II (Becker et al., 1998). É o caso, por exemplo, da associação entre a taxa de homozigose dos genes $H L A$ de classe I e uma progressão mais rápida para a AIDS em indivíduos caucasóides e afroamericanos (Carrington et al., 1999). Outro exemplo bem documentado é que em indivíduos infectados com hepatite $\mathrm{C}(\mathrm{HCV})$, aqueles heterozigotos para $H L A-D R B 1$ são menos frequentes do que os homozigotos (Hraber et al., 2007), indicando um papel da vantagem do heterozigoto na proteção contra o vírus (ver Hill (1998) para uma revisão sobre a base imunogenética de algumas doenças infecciosas).

Os genes $H L A$ sofreram seleção balanceadora ao longo de uma escala de tempo bastante longa, hipótese corroborada pela presença de polimorfismos trans-específicos nesses locos, pela longa permanência dos alelos (maior tempo de coalescência do que outras regiões do genoma ) e pela alta diversidade nos sítios que sofreram seleção e também nos sítios neutros ligados aos mesmos (Charlesworth, 2006). Asthana et al. (2005) argumentam que, com exceção dos genes do MHC, para os quais a existência de polimorfismos tran-específicos já foi amplamente discutida, existe pouco poder estatístico para detectar seleção balanceadora ocorrida em grandes escalas de tempo. O sinal da seleção balanceadora nessa escala de tempo é claro (excesso de polimorfismos na vizinhança do gene selecionado) mas difícil de ser detectado devido aos efeito de larga escala da recombinação (Andrés et al., 2009).

Concluindo, a seleção em $H L A$ é bem documentada, em particular para escalas de tempo longas. Há poucos genes com evidência de seleção balanceadora tão extrema, e com bases mecanísticas para explicar a seleção tão claras. Entretanto, como veremos a seguir, mesmo para os genes clássicos do MHC há questões que permanecem em aberto sobre o modo de ação da seleção balanceadora. 


\subsection{Linhagens alélicas em $H L A$}

Linhagens alélicas em $H L A$ foram originalmente definidas como grupos de alelos com propriedades imunológicas compartilhadas (também conhecidas como grupos serológicos) (Takahata e Satta, 1998b). Na prática, entretanto, muitos alelos foram identificados com o uso de métodos de biologia molecular e não há informação sobre seus padrões de reação serológica (Choi et al., 2011). Esses alelos foram, em sua maioria, nomeados com base em identidade de sequência (Marsh et al., 2005) e alelos de linhagens diferentes têm pelo menos uma substituição em um códon ARS. Sendo assim, alelos de uma mesma linhagem são filogeneticamente mais próximos do que alelos de linhagens distintas. A figura 7 na próxima página mostra um exemplo de uma árvore parcial (contendo uma fração dos alelos) de $H L A-B$, com os alelos coloridos de acordo com suas respectivas linhagens.

Historicamente, os dois primeiros dígitos do nome do alelo de $H L A$ representam sua especificidade serológica ou linhagem (Takahata e Satta, 1998b). Dessa forma, a nomenclatura hoje em dia reflete muito mais a homologia de sequências (o "parentesco" filogenético) do que as especificidades serológicas dos alelos, embora exista alta probabilidade de que alelos com sequências semelhantes sejam funcionalmente correlacionados (Choi et al., 2011).

A operação dos regimes seletivos apresentados anteriormente resulta em um padrão de diversidade atípico para genes do MHC, em relação ao restante do genoma. Conforme discutido anteriormente, as genealogias dos genes MHC apresentam duas particularidades: são profundas (pois os alelos são mais antigos - e, portanto, diferenciados - do que o esperado para genes neutros) e sua diferenciação nos códons ARS apresenta um excesso de mutações não-sinônimas. Apesar dessas evidências, uma questão ainda não foi investigada. Não se sabe sobre quais alvos foi direcionada a seleção balanceadora sobre os genes $H L A$. Em outras palavras, as evidências de seleção (sob a forma de $d_{N}>d_{S}$ para códons ARS) podem resultar da ação da seleção: (a) ao longo de todo o processo de diversificação alélica (i.e., entre e dentro das linhagens, sendo os alelos os alvos da seleção) ou; (b) apenas nas etapas de diversificação alélica entre linhagens, sendo a variação intra linhagens, que explica as diferenças entre alelos relativamente semelhantes , principalmente neutra (linhagens como alvos de seleção).

Takahata e Satta (1998b) examinaram a diversidade nucleotídica sinônima entre $\left(\pi_{b}\right)$ e dentro $\left(\pi_{w}\right)$ de linhagens de $H L A$ e constataram que ambas são maiores para os éxons que abrigam os códons ARS do que para outros éxons e que o valor de $\pi_{w}$ é menor que $\pi_{b}$ para todos os éxons de todos os locos $H L A$ analisados. Uma constatação importante, contudo, foi a de que mesmo $\pi_{w}$ sendo menor do que $\pi_{b}, \pi_{w}$ é maior do que em locos não-HLA. Eles consideraram tanto a classificação "serológica" das linhagens quanto a classificação baseada em homologia de sequências. 


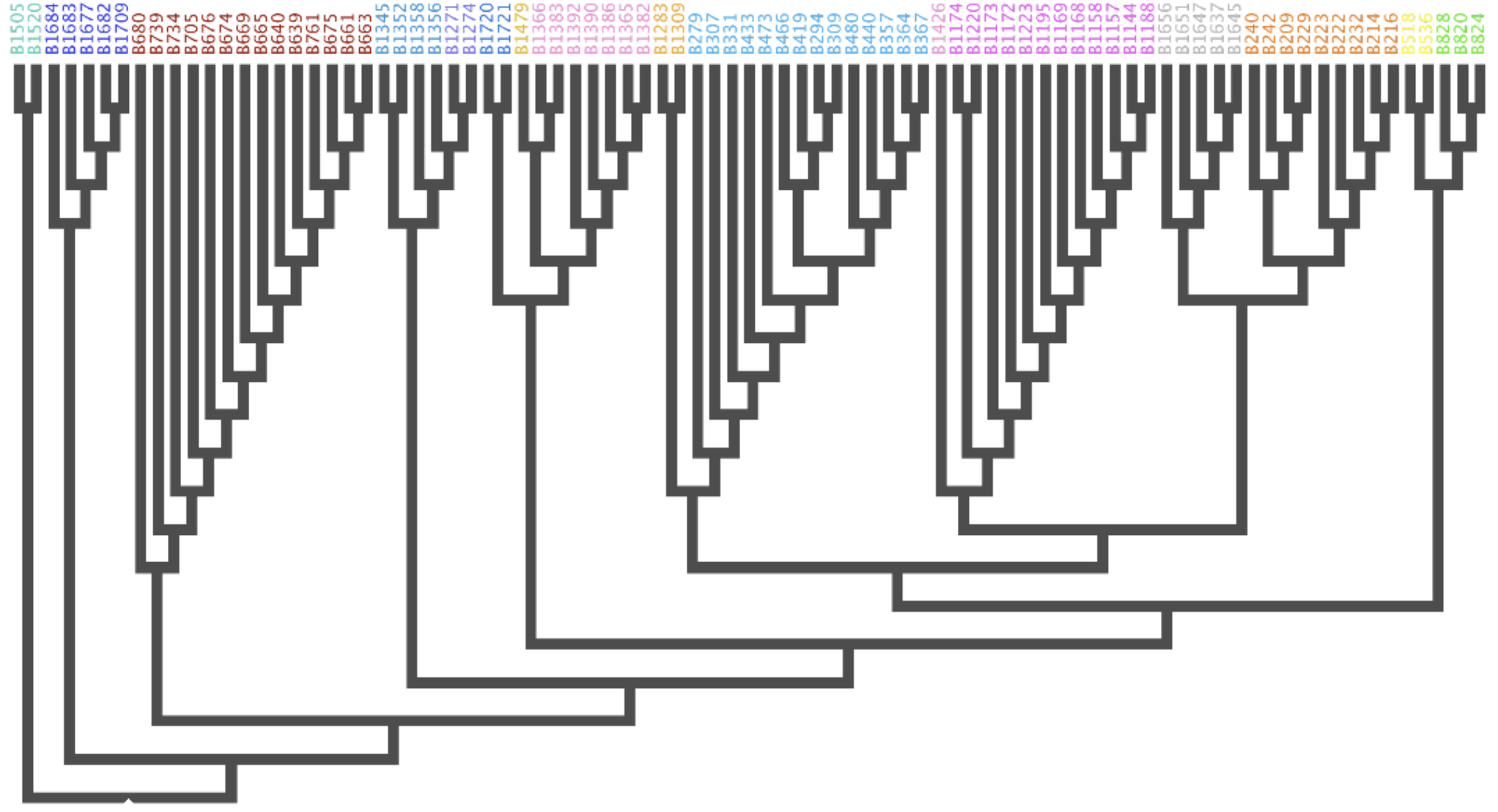

Figura 7. Árvore filogenética parcial de $\boldsymbol{H L A} \boldsymbol{A} \boldsymbol{B}$. Alelos de uma mesma linhagem são representados pela mesma cor. Os nomes dos alelos aqui são mostrados de forma numérica sequencial, e não correspondem aos nomes verdadeiros dos mesmos. 
Usando um teste de permutação eles verificaram que as diversidades nucleotídicas entre linhagens (nesse caso, a classificação de linhagem que estava sendo testada era a serológica) para os locos $H L A$ $A$ e $-C$ são consideravelmente maiores do que as esperadas caso as linhagens fossem aleatórias no que diz respeito às sequências. A designação de linhagens para os alelos $H L A-B$, por outro lado, não foi significativamente melhor que as designações aleatórias, uma possível consequência de eventos de recombinação intragênica serem comuns nesse loco Takahata e Satta (1998b).

Foi proposto, portanto, que as linhagens são agrupamentos historicamente significativos (para $H L A-A$ e $-C)$ e que contêm alelos que estão evoluindo sob seleção balanceadora.

Em uma análise populacional dos genes de classe I de aborígenes australianos, Gao et al. (1997) mostraram que apenas 4 alelos são comuns, e cada um desses alelos pertence a uma linhagem diferente. Isso levou Jakobsen et al. (1998) a sugerirem que a seleção favorece a permanência de alelos mais divergentes em populações pouco diversas, de forma a aumentar o repertório de ligação a antígenos. Dentro desse cenário, espera-se que a seleção dentro de linhagens seja menos intensa do que entre linhagens.

Adicionalmente, Richman et al. (2001) mostraram que para diversos genes do MHC não-humanos e locos classe II do $H L A$, os ramos terminais das genealogias alélicas eram mais longos do que o que se esperaria sob um modelo em que todos os genótipos heterozigotos são igualmente aptos (sobredominância simétrica). Eles argumentam que um modelo em que a aptidão do heterozigoto é proporcional à divergência de sequência entre os alelos (sobredominância assimétrica ou modelo da vantagem do alelo divergente) oferece uma melhor explicação para os dados. Intuitivamente, esperar-se-ia que um modelo que favorece heterozigotos com alelos divergentes geraria valores de $d_{N} / d_{S}$ mais altos para comparações entre alelos de linhagens distintas do que para alelos de uma mesma linhagem.

Dessa forma, Richman et al. (2001) sugerem que a diferenciação alélica dentro de linhagens (alelos filogeneticamente próximos) pode apresentar menos evidência de seleção do que comparações entre alelos de linhagens diferentes, assumindo-se que a seleção balanceadora em $H L A$ atuou, em grande parte, entre as linhagens.

A predição de Richman et al. (2001), portanto, é de que dentro de um modelo de sobredominância assimétrica espera-se um valor de $\omega$ maior entre as linhagens do que dentro das linhagens. Os resultado de Takhata e Satta (1998a) indicam, contrastantemente, que possivelmente a seleção foi marcante tanto entre as linhagens quanto dentro delas, levando-se em conta o padrão que observaram: a diversidade nucleotídica. Embora tenhamos discutido previamente que a seleção balanceadora aumenta a diversidade genética dos locos sob seleção, uma questão permanece em 
aberto: quantificar a intensidade de seleção dentro e entre linhagens, com uma ferramente capaz de fazê-lo de forma não ambíguia. Nesse sentido, a fim de testar hipóteses sobre seleção dentro e entre linhagens, a razão $d_{N} / d_{S}$ seria uma ferramenta muito mais adequada, pelas vantagens destacadas na subseção 1.4 na página 11. Nosso projeto focou em abordar justamente essa questão: quais foram os alvos principais da seleção balanceadora sobre os genes $H L A$ de classe I? 


\section{Objetivos}

Uma definição de alvo de seleção é : "O nível de organização biológica que exibe o fenótipo sob seleção" (Templeton, 2006). Em nosso trabalho, buscamos lidar com a definição do alvo de seleção na evolução dos genes $H L A$. Ainda não existe consenso acerca da importância relativa da seleção sobre linhagens e sobre alelos individuais na diversificação dos alelos do $H L A$, e essa foi a pergunta que decidimos investigar.

Nossa pergunta principal foi: os regimes de seleção que historicamente operaram sobre os genes $H L A$ o fizeram principalmente sobre as linhagens alélicas ou sobre os alelos individuais? Em outras palavras, qual foi o principal alvo da seleção balanceadora na evolução dos genes $H L A$ : linhagens ou alelos?

Nossa hipótese nula foi a de que as linhagens foram os alvos da seleção e a hipótese alternativa foi a de que os alelos individuais foram alvos da seleção ao longo da história evolutiva dos genes HLA. Especificamente, buscamos testar duas hipóteses relacionadas: (1) a de que alelos remotamente divergidos têm maior evidência de seleção balanceadora do que alelos com menor divergência (valendo-nos da premissa de que alelos de linhagens distintas são filogeneticamente mais distantes do que alelos de uma mesma linhagem, conforme esclarecemos na subseção 2.3) e; (2) a de que a seleção sobre os genes $H L A$ atuou mais intensamente entre as linhagens do que na diversificação dentro de cada linhagem.

As expectativas resultantes de nossa hipótese foram: (a) que haveria correlação positiva entre tempo de divergência dos alelos e a estatística de interesse, $d_{N} / d_{S}$; (b) que a razão $d_{N} / d_{S}$ seria significativamente mais alta para ramos entre-linhagens do que para ramos intra-linhagens e; (3) que a razão $d_{N} / d_{S}$ seria significativamente mais alta para ramos internos do que para ramos terminais.

Adicionalmente, buscamos avaliar o efeito de recombinação sobre inferências de sítios sob seleção e testes de hipóteses baseados em análises filogenéticas. Por fim, buscamos fazer uma validação do método de inferência de $d_{N} / d_{S}$ usando como estudo de caso os códons ARS e sua relação com a capacidade de inferência. Especificamente, testamos se o uso de uma classificação mais abrangente melhoraria nossa capacidade de responder às questões que colocamos anteriormente. 


\section{Parte II}

\section{Dados e Métodos}

\section{Abordagem par-a-par}

A primeira abordagem de análises consistiu em comparar todos os alelos entre si, para estimar a distribuição geral de $d_{N} / d_{S}$. Posteriormente, compararemos esses resultados com aqueles obtidos usando uma abordagem que usa informação filogenética sobre o parentesco entre alelos

\subsection{Obtenção de sequências}

Foi feita uma busca no banco de dados de HLA/IMGT (http://www.ebi.ac.uk/imgt/) por todos os alelos de $H L A$ de classe I. O sítio forneceu a atualização mais recente dos alinhamentos dos alelos ${ }^{23}$. Tais dados foram utilizados nas análises par-a-par subsequentes.

Utilizamos os alinhamentos de região codificadora dos alelos de $H L A$ de classe I clássicos ( $H L A$ $A,-B$ e $-C)$. Os alinhamentos foram editados através de um script caseiro em linguagem Perl, de forma a remover todos os alelos nulos (terminados em "N"), alelos que resultam em moléculas sub-expressas, expressas somente sob forma secretada ou, ainda, com mutações que tornam a sua expressão questionável (alelos cujos nomes são terminados em "L", "S" e "Q", respectivamente). No programa Se-Al (Rambaut, 1996) os alinhamentos foram visualizados e editados para a remoção de inserções e deleções presentes em alguns alelos, sem alterar o quadro de leitura. O mesmo programa possibilitou que os alinhamentos fossem exportados em formato compatível com o programa PAML (Yang, 2007), que foi utilizado para estimar $d_{N}, d_{S}$ e outros parâmetros de interesse (ver subseção 4.3 na página 29).

Foram selecionados apenas os alelos com sequências codificadoras completas para os éxons 2, 3 e 4. Os éxons 2 e 3 correspondem aos domínios $\alpha_{1}$ e $\alpha_{2}$, apresentados na figura 4 na página 16 . Todos os códons ARS dos genes de classe I estão situados nesses dois éxons. A incorporação do éxon 4 à base de dados foi feita a fim de que nossas estimativas de $d_{S(n \tilde{a} o-A R S)}$ como medida de divergência incorporassem posições fora da região apresentadora de antígenos. Para as análises par-a-par, uma filtragem adicional foi feita: dentro de um grupo de alelos idênticos para os códons ARS (ver definição de "ARS" na página 16), apenas um foi mantido nas análises subsequentes. Essa abordagem foi adotada pois, se as sequências não tivessem nenhuma substituição nos códons

\footnotetext{
${ }^{23}$ Release 3.1.0, Julho de 2010.
} 
ARS, a razão $\omega_{A R S}$ não poderia ser calculada. Na abordagem par-a-par, a comparação repetida de alelos sem nenhuma substituição sinônima leva à introdução de um viés no sentido de aumentar o valor médio de $d_{N} / d_{S(A R S)}{ }^{24}$, devido à inclusão de múltiplos pares de alelos com divergência muito baixa. Por outro lado, a razão é também considerada indefinida quando não há substituições não-sinônimas.Nosso filtro foi feito no sentido de, a priori, reduzir esse viés. ${ }^{25}$

Uma vez que apenas aqueles alelos que atenderam aos pré-requisitos acima dispostos foram utilizados, a base de dados utilizada nas análises par-a-par foi bastante reduzida em relação ao número total de alelos disponíveis no diretório do HLA/IMGT. A tabela 1 resume os dados de sequência referentes às análises baseadas em métodos par-a-par que serão descritas nas páginas 29 a 34. Apesar de a base de dados resultante ser reduzida em relação ao número de alelos existentes, ela atende aos propósitos do projeto, uma vez que o conjunto de alelos é suficientemente amplo para abranger desde pares de baixa até alta divergência.

Tabela 1. Dados de sequência para as análises par-a-par

\begin{tabular}{lcclr}
\hline Loco & Alelos Disponíveis & Alelos Usados & \multicolumn{2}{c}{ Códons Usados } \\
\hline$H L A-A$ & 1193 & 192 & Não-ARS & ARS \\
$H L A-B$ & 1799 & 375 & 227 & 48 \\
$H L A-C$ & 829 & 91 & 227 & 48 \\
$*$ * $A$ & & & & 48 \\
\hline
\end{tabular}

*Release 3.1.0, Julho de 2010

A descrição da classificação de códons ARS utilizada encontra-se na subseção 4.2.

\subsection{Definição de códons ARS, estimativas de divergência e determinação de linhagens}

Os códons ARS foram definidos de acordo com os peptide binding environments (PBEs) propostos por Chelvanayagam (1996) para os locos clássicos de classe I, totalizando 48 códons ARS ${ }^{26}$ (tabela 1). Os códons não-ARS foram definidos como o conjunto dos códons não-ARS dos éxons 2 e 3 (onde estão situados os códons ARS) e todos os códons do éxon 4 . O éxon 1 corresponde à sequência líder e, por isso, não foi utilizado nas estimativas que serão descritas na subseção 4.3.

A fim de definir o grau de divergência entre todos os possíveis pares de alelos, três alternativas foram propostas: (1) determinação de linhagens alélicas: o grau de parentesco entre dois alelos pode

\footnotetext{
${ }^{24}$ Como trata-se de uma razão, o programa, nessas situações, atribui o valor 99.0000 a uma razão que não pode ser calculada pois o denominador $\left(d_{S}\right)$ é zero.

${ }^{25} \mathrm{Na}$ subseção 4.5 na página 32 discutiremos outras medidas que tomamos para lidar com valores altos de $\omega$.

${ }^{26} \mathrm{~A}$ numeração dos sítios de classe I começa no éxon 2: a posição 1 corresponde ao primeiro códon do éxon 2 e assim por diante.
} 
ser considerado um indício de seu grau de divergência (alelos de linhagens distintas divergiram há mais tempo do que pares de alelos de uma mesma linhagem); (2) divisão dos pares em grupos de acordo com uma estimativa neutra de tempo de divergência e; (3) definição na topologia da árvore alélica quais pares de alelos divergiram recente ou remotamente, de acordo com algum critério previamente definido ou um limiar para o tamanho do ramo.

Nas análises par-a-par foram exploradas apenas as abordagens 1 e 2 (ou seja, aquelas independentes de uma árvore filogenética). Dentro da primeira abordagem, pares de alelos pertencentes a uma mesma linhagem foram classificados como "I" (intra) e pares de linhagens diferentes foram classificados como "E" (entre), e as estatísticas de interesse foram calculadas para cada subconjunto de pares, a fim de detectar eventuais diferenças. Os grupos de alelos pertencentes às mesmas linhagens ou a linhagens diferentes foram definidos com base no nome do alelo, uma vez que na nomenclatura adotada pelo HLA/IMGT, os dois primeiros algarismos do nome do alelo indicam a linhagem à qual ele pertence ${ }^{27}$.

Já na abordagem $2, d_{S(n \tilde{a} o-A R S)}$ foi utilizado como estimativa do tempo de divergência dos alelos, assumindo-se a premissa de que mudanças sinônimas, em geral, evoluem de modo neutro. Em função da estimativa de $d_{S(n \tilde{a} o-A R S)}$, os alelos foram atribuídos a quantis de divergência. Nesse caso, utlizamos quatro níveis de divergência: (1) $d_{S(n \tilde{a} o-A R S)} \leq$ ao valor do primeiro quartil; $(2) d_{S(n \tilde{a} o-A R S)}$

\subsection{Estimação de $d_{N}, d_{S}$ e $d_{N} / d_{S}$}

O programa CODEML do pacote PAML (Yang, 2007) foi utilizado para realizar as estimativas de $d_{N}, d_{S}$ e $\omega$ (entre outros parâmetros). As análises foram inicialmente feitas de forma par-a-par, sem o fornecimento de uma topologia de árvore filogenética (a opção par-a-par é controlada pelo parâmetro runmode=-2 do arquivo de controle do CODEML). Duas bases de dados foram analisadas separadamente para cada loco: (a) códons ARS, definidos de acordo com a definição da subseção 4.2 e (b) códons não-ARS (controle e base de dados a partir da qual foram feitas as estimativas de divergência). Para cada base de dados, foram executadas duas corridas no CODEML: uma foi feita fixando o parâmetro $\omega=1$ para todos os códons ( controlado pelos parâmetros fix_omega=1 e omega=1) e, na outra, $\omega$ foi estimado, para cada par, como uma média de todos os códons (fix_omega $=0$ e omega $=0)$.

Existem duas categorias de métodos para estimação de taxas de substituição: os métodos apro-

\footnotetext{
${ }^{27}$ Até abril de 2010, a nomenclatura dos alelos possibilitava apenas dois dígitos em cada campo. Portanto, nos casos em que as linhagens excediam o limite de 99 alelos requerido por esse nomenclatura, o restante dos alelos de uma linhagem passava a ocupar uma outra linhagem, por questões de numeração. A partir de abril de 2010 a numeração dos alelos deixou de ter o limite de 99 alelos por linhagem.
} 
ximados $(a d-h o c)$ e os métodos baseados em máxima verossimilhança. Os métodos aproximados envolvem etapas sucessivas: (1) contagem de sítios sinônimos e não-sinônimos; (2) contagem de diferenças sinônimas e não-sinônimas e; (3) correção para substituições múltiplas no mesmo sítio (códon). A maior parte desses métodos assume premissas não-realistas sobre o processo de substituição nucleotídica e envolvem tratamento $a d h o c^{28}$ dos dados que não podem ser justificados. É o caso, por exemplo, do método de Yang e Nielsen (2000). O método de Nei e Gojobori (1986), que também é ad hoc, assume taxas de transição e transversão iguais e uso uniforme de códons.

Entretanto, transições na terceira posição de um códon são mais frequentemente sinônimas do que as transversões. Ignorar $\kappa^{29}$ (ou seja, considerá-la igual a 1, sem estimá-la ou levar em conta o fato de que transições são mais comuns do que transversões) leva à subestimação do número de sítios sinônimos e superestimação do número de sítios não-sinônimos. Já o efeito do uso enviesado de códons, largamente ignorado pelos métodos ad-hoc, tem pronunciados efeitos sobre $d_{N}$ e $d_{S}$. Sítios sinônimos não são seletivamente equivalentes, e certos códons sinônimos (códons "ótimos") são usados mais frequentemente do que outros, possivelmente devido à seleção para eficiência e precisão da tradução (Powell e Moriyama, 1997). Os métodos de ML, que serão apresentados a seguir, também não resolvem essa questão. Entretanto, incorporam ao modelo as diferentes frequências dos códons, o que é assumido ser o resultado de um modelo de substituição mais complexo (Yang, 2006).

Os métodos de ML ("maximum likelihood" ou máxima verossimilhança) podem explicitamente incorporar aspectos da evolução do DNA. Esses modelos são baseados em cadeias de Markov e foram propostos por Goldman e Yang (1994) e por Muse e Gaut (1994). Nesses modelos, o códon é considerado a unidade de evolução e a cadeia de Markov é usada para descrever a substituição de um códon por outro. Os possíveis estados na matriz de substituição são os 61 códons do código genético universal ${ }^{30}$ (códons de parada não não permitidos em uma proteína funcional e, portanto, não são considerados na cadeia). As taxas são instantâneas (não há a possibilidade de múltiplas mudanças) e a teoria probabilística consegue abarcar todas as etapas anteriormente descritas para os métodos ad-hoc em um só passo, que inclui a estimação de todos os parâmetros de interesse, a correção para múltiplas substituições e a ponderação acerca da via de mudança entre códons (Yang, 2006).

O algoritmo de Goldman e Yang (referido daqui em diante como GY94) para estimação de taxas de substituição foi preferido em relação aos métodos aproximados pois trata-se de um modelo

\footnotetext{
${ }^{28}$ Essa expressão em latim genericamente refere-se a uma solução que foi encontrada para um problema específico, mas que não é generalizável e não é, por definição, adaptável para outros propósitos.

${ }^{29} \kappa($ (kappa) é a razão entre as taxas de transição e transversão.

${ }^{30} \mathrm{Ou} 60$, no código genético mitocondrial dos vertebrados.
} 
baseado em códons que considera mais atributos da sequência de DNA (por ex. $\kappa$ e variação na frequência de códons) (Yang, 2006). Sabe-se que as estimativas baseadas em GY94 são estatisticamente consistentes quando o modelo é correto (Stuart et al., 1999). Além disso, estudos com simulações mostram que estimativas de parâmetros feitas com base nesse método têm alta precisão e devem ser sempre preferidas, salvo quando o número de códons das sequências é muito pequeno; nesses casos, métodos aproximados podem ser preferidos (Yang e Nielsen, 2000). O modelo GY94 foi usado também nas análises filogenéticas ${ }^{31}$.

No modelo GY94, a matriz de substituição de um códon $i$ por um códon $j$ (ou seja, a probabilidade de mudança de um códon para outro) é dada por:

$$
q_{i j}=\left\{\begin{array}{cccccccc}
0, & \text { se } & i & e & j & \text { diferem } & \text { em } 2 \text { ou } 3 & \text { posiçõesdocódon } \\
\pi_{j}, & \text { se } & i & e & j & \text { diferem } & \text { poruma } & \text { transversãosinônima } \\
\kappa \pi_{j}, & \text { se } & i & e & j & \text { diferem } & \text { poruma } & \text { transiçãosinônima } \\
\omega \pi_{j}, & \text { se } & i & e & j & \text { diferem } & \text { poruma } & \text { transversãonão-sinônima } \\
\omega \kappa \pi_{j}, & \text { se } & i & e & j & \text { diferem } & \text { poruma } & \text { transiçãonão-sinônima }
\end{array}\right\}
$$

, onde $\kappa$ é a razão entre as taxas de transição e transversão, $\omega=d_{N} / d_{S}$ e $\pi_{j}$ é a frequência dos códons $j$, em equilíbrio. Usando-se o parâmetro $\pi$ para a frequência de um códon (calculada a partir das sequências analisadas), o viés no uso de códons é levado em conta na estimação das substituições.

Há diferentes modelos que podem ser assumidos para descrever a frequência dos códons: Pode-se assumir: (1) que todos possuem a mesma frequência (Fequal); (2) que as frequências dos códons dependem das frequências dos quatro nucleotídeos (F1x4, com 3 parâmetros livres); (3) que as frequências dos códons dependem das frequências de cada nucleotídeo em cada posição do códon (F3x4, com 9 parâmetros livres) ou; (4) que a frequência de cada códon é um parâmetro livre (F61) (Yang, 2006). Em todas as análises descritas daqui em diante, adotamos a opção F3x4 (Yang, 2003).

\subsection{Teste de razão da verossimilhança}

A análise de verossimilhança é um método estatístico que calcula a probabilidade dos dados observados sob um modelo pré-especificado, de forma a estimar parâmetros sob modelos que melhor expliquem os dados observados e determinem as forças relativas das hipóteses alternativas (Posada e Buckley, 2004).

\footnotetext{
${ }^{31}$ O GY94 original foi utlizado nas análises par-a-par. Nas filogenéticas, versões modificadas do ML aqui descrito, que permitem que $\omega$ varie entre códons e ao longo de diferentes linhagens, foram adotados, conforme será descrito mais adiante.
} 
O teste de razão da verossimilhança $(\mathrm{LRT})^{32}$ é um método poderoso para o teste de hipóteses que dizem respeito a parâmetros de modelos estimados por verossimilhança. Ele compara duas hipóteses (modelos) aninhadas ${ }^{33}$, formuladas a priori. Suponhamos que a hipótese nula, $H_{0}$, envolva $p_{0}$ parâmetros e que a hipótese alternativa, $H_{1}$, seja uma extensão de $H_{0}$, com $p_{1}$ parâmetros, sendo $p_{1}>p_{0}$. Suponhamos, ainda, que os valores de ln da máxima verossimilhança sob os dois modelos sejam $l_{0}=\log \left\{L\left(\theta_{0}\right)\right\}=l\left(\theta_{0}\right)$ e $l_{1}=\log \left\{L\left(\theta_{1}\right)\right\}=l\left(\theta_{1}\right)$, onde $\theta_{0}$ e $\theta_{1}$ são as estimativas de parâmetros com máxima verossimilhança sob os dois modelos, respectivamente. Então, sob certas condições de regularidade, a estatística do teste de razão da verossimilhança é dada por:

$$
2 \Delta l=2 \log \left(L_{1} / L_{0}\right)=2\left(l_{1}-l_{0}\right)
$$

e segue uma distribuição qui-quadrado $\left(\chi_{p_{1}-p_{0}}^{2}\right)$ assintótica se $H_{0}$ for verdadeira. Em outras palavras, se o modelo nulo for verdadeiro, o dobro da diferença entre o log da verossimilhança do modelo nulo e do alternativo segue uma distribuição aproximadamente igual à $\chi^{2}$ (chi-quadrado) com graus de liberdade iguais à diferença entre os números de parâmetros dos dois modelos. A aproximação se aplica para amostras grandes (Yang, 2006). Existem outras formas de comparar modelos, como o AIC (Akaike information criterion), que muitas vezes é utilizado como alternativa ao LRT nos casos em que os modelos não são aninhados (Posada e Buckley, 2004). Como nossas análises envolveram a comparação de modelos aninhados, optamos pelo LRT.

\subsection{Análises estatísticas}

As tabelas com os resultados obtidos no PAML foram analisadas no pacote estatístico R (2009). Percebemos que certos valores de $\omega$ são altos devido a um viés relacionado a baixos valores do denominador, $d_{S}$. Sendo assim, um filtro inicial foi feito, transformando todos os valores de $\omega=$ 99.000 em dados faltantes (NAs). Quando $d_{S}$ é muito baixo (por exemplo, para alelos de uma mesma linhagem), a razão $\omega$ é frequentemente muito alta, o que não necessariamente é indicativo

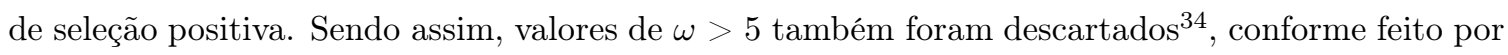
Wolf et al. (2009).

A fim de demonstrar que a exclusão dos pares com $\omega>5$, apesar de arbitrária, não compromete

\footnotetext{
${ }^{32}$ Likelihood ratio test.

${ }^{33}$ Em outras palavras, um modelo é um caso especial do outro.

${ }^{34}$ Valores de $\omega=99$ ocorrem quando o denominador, $d_{S}$ é muito próximo de zero, e não devem ser considerados. Para um gene, valores muito altos de $d_{N} / d_{S}$ podem indicar que o valor preciso é difícil de ser estimado, como consequência de valores baixos de $d_{S}$. Examinamos os pares em que $\omega>$ alguns valores e percebemos que nesses casos o valor de $d_{S}$ era muito baixo. Para testar a hipótese de que, $\omega>1$, a melhor alternativa é usar o LRT. Quando se calcula a média de valores de $\omega$ em uma abordagem par-a-par, o limiar de valores de $\omega$ aceitáveis é arbitrário (Ziheng Yang, comunicação pessoal). Aqui, experimentamos limiares de $\omega=3,5,10,20,50$ e 99 (o maior valor possível no CODEML) e os resultados permaneceram essencialmente os mesmos (ver discussão no texto).
} 
Tabela 2. Efeito da remoção de pares com $\omega$ alto

\begin{tabular}{cccccccc}
\hline Valores & sem filtro & $\omega<99$ & $\omega<50$ & $\omega<=20$ & $\omega<=10$ & $\omega<=5$ & $\omega<=3$ \\
\hline Mediana & 1.43 & 1.17 & 1.17 & 1.17 & 1.16 & 1.16 & 1.13 \\
Média & 30.68 & 1.48 & 1.41 & 1.38 & 1.36 & 1.31 & 1.23 \\
Terceiro quartil & 3.08 & 1.74 & 1.74 & 1.73 & 1.73 & 1.71 & 1.63
\end{tabular}

Os dado referem-se à base de dados ARS de $H L A-A . \omega<99$ significa que apenas pares que atendem a esse critério foram considerados.

nossas inferências, comparamos as estimativas de $\omega_{A R S}$ e $\omega_{(n \tilde{a} o-A R S)}$ com a aplicação de diferentes "filtros" (ver a tabela 2). Nota-se que a única grande mudança ocorre entre a situação "sem filtro" para a seguinte (remoção de pares com $\omega>=99$ ). E mesmo nesse caso, apenas a média sofre uma grande redução, de 30.68 para 1.48, ao passo que o valor da mediana e do terceiro quartil não sofrem tamanha redução. Conforme discutimos aqui, os valores "99" não devem ser incorporados como "forte evidência de seleção". Pelo contrário: eles servem para mostrar a sensibilidade do método, ilustrando que em casos de poucas substituições entre os pares, a razão $d_{N} / d_{S}$ não é informativa. Comparando todos os outros filtros, percebe-se que a média sofre pouca mudança (continuando > 1), e, mais importante, os valores da mediana e do terceiro quartil permanecem razoavelmente estáveis. Como percebemos uma mudança maior entre os resultados gerados com os filtros $\omega<5$ e $\omega<3$, optamos pelo primeiro. A tabela 2 refere-se a $H L A-A$, mas a mesma tendência foi verificada para os locos $H L A-B$ e $H L A-C$ (dados não-mostrados).

Primeiramente os pares foram divididos em função de quartis de divergência em termos de $d_{S(n \tilde{a} o-A R S)}$ (a medida de divergência aproximadamente neutra que optamos por utilizar), e as distribuições de $\omega_{A R S}$ foram comparadas entre essas diferentes categorias.

A fim de testar a existência de possíveis correlações entre o tempo de divergência $\left(d_{S(n \tilde{a} o-A R S)}\right)$ e $\omega_{(A R S)}$, usamos um script caseiro em linguagem $\mathrm{R}$ capaz de executar um teste de Mantel (ver algoritmo 3 na página 86, nos anexos). Diversos pacotes no $\mathrm{R}$ possibilitam ao usuário executar testes de Mantel. Entretanto, em geral eles apresentam um dos seguintes problemas: (1) requerem objetos da classe "dist" para rodar; ou (2) não lidam com dados faltantes (NAs). Além disso, a intenção aqui foi a de fazer testes de Mantel entre duas matrizes de saída do programa PAML. Por esses motivos optamos por fazer nosso próprio programa.

Os pares de alelos foram divididos em "E" (entre-linhagens, quando os membros do par eram de linhagens distintas) e "I" (intra-linhagens, quando os membros de um par eram de uma mesma linhagem). Como as variáveis de interesse não seguem uma distribuição normal, um teste de correlação convencional (como o de Pearson) não seria adequado. Portanto, fizemos 1000 permutações das matrizes de valores $\omega_{A R S}$ e $d_{S(n \tilde{a} o-A R S)}$ e calculamos a correlação entre elas em cada caso. 
Desta forma, geramos uma distribuição nula e verificamos onde nosso valor empírico de correlação se encaixava nessa distribuição. De forma semelhante, calculamos a estatística $t$ de Student entre os valores de $\omega$ "I" e "E" e comparamos a uma distribuição nula de valores de gerada por pelo menos 1000 randomizações dos dados) para testar as diferenças entre as médias de $d_{N} / d_{S(A R S)}$ dos pares E e I (ver algoritmo 2 na página 85 , nos anexos).

Seria interessante que o objeto de entrada dos dois programas pudesse ser uma matriz simétrica (formato ideal para realizar as permutações previstas nos dois programas) e que houvesse alternativas para lidar com dados faltantes. Os valores de saída do PAML são em forma de vetor. Mas como, nesse caso, são provenientes de análises par-a-par, é relativamente simples transformá-los em matrizes simétricas. Como ambos os algoritmos descritos acima requerem como objeto de entrada matrizes simétricas, desenvolvemos um script caseiro em linguagem R que transforma um vetor com resultados de análises par-a-par do PAML em uma matriz simétrica (ver algoritmo 1 na página 84, nos anexos).

Por fim, fizemos um LRT entre o modelo de uma razão $\omega$ estimada versus o modelo com $\omega=1$, (valor fixado, controlado pelos parâmetros fix_omega=1 e omega=1) a fim de verificar a significância dos valores de $\omega_{A R S}$ encontrados.

\subsection{Simulação}

Fizemos uma simulação a fim de averiguar os padrões esperados para as distribuições de $\omega_{A R S} \mathrm{em}$ função de $d_{S(n \tilde{a} o-A R S)}$.

A intenção foi a de gerar uma distribuição nula de valores de correlação entre essas duas variáveis, sob um regime de $\omega_{A R S}$ constante ao longo do tempo de divergência alélica (usando $d_{S(n \tilde{a} o-A R S)}$ como medida aproximada para o tempo de divergência alélico).

A simulação foi feita para o loco $H L A$ - $A$ e consistiu em simular 100 bases de dados ARS e 100 bases de dados não-ARS no programa EVOLVER do pacote PAML ${ }^{35}$. Os parâmetros utilizados $(\omega$, $\kappa$, frequências de códons, número de códons das sequências e número de sequências) foram aqueles obtidos pelas análises par-a-par descritas anteriormente. Posteriormente, estimamos as estatísticas de interesse para essas 200 bases de dados através do programa CODEML (parâmetro ndata=100, runmode $=-2$ ), usando os mesmos parâmetros obtidos nas análises par-a-par descritas anteriormente na subseção 4.3 .

\footnotetext{
${ }^{35}$ Ambas as bases de dados foram condicionadas à topologia filogenética fornecida pela base de dados não-ARS. A matriz de distância foi gerada pelo programa DNADIST e a topologia filogenética foi gerada pelo programa NEIGHBOR, ambos do pacote PHYLIP, de forma análoga àquela descrita na seção 5 na próxima página.
} 


\section{Abordagem filogenética}

Nas análises filogenéticas, a disponibilidade das topologias possibilitou a utilização dos modelos de seleção sobre conjuntos de ramos específicos (branch models, disponíveis no PAML) e testar a hipótese de que a seleção sobre $H L A$ ocorreu majoritariamente entre linhagens. Foi possível, ainda, utilizar os modelos de seleção sobre sítios específicos (site models) a fim de verificar quais códons possuem evidência de seleção positiva.

As análises de seleção sobre códons e sobre linhagens assumem uma única topologia filogenética e não levam em conta a recombinação (Furlong e Yang, 2008). Entretanto, já foi sugerido que tanto a recombinação intra quanto a intergênica desempenham um importante papel na evolução da família gênica HLA (She et al., 1991). Como é bastante aceito que a topologia de uma árvore filogenética pode alterar bastante os resultados de testes de seleção e que a recombinação altera essas topologias (Schierup e Hein, 2000, 2000a), todas as análises filogenéticas que serão descritas a seguir foram feitas com uma base de dados completa (não-filtrada) e uma base de dados sem recombinantes, para fins de comparação.

Apesar de esperarmos alterações importantes nos resultados, em termos de detecção de sítios sob seleção através dos modelos de seleção sobre sítios, principalmente (Anisimova et al., 2003), essa abordagem não nos desviou da proposta de trabalho: entender o alvo da seleção e as diferenças intra e inter linhagens. Ressaltamos, entretanto, que os recombinantes são de grande interesse devido à sua reconhecida importância na evolução dos genes $H L A$ (She et al., 1991). Por essa razão, nossa intenção não foi a de ignorar a existência dos recombinantes em nossas inferências, tampouco excluí-los das análises, simplesmente. Alternativamente, optamos por comparar nossos resultados para ambas as bases de dados. A descrição de como foi feita a exclusão de alelos recombinantes das bases de dados está na subseção 5.2 na página seguinte.

As matrizes de distância foram obtidas a partir dos alinhamentos através do programa DNADIST do pacote PHYLIP (Felsenstein, 2005). Nesse programa usamos o modelo de substituição de Felsenstein (1984). As árvores filogenéticas de Neighbor-joining (NJ) (Saitou e Nei, 1987) baseadas nessas matrizes foram obtidas através do programa NEIGHBOR, também disponível no pacote PHYLIP. Foram inferidas árvores para as bases de dados ARS e não-ARS. Em todas as análises filogenéticas utilizamos a topologia gerada para a base de dados não-ARS ${ }^{36}$. A justificativa é que a base de dados não-ARS fornece a melhor estimativa possível do background histórico, que carateriza

\footnotetext{
${ }^{36}$ Em todas as análises filogenéticas usamos apenas a topologia das árvores geradas por NJ, mas não usamos os comprimentos de ramos, pois eles se referem a número de subsituições por sítio (um nucleotídeo na sequência), ao passo que nos modelos implementados no CODEML, as taxas de substituição e os comprimentos de ramos estimados referem-se a substituições por códon.
} 
a evolução das sequências.

Primeiramente foram usados os modelos de seleção sobre sítios (site models, disponíveis no programa CODEML ${ }^{37}$ ), que permitem que o regime de seleção varie entre os códons de uma sequência. Esses modelos permitem inferir quais posições específicas estão sob seleção, e permitem, ainda, nossa validação das classificações comumente usadas de códons ARS (ver subseção 7.1 na página 50, nos resultados). Buscamos inferir quais códons têm evidências de seleção, a fim de, possivelmente, expandir a classificação de códons ARS de forma e englobar mais sítios sob seleção e, assim, aumentar o poder estatístico nas análises que realizamos.

Em um segundo momento, após termos avaliado a a classificação de códons ARS que pretendíamos utilizar, implementamos os testes de seleção sobre linhagens, também disponíveis no CODEML (ver subseção 5.4 na página 39, nos métodos).

\subsection{Obtenção de sequências}

As sequências codificadoras foram obtidas a partir da mesma versão do HLA/IMGT, descrito na subseção 4.1 na página 27. A etapa de edição dos alinhamentos foi feita conforme descrito para a abordagem par-a-par na subseção 4.1 na página 27. Entretanto, nenhum filtro foi aplicado aos dados, diferentemente do que descrevemos para as análises par-a-par.

\subsection{Detecção e remoção de sequências recombinantes}

Fizemos as duas etapas de análises filogenéticas (seleção sobre códons e seleção sobre linhagens) com duas bases de dados distintas: no caso dos modelos de seleção sobre códons, a bases de dados englobou todos os alelos com sequências codificadoras completas (éxons 2-6, conforme detalharemos na página 37). No caso dos modelos de seleção sobre conjuntos de ramos específicos, a base de dados foi basicamente a mesma, conforme detalharemos na página 39. Para cada uma dessas bases de dados criamos uma nova, em que os alelos recombinantes foram removidos. Essas bases de dados serão chamadas de SR ("sem recombinantes") e as com recombinates serão chamadas de "CR", daqui em diante.

Utilizamos o alinhamento inicial contendo todos os alelos com sequências codificadoras completas, exceto éxons 1 e 7 para determinar os alelos recombinantes para cada loco através do programa RDP3 (Martin et al., 2010). O RDP3 inclui vários programas destinados a detectar recombinantes e pontos de recombinação, através de diferentes abordagens. A fim de otimizar a capacidade de

\footnotetext{
${ }^{37}$ Note que aqui, "sítio" refere-se a um códon, e não a um nucleotídeo. Por isso, daqui em diante, eles serão chamados de "modelos de seleção sobre códons".
} 
detecção de recombinantes do programa, o qual inclui muitos parâmetros, foi construída uma base de dados "teste" contendo um caso conhecido (em $H L A-B)^{38}$ de um recombinante e suas sequências "doadora" e "receptora" 39 . Os parâmetros foram alterados até que o programa fosse capaz de detectar esse caso de recombinação, sem ambiguidade.

Nas opções do RDP3, foram escolhidos os programas RDP, Chimaera, Maxchi, GENECONV, BootScan e SiScan para a busca, e foi adotado o critério de que apenas eventos de recombinação detectados por mais do que dois desses programas fossem mostrados. Nas opções do programa RDP, o tamanho da janela foi reduzido para 15 e no BootScan e no SiScan para 100. O número de sítios variáveis por janela foi reduzido para 35 e 30 para o Maxchi e o Chimaera, respectivamente. Todos os outros parâmetros foram os parâmetros-padrão do programa. Os casos em que apenas uma evidência superficial de recombinação foi detectada ("trace evidence") foram ignorados, pois referem-se a casos em que o $p$-valor foi maior do que o estabelecido (nesse caso, o limiar escolhido foi de $p<0.05)$.

Um estudo de genética de populações de larga escala sugere que novos alelos de HLA-DRB1 são continuamente gerados por conversão gênica ${ }^{40}$ (Von Salomé et al., 2007). Embora o fenômeno pareça ser mais comum em locos de classe II (Che et al., 2007), fizemos uma inspeção visual para detectar casos de microconversões, bastante comuns em HLA (Takahata e Satta, 1998b), e que pudessem não ter sido detectados pelo programa RDP3. Usando a definição de linhagens alélicas previamente apresentada (subseção 2.3 na página 22), definimos as sequências pertencentes a uma mesma linhagem. Consideramos recombinantes as sequências contendo trechos diferentes do padrão de sua respectiva linhagem em pelo menos três sítios polimórficos, e estando este trecho em alguma das outras linhagens.

Tanto no caso dos modelos de seleção sobre códons quanto dos modelos de seleção sobre linhagens, utilizamos as bases de dados CR e SR, a fim de verificar o quanto os recombinantes podem enviesar resultados de análises filogenéticas.

\subsection{Determinação de sítios sob seleção positiva}

Nessa etapa, apenas os alelos com sequências codificadoras completas para alelos de $H L A-A, H L A-B$ e $H L A$ - $C$ foram mantidos, sendo que o primeiro e o último éxons (1 e 8 em $H L A-A$ e $H L A-C ; 1$ e 7 em $H L A-B$ ) foram excluídos. A tabela 3 na página seguinte mostra os dados de sequência usados

\footnotetext{
${ }^{38}$ Nesse exemplo a que nos referimos o trecho de recombinação foi identificado visualmente, através do programa MEGA (Kumar et al., 2008), que destaca os sítios polimórficos de um alinhamento.

${ }^{39}$ A sequência doadora é a que "doa", por recombinação, um segmento de DNA para uma sequência receptora.

${ }^{40} \mathrm{Um}$ dos tipos de recombinação homóloga que envolve a transferência unidirecional de material genético de uma sequência "doadora" para uma sequência "receptora" altamente homóloga.
} 
nessa etapa, tanto para a base de dados CR como para a base de dados SR.

Na abordagem par-a-par, a definição de códons ARS utilizada foi aquela proposta por Chelvanayagam (1996). Na abordagem filogenética, a possibilidade de usar os modelos de seleção sobre códons motivou uma verificação de quais sítios da molécula $H L A$ estão, de fato, sob seleção e qual

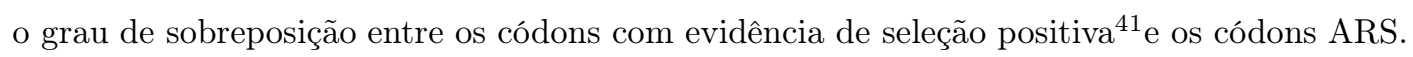

Buscamos especificamente comparar as classificações clássicas de códons ARS para $H L A$ de classe I, baseadas nas estruturas cristalográficas de complexos MHC-peptídeo, presentes na literatura (Bjorkman et al., 1987; Chelvanayagam, 1996) com estudos de verificação de seleção sobre os códons ARS (Yang e Swanson, 2002) utilizando os modelos de seleção sobre códons disponíveis no PAML.

Tabela 3. Dados de sequência para as análises de seleção sobre códons

\begin{tabular}{ccccc}
\hline Loco & Alelos Disponíveis* & Alelos Usados (CR) & Alelos Usados (SR) & Códons Usados \\
\hline$H L A-A$ & 1193 & 144 & 107 & 340 \\
$H L A-B$ & 1799 & 233 & 78 & 324 \\
$H L A-C$ & 829 & 133 & 109 & 341 \\
\hline
\end{tabular}

* Release 3.1.0 (Julho de 2010)

As diferenças no número de códons usados em cada loco são devidas a pequenas diferenças no tamanho e quantidade éxons nos diferentes locos

Usamos os modelos de seleção sobre sítios: M0 (uma razão) - que assume a existência de apenas uma razão $\omega$ para todos os códons (é o modelo mais simples e foi usado apenas para conferir se as estimativas de parâmetros dos modelos mais complexos eram consistentes); M1 (neutro), que assume a existência de duas categorias de sítios, sendo uma com $\omega_{0}<1$ (sítios evoluindo sob seleção purificadora), estimado a partir dos dados, e a outra com $\omega_{1}=1$ (sítios evoluindo de modo neutro); M2 (seleção), que acrescenta uma categoria de sítios ao M1, onde $\omega_{2}>1$; M7 (beta), um modelo nulo flexível, em que o valor de $\omega$ para um códon é um valor sorteado de uma distribuição $\beta^{42}$, com $0<\omega<1$ e $;$ M8, que acrescenta uma categoria ao M7, em que $\omega_{S}>1$, estimada a partir dos dados. Esses diferentes modelos são controlados pelo parâmetro "NSsites" do arquivo de controle do CODEML. É possível comparar os modelos M1 e M2, e M7 e M8, através de LRTs. Em ambas as comparações (M1 versus M2; M7 versus M8) é esperado que o uso de $\chi_{2}^{2}$ (distribuição qui-quadrado com 2 graus de liberdade) torne o teste conservador (Yang, 2006).

Uma vez determinado, através dos LRTs entre os modelos de sítios descritos acima, qual o

\footnotetext{
${ }^{41}$ Falamos aqui em seleção positiva, e não balanceadora, pois é como o PAML apresenta os resultados em que $\omega>1$ (significativamente). Conforme discutimos na seção 1.2 , a assinatura de $\omega>1$ é compatível tanto com seleção positiva quanto com seleção balanceadora.

${ }^{42}$ A distribuição beta restringe $\omega$ ao intervalo (0,1), mas pode assumir uma variedade de formas (tais como L, J, U e U invertido) de acordo com seus dois parâmetros, $p$ e $q$ (Yang, 2006; Yang et al., 2000). É, portanto, um modelo nulo flexível.
} 
modelo que melhor explica os dados, foram obtidos os sítios sob seleção positiva através do Bayes Empirical Bayes (BEB), fornecido pelo programa CODEML. Esses códons foram então comparados às definições de códons ARS pré-existentes. A topologia de árvore usada, em todos os casos, foi a da base de dados codificadora completa, descrita acima.

Todos os testes foram feitos para as bases de dados CR e SR, para fins de comparação. Os resultados desta etapa encontram-se na subseção 7.1 na página 50.

\subsection{Análises filogenéticas de modelos de seleção sobre linhagens especí- ficas}

Nessa etapa, o intuito foi o mesmo das análises par-a-par: (a) investigar qual foi o principal alvo da seleção ao longo da história evolutiva dos genes $H L A$ (alelos individuais ou linhagens alélicas) e; (b) verificar se os regimes seletivos foram constantes ao longo do tempo (comparar ramos internos e terminais). Os códons não-ARS dos éxons 2 e 3 e os éxons 4-7 (HLA-A e $H L A-C$ ) e os éxons 4-6 (HLA-B) constituíram a base de dados não-ARS, conforme definido na subseção 4.2 na página 28. A tabela 4 mostra os dados de sequência utilizados nessa etapa, tanto para as bases de dados CR como para as bases de dados SR.

Tabela 4. Dados de sequência para as análises de seleção sobre linhagens

\begin{tabular}{cccccr}
\hline Loco & Alelos Disponíveis* & Alelos Usados (CR) & Alelos Usados (SR) & \multicolumn{2}{c}{ Códons Usados } \\
\hline & & & & Não-ARS & ARS \\
$H L A-A$ & 1193 & 138 & 104 & 292 & 48 \\
$H L A-B$ & 1799 & 173 & 71 & 276 & 48 \\
$H L A-C$ & 829 & 125 & 110 & 293 & 48 \\
\hline
\end{tabular}

* Release 3.1.0 (Julho de 2010)

As topologias de árvore foram geradas pela base de dados não-ARS para as análises da base de dados ARS.

Nas análises filogenéticas, testamos duas hipóteses: (1) a de que a intensidade de seleção sobre $H L A$ difere entre ramos "E" e ramos "I"; (2) a de que a seleção que atuou sobre ramos terminais (ramos "T") difere daquela que atuou sobre ramos internos da filogenia (ramos "In").

Para cada loco foram estimadas as taxas $d_{N}$ e $d_{S}$ (para a base de dados ARS) com o programa CODEML, com um valor de $\omega$ único estimado para todas as linhagens (model=0) e com estimativas livres de $\omega$ para cada ramo (model=1). Em seguida, o programa foi rodado com model $=2$, onde $\omega$ pode assumir dois valores: um para ramos "E" e um para ramos "I", para o primeiro teste de hipóteses e; um para ramos "T" e um para ramos "In", para o segundo teste de hipóteses ${ }^{43}$. Para

\footnotetext{
${ }^{43}$ Esse modelo permite que o usuário classifique os ramos da árvore em duas ou mais categorias. Um valor de $\omega$ é
} 
análises com model=2, foi necessário colocar "etiquetas" em cada ramo da árvore filogenética (branch labels), determinando se o mesmo se enquadrava na categoria "I" ou "E"- para o primeiro teste de hipótese - ou "T" ou "In" - para o segundo teste de hipótese. A visualização dessas "etiquetas" foi feita no programa Mesquite (Maddison e Maddison, 2010) .

Os alelos que, através da análise de NJ, não se agruparam no clado de suas respectivas linhagens foram excluídos dessas análises, uma vez que o interesse estava em classificar os ramos como "I" ou "E"44. A tabela 4 na página anterior mostra o número se sequências restantes após essa seleção, e que foram utilizadas para ambos os testes de hipótese.

As verossimilhanças dos modelos 0 e 2 puderam ser então comparadas através de um LRT com um grau de liberdade a fim de testar a hipótese de que um modelo com duas categorias de ramos com valores estimados de $\omega$ (I e E; In e T) se ajusta melhor aos dados do que um modelo de um valor de $\omega$ estimado em conjunto para todas as linhagens. Além disso, o LRT entre o modelo 2 com $\omega=1$ (fixado) e modelo 2 com $\omega$ estimado a partir dos dados, permitiram avaliar se $\omega$ é significativamente $>1$. Os resultados dessas análises serão apresentados e discutidos na subseção 7.3 na página 64 .

Por fim, comparamos o modelo 2 com $\omega=1$ para ambas as categorias (I e E ou In e T) ao modelo 2 com $\omega$ estimado para essas categorias. A intenção foi a de avaliar a significância de eventuais valores de $\omega>1$ para essas categorias.

Todas as análises exploratórias dos dados e os testes de hipótese foram feitos com o pacote estatístico R e os resultados desta etapa encontram-se nas páginas 64 a 70.

\footnotetext{
então estimado para cada categoria.

${ }^{44}$ Adotamos esse medida pois era importante, para a hipótese que queríamos testar, que todos os ramos pudessem ser classificados como "I" ou "E". Mesmo na comparação In x T mantivemos a mesma base de dados "filtrada", a fim de podermos comparar os resultados obtidos nas duas abordagens.
} 


\section{Parte III}

\section{Resultados e Discussão}

\section{Análises par-a-par}

Utilizando a abordagem par-a-par, calculamos as estatísticas $d_{N}, d_{S}$ e $\omega$ no programa CODEML para cada par de alelos. A tabela 5 mostra um resumo geral do número médio de substituições encontradas entre pares de alelos $H L A$, para cada loco. Percebe-se que o número absoluto de substituições não-sinônimas $(N)$ e sinônimas $(S)$ na base de dados não-ARS é aproximadamente igual, nos três locos.

Isso é esperado, pois assumindo-se que apenas os códons ARS estão sob seleção positiva, a seleção purificadora nos códons não-ARS reduz o número de $N$ em relação ao esperado sob evolução neutra. Essa ação da seleção purificadora sobre os códons não-ARS fica mais clara ainda quando observamos que $\omega_{(n \tilde{a} o-A R S)}<1$, para os três locos (ver tabela 6 na página 43 ).

Já na base de dados ARS, o número de substituições não-sinônimas é cerca de 11 vezes maior (para $H L A-A$ ), do que o de substituições sinônimas (tabela 5). Isso é esperado uma vez que a tabela mostra o número absoluto de substituições e, de fato, existem mais sítios não-sinônimos do que sinônimos. Além disso, é sabido que a seleção positiva e a balanceadora atuaram sobre os códons ARS aumentando o número de substituições não-sinônimas.

A média de $\omega_{A R S}$ (de todos os pares para cada loco) é maior do que $\omega_{(n \tilde{a} o-A R S)}$, sendo que $\omega_{A R S}>1$ e $\omega_{(n \tilde{a} o-A R S)}<1$ para os três locos (ver a tabela 6$)$. Esses resultados reforçam observações anteriores feitas para $H L A$ (Hughes e Nei, 1988; Meyer, 2004). Além disso, $d_{N(A R S)}$ e $d_{S(A R S)}$ tendem a aumentar com a divergência dos alelos (ver figuras A.3, A.4 e A.5, nos anexos).

Tabela 5. Substituições sinônimas e não-sinônimas em locs de $H L A$ classe I

\begin{tabular}{|c|c|c|c|c|}
\hline Loco & \multicolumn{2}{|c|}{ Substituições (não-ARS) } & \multicolumn{2}{|c|}{ Substituições (ARS) } \\
\hline & $N$ & $S$ & $N$ & $S$ \\
\hline$H L A-A$ & 8.41 & 8.39 & 15.01 & 1.34 \\
\hline$H L A-B$ & 6.42 & 6.38 & 17.59 & 1.42 \\
\hline$H L A-C$ & 6.23 & 6.90 & 8.87 & 0.53 \\
\hline
\end{tabular}

Os resultados mostram ainda que a média de $\omega_{A R S}$ tende a aumentar, enquanto que média de $\omega_{(n \tilde{a} o-A R S)}$ tende a diminuir, na medida em que aumenta o nível de divergência entre os pares de 
alelos (tabela 6). No caso da base de dados não-ARS, essa observação é esperada, uma vez que o $d_{S}$ usado como medida de divergência é também o denominador de $\omega_{(n \tilde{a} o-A R S)}$. Já no caso da base de dados ARS, a tendência de $\omega$ de aumentar ao longo dos quartis de divergência merece ser investigada (ver a figura 8 e a figura 11 na página 46, para $H L A$ - $A$; a figura 9 na página 44 e a figura A.1 na página 87, para $H L A-B$ e; a figura 10 na página 45 e a figura A.2 na página 87, para $H L A-C)$.
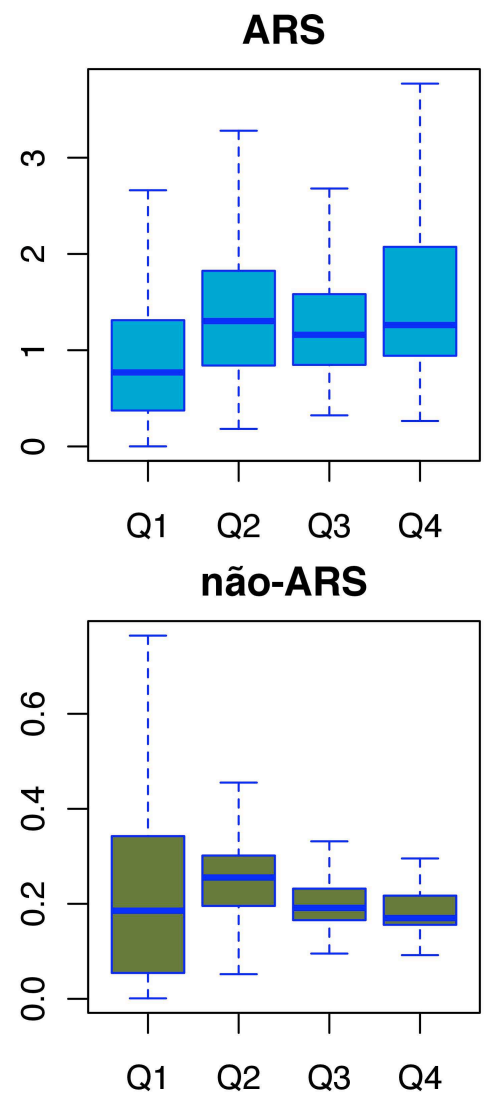

Figura 8. HLA - A: Comportamento de $\omega_{A R S}$ e $\omega_{(n \tilde{a} o-A R S)}$ ao longo dos quartis de divergência alélica. Q1-Q4 indicam quartis em ordem crescente de divergência. 
Tabela 6. Estimativas de parâmetros das análises par-a-par

\begin{tabular}{|c|c|c|c|c|c|c|c|c|c|}
\hline Loco & Quartil & $d_{N(n \tilde{a} o-A R S)}$ & $d_{S(n \tilde{a} o-A R S)}$ & $\omega_{n \tilde{a} o-A R S}$ & $d_{N(n \tilde{a} o-A R S)}>d_{S(n \tilde{a} o-A R S)}$ & $d_{N(A R S)}$ & $d_{S(A R S)}$ & $\omega_{A R S}$ & $d_{N(A R S)}>d_{S(A R S)}$ \\
\hline \multirow[t]{5}{*}{$H L A-A$} & & 0.01 & 0.07 & 0.23 & $1026 / 18336(5.59 \%)^{*}$ & 0.12 & 0.08 & 1.31 & $13366 / 18336(72.89 \%)$ \\
\hline & 1 & 0.01 & 0.02 & 0.31 & $1026 / 4596$ & 0.06 & 0.047 & 0.95 & $3095 / 4596$ \\
\hline & 2 & 0.02 & 0.06 & 0.25 & $0 / 4572$ & 0.13 & 0.076 & 1.41 & $3664 / 4584$ \\
\hline & 3 & 0.02 & 0.09 & 0.21 & $0 / 4584$ & 0.14 & 0.11 & 1.26 & $2987 / 4584$ \\
\hline & 4 & 0.02 & 0.12 & 0.18 & $0 / 4584$ & 0.15 & 0.08 & 1.57 & $3620 / 4584$ \\
\hline \multirow[t]{5}{*}{$H L A-B$} & & 0.01 & 0.05 & 0.27 & $2092 / 70125(2.98 \%)$ & 0.13 & 0.11 & 1.22 & $44460 / 70125(63.4 \%)$ \\
\hline & 1 & 0.01 & 0.02 & 0.39 & $2092 / 17772$ & 0.1 & 0.09 & 1.05 & $11195 / 17772$ \\
\hline & 2 & 0.01 & 0.04 & 0.27 & $0 / 17325$ & 0.13 & 0.13 & 1.11 & $9758 / 17325$ \\
\hline & 3 & 0.01 & 0.06 & 0.22 & $0 / 17567$ & 0.15 & 0.13 & 1.22 & $10666 / 17567$ \\
\hline & 4 & 0.01 & 0.08 & 0.19 & $0 / 17461$ & 0.16 & 0.11 & 1.48 & $12841 / 17461$ \\
\hline \multirow[t]{5}{*}{$H L A-C$} & & 0.01 & 0.05 & 0.23 & $113 / 4095(2.76 \%)$ & 0.07 & 0.03 & 1.15 & $3216 / 4095(78.53 \%)$ \\
\hline & 1 & 0.004 & 0.015 & 0.29 & $113 / 1025$ & 0.05 & 0.03 & 0.98 & $737 / 1025$ \\
\hline & 2 & 0.01 & 0.05 & 0.21 & 0/1023 & 0.07 & 0.03 & 1.00 & $802 / 1023$ \\
\hline & 3 & 0.01 & 0.07 & 0.21 & $0 / 1068$ & 0.08 & 0.03 & 1.35 & $883 / 1068$ \\
\hline & 4 & 0.02 & 0.09 & 0.21 & $0 / 979$ & 0.08 & 0.04 & 1.22 & $794 / 979$ \\
\hline
\end{tabular}

A descrição sobre como foi feita a divisão dos pares em quartis está no texto (subseção 4.5).

Os números em negrito referem-se aos valores obtidos a partir da média de todos os pares.

* O valor antes da barra corresponde aos casos em que $d_{N}>d_{S}$ e o valor após a barra corresponde ao total de pares no quartil.

As porcentagens correspondem à proporção de pares em que $d_{N}>d_{S}$ em relação ao número total de pares. 

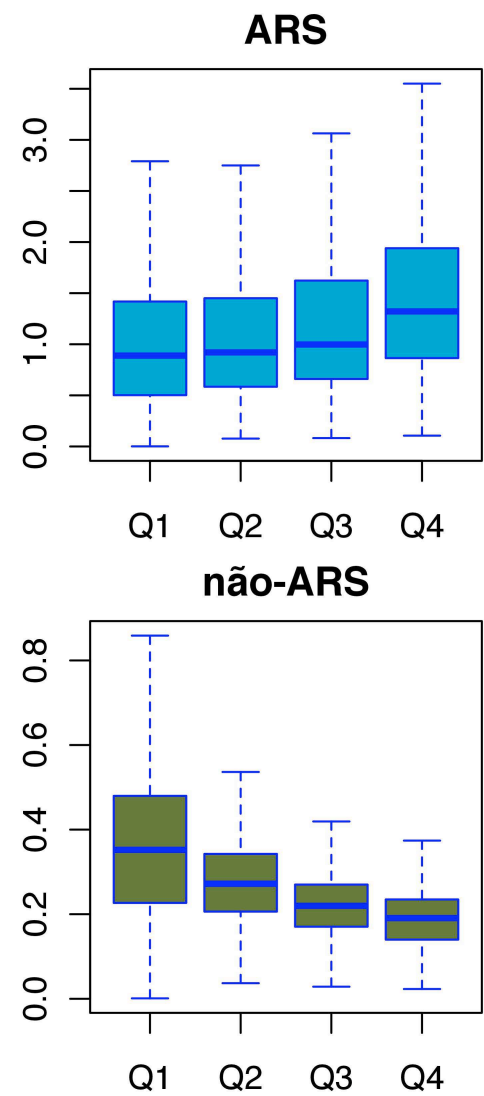

Figura 9. HLA - B: Comportamento de $\omega_{A R S}$ e $\omega_{(n \tilde{a} o-A R S)}$ ao longo dos quartis de divergência alélica. Q1-Q4 indicam quartis em ordem crescente de divergência. 

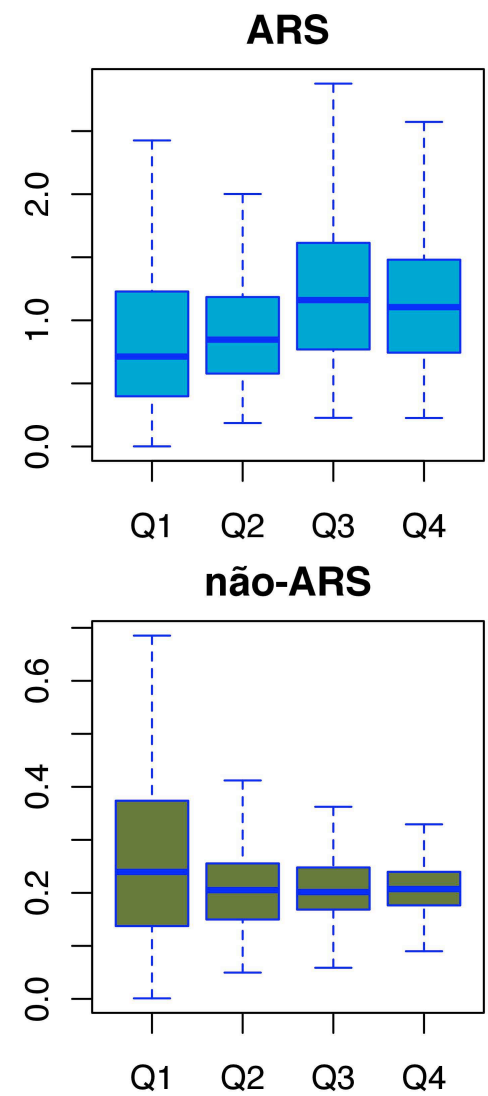

Figura 10. HLA - C: Comportamento de $\omega_{A R S}$ e $\omega_{(n \tilde{a} o-A R S)}$ ao longo dos quartis de divergência alélica. Q1-Q4 indicam quartis em ordem crescente de divergência.

Nos três locos o último quartil de divergência possui uma média de $\omega_{A R S}$ maior do que a do primeiro (o inverso ocorre para $\omega_{(n \tilde{a} o-A R S)}$, nosso controle). De forma análoga, nos três locos o número de pares com $d_{N(A R S)}>d_{S(A R S)}$ é sempre maior no último quartil (maior divergência) do que no primeiro (menor divergência), sendo que o número de pares tende a aumentar gradativamente ao longo dos quartis de divergência, com raras exceções (ver tabela 6 na página 43). 


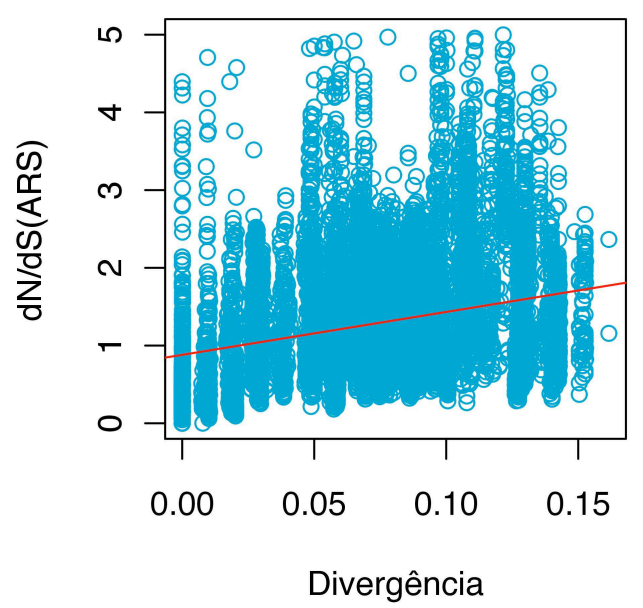

Figura 11. HLA-A: Relação entre $\omega_{A R S}$ e $d_{S(n \tilde{a} o-A R S)}$. A linha vermelha representa a regressão linear $\left(R^{2}=0.07\right)$ entre as variáveis.

A fim de testar se, de fato, existe uma correlação entre $\omega_{A R S}$ e tempo de divergência dos alelos, fizemos um teste de Mantel (1967). O teste de Mantel, ao contrário da análise de correlação linear paramétrica comumente usada, é um teste não-paramétrico baseado em permutações das matrizes de distância a serem comparadas. A figura A.6 na página 91 (anexos) mostra a distribuição dos valores de correlação e a posição da correlação empírica encontrada para o loco $H L A-A$.

Nos três locos, a correlação encontrada no teste de Mantel foi estatisticamente significativa $(p-\text { valor }<0.01)^{45}$, conforme mostra a tabela 7 na página seguinte.

Por fim, comparamos as médias de $\omega_{A R S}$ entre pares "I" e "E". A abordagem utilizada foi a de um teste não-paramétrico de comparação de médias, conforme descrito na página 33 . Em todos os locos, as diferenças entre as médias para as duas categorias foram significativas $(p-$ valor $<0.01)$, conforme mostra a tabela 8 na próxima página.

Nos LRTs, poucos pares, em cada loco, favoreceram o modelo de um $\omega$ estimado para todos os códons em relação ao modelo nulo $(\omega=1)\left(\chi_{5 \%}^{2}=3.84\right)^{46}-5.79 \%$ do total de pares para $H L A-A$, $4.38 \%$ para $H L A-B$ e $0.46 \%$ para $H L A-C$ (ver figura 12 na página 48 ).

O LRT foi feito para os valores estimados por GY94 e foi constatado que há pares de alelos que desviam de modo significativo de $\omega=1$, mas isso não se dá no sentido de $\omega>1$. De fato, de todos os pares com LRT significativo, $\omega_{A R S}=N A^{47}$ (grande maioria dos casos) ou $\omega_{A R S}<1$.

\footnotetext{
${ }^{45} \mathrm{O} p$-valor, nesse caso, foi calculado em função dos valores de correlação obtidos através das permutações das matrizes.

${ }^{46}$ Significância ao nível de $5 \%$ em uma distribuição qui-quadrado com 1 grau de liberade $(g . l)$.

${ }^{47}$ Lembrando que na 4.5 na página 32 descrevemos a forma como aplicamos filtros para lidar com valores altos de
} 
Ou seja, mesmo nos casos em que $\omega>1$, a verossimilhança do modelo com $\omega$ estimado não foi significativamente maior do que a estimada no modelo com $\omega=1$ (fixo), mas, em alguns casos em que $\omega<1$, houve signficância no teste (ver figura 12 na página seguinte).

Resumindo, através das análises par-a-par, foi possível constatar um número considerável de pares em que $\omega_{A R S}>1$; todavia, o LRT para esses mesmos pares não detectou desvios em relação ao modelo nulo.

Tabela 7. Teste de Mantel entre $\omega_{A R S}$ e e $d_{S(n \tilde{a} o-A R S)}$

\begin{tabular}{ccc}
\hline Loco & Correlação & $p-$ valor \\
\hline$H L A-A$ & 0.264 & $0.000^{* *}$ \\
$H L A-B$ & 0.228 & $0.000^{* *}$ \\
$H L A-C$ & 0.181 & $0.000^{* *}$ \\
\hline
\end{tabular}

Os valores inexistentes (NA) foram tratados por deleção de pares (casewise deletion) contendo NAs. A significância não mudou quando os NAs foram tratados com imputação da média global (overall mean imputation). Correlação, índice de correlação de Pearson; a significância do teste não mudou quando foram utilizados os índices de correlação de Spearman ou Kendall; **, denota significância ao nível de $1 \%$.

Pudemos concluir, portanto, com base nas análises par-a-par, que existe uma correlação positiva entre $\omega_{A R S}$ e tempo de divergência dos alelos, indicando que alelos mais divergentes têm maior $\omega_{A R S}$. A fim de verificar se tal correlação poderia ser causada como artefato dos métodos de estimação de $d_{N}$ e $d_{S}$ utilizados, foram feita uma simulação, descrita na subseção 4.6 na página 34 .

Tabela 8. Valores de $\omega_{A R S}$ para pares "I" e "E"

\begin{tabular}{ccccc}
\hline Loco & $\omega_{A R S}(\mathrm{I})$ & $\omega_{A R S}(\mathrm{E})$ & T de Student & $p-$ valor \\
\hline$H L A-A$ & 0.47 & 1.37 & 58.14 & $0.000^{* *}$ \\
$H L A-B$ & 0.74 & 1.25 & 52.32 & $0.000^{* *}$ \\
$H L A-C$ & 1.11 & 1.20 & 3.15 & $0.000137^{* *}$ \\
\hline
\end{tabular}

*, denota significância ao nível de 5\%;**, denota significância ao nível de 1\%; T de Student, refere-se às comparações de médias de $\omega$ para pares "I" (intra-linhagens) e "E" (entre-linhagens).

Nossa simulação, feita apenas para o loco $H L A$ - $A$, consistiu em simular 100 bases de dados ARS e 100 não-ARS (ambas condicionadas à topologia filogenética fornecida pela base de dados não-ARS) a fim de calcular as correlações entre $\omega_{A R S}$ e o tempo de divergência dos alelos. Os parâmetros $\omega$, os quais foram tratados como NAs. 


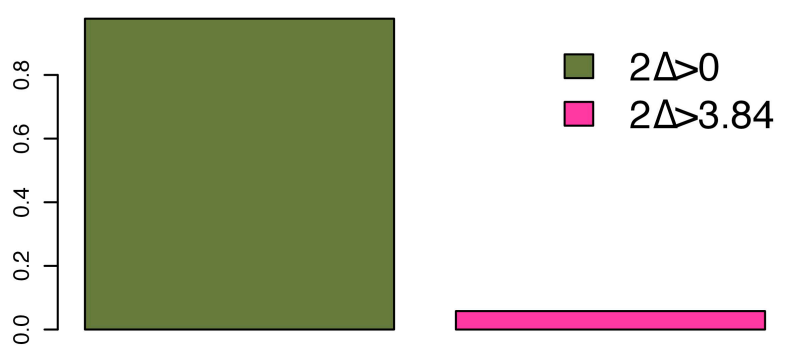

HLA-A

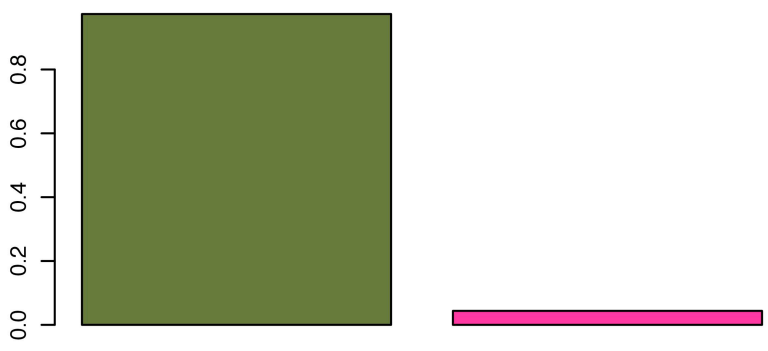

HLA-B

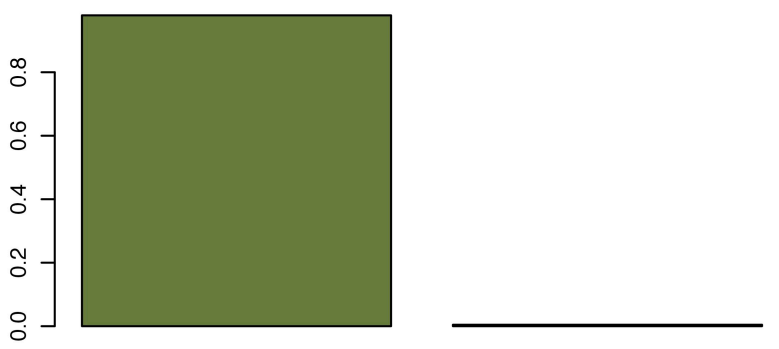

HLA-C

Figura 12. LRT para análises par-a-par. As barras mostram a proporção de pares em cada loco em que $2 \Delta l>0$ (verde-escuro) ou $2 \Delta l>3.84$ (rosa). Em todos os casos em que $2 \Delta l>3.84, \omega_{A R S}<1$ ou $\omega_{A R S}=N A$. Em nenhum dos casos $\omega_{A R S}>1$. 


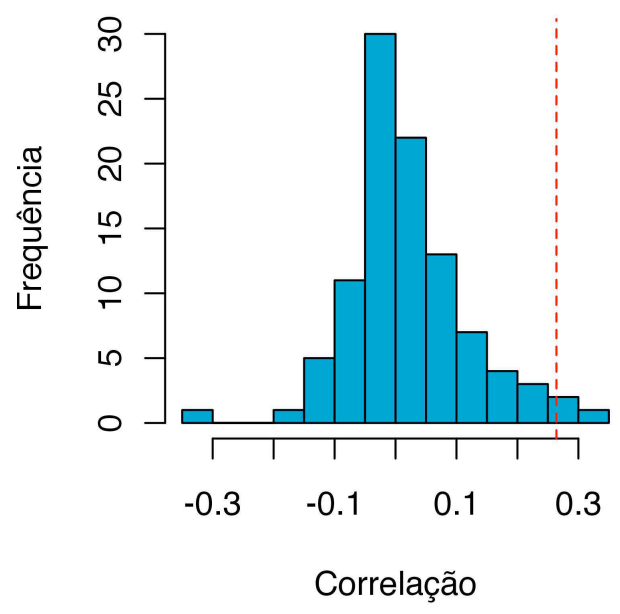

Figura 13. Histograma de valores de correlação para bases de dados simuladas de $\boldsymbol{H} \boldsymbol{L} \boldsymbol{A}-\boldsymbol{A}$. As variáveis correlacionadas foram $\omega_{A R S}$ e $d_{S(n \tilde{a} o-A R S)}$, simuladas 100 vezes cada. A linha vermelha mostra a inserção da correlação empírica nessa distribuição.

utilizados na simulação foram os mesmos obtidos pelos dados empíricos, conforme exposto na subseção 4.6 na página 34. A figura 13 mostra um histograma desses valores de correlação para bases de dados simuladas e o ponto dessa distribuição em que se insere o valor de correlação empírico encontrado para $H L A-A$. O $p$-valor $=0.022$ está situado entre dois valores de significância comumente aceitos na literatura (5 e 1\%). Desta forma é encontrada uma significância, no valor de correlação empírico entre $\omega_{A R S}$ e $d_{S(n \tilde{a} o-A R S)}$, e concluímos que a correlação empírica obtida entre $\omega_{A R S}$ e $d_{S(n \tilde{a} o-A R S)}$ no loco $H L A-A$ é maior do que a esperada sob o modelo nulo que criamos . 


\section{Análises filogenéticas}

\subsection{Determinação de sítios sob seleção positiva}

A abordagem adotada nessa etapa de análises foi semelhante àquela de Yang e Swanson (2002) e de Furlong e Yang (2008). Estimativas de máxima verossimilhança sob diversos modelos de seleção sobre códons estão listados na tabela 11 na página 53 para $H L A$ - $A$, na tabela 12 na página 54 para $H L A-B$ e na tabela 13 na página 55 para $H L A-C$. Os valores mostrados nessas tabelas referem-se às bases de dados CR. As tabelas equivalentes para as bases de dados SR são a tabela 14 na página 56, a tabela 15 na página 57 e a tabela 16 na página 58.

Para os três locos $H L A-A$ e $H L A-B$, em ambas as comparações (M1 versus M2; M7 versus M8), o LRT $\left(\chi_{1 \%}^{2}=9.21,2 g . l\right)$ favoreceu o modelo que incorpora uma categoria de sítios sob seleção (M2 em relação ao M1 ou M8 em relação ao M7) na base de dados CR (tabela 9 na página seguinte). Nas bases de dados SR obtivemos resultados qualitativamente semelhantes, embora haja uma tendência geral de diminuição da diferença entre os logs das verossimilhanças dos modelos (tabela 10 na página 52).

48.

Dado que M8 foi favorecido em todos os locos, comparamos os códons com evidência de seleção em M8 nas bases de dados CR e SR. Na base de dados $H L A$-A, os códons 82, 95 e 116 aparecem como selecionados em CR, mas não na SR. Por fim, o códon 167 aparece como selecionado em SR, mas não em CR (tabelas 11 na página 53 e 16 na página 58).

Para $H L A-B$, o códon 94 aparece como selecionado em CR, mas não em SR. Já os os códons 9 , 11, 12, 83, 99, 163, 167 e 171 aparecem como selecionadosem SR, mas não em CR (tabelas 12 na página 54 e 15 na página 57$)$.

Em $H L A-C$ a única diferença entre as bases de dados foi que o códon 152 aparece como selecionado apenas em SR (tabelas 13 na página 55 e 16 na página 58.

Percebemos que, ao menos em alguns desses casos de códons conflitantes nas bases de dados com e sem recombinantes, os códons conflitantes não foram detectados como selecionados devido ao limiar de probabilidade que adotamos $(P>95 \%$ ou $P>99 \%)$ ser bastante conservador.

A opção de fazer as análises para bases de dados CR e SR foi motivada pela necessidade de investigar o efeito que os eventos de recombinação poderiam ter. Concluímos, portanto, que a

\footnotetext{
${ }^{48} 999$ é o limite máximo estabelecido pelo PAML. O valor é o resultado de um número positivo dividido por 0. Esse tipo de valor é encontrado quando há uma substituição não-sinônima no ramo, mas nenhuma subsituição sinônima (ver página 33). Embora o valor seja extremo, ele foi gerado por apenas uma subsituição e, portanto, não é indicativo de seleção. O fato de, além de não ter sido significativa, a estatística do LRT ter sido negativa, é devido a restrições aos possíveis valores dos parâmetros no programa. Na prática, $2\left(l_{1}-l_{0}\right)<0$ tem o mesmo significado que $2\left(l_{1}-l_{0}\right)=0$.
} 
Tabela 9. LRT entre os modelos de seleção sobre códons (CR)

\begin{tabular}{ccccccccccc}
\hline Loco & $l_{1}$ & $l_{2}$ & $n p_{1}$ & $n p_{2}$ & $2\left(l_{2}-l_{1}\right)$ & $l_{7}$ & $l_{8}$ & $n p_{7}$ & $n p_{8}$ & $2\left(l_{8}-l_{7}\right)$ \\
\hline$H L A-A$ & -4361.10 & -4217.16 & 288 & 290 & $287.88^{* *}$ & -4374.67 & -4218.533 & 288 & 290 & $312.27^{* *}$ \\
$H L A-B$ & -6968.83 & -6625.44 & 466 & 468 & $686.78^{* *}$ & -6983.3 & -6631.67 & 466 & 468 & $703.26^{* *}$ \\
$H L A-C$ & -3634.59 & -3562.2 & 266 & 268 & $144.78^{* *}$ & -3636.53 & -3562.73 & 266 & 268 & $147.6^{* *}$ \\
\hline
\end{tabular}

$l_{1}, \log$ da máxima verossimilhança de M1 (o mesmo vale para os modelos 2,7 e 8 ); $n p_{1}$, número de parâmetros

estimados sob M1 (o mesmo vale para os modelos 2,7 e 8$)$; *denota significância $\left(\chi_{5 \%}^{2}=5.99,2 g . l\right)$; **denota

forte significância $\left(\chi_{1 \%}^{2}=9.21,2 g . l\right)$. 
Tabela 10. LRT entre os modelos de seleção sobre códons (SR)

\begin{tabular}{ccccccccccc}
\hline Loco & $l_{1}$ & $l_{2}$ & $n p_{1}$ & $n p_{2}$ & $2\left(l_{2}-l_{1}\right)$ & $l_{7}$ & $l_{8}$ & $n p_{7}$ & $n p_{8}$ & $2\left(l_{8}-l_{7}\right)$ \\
\hline$H L A-A$ & -3670.42 & -3580.17 & 214 & 216 & $180.5^{* *}$ & -3676.239 & -3580.79 & 214 & 216 & $190.9^{* *}$ \\
$H L A-B$ & -3537.14 & -3386.90 & 156 & 158 & $300.48^{* *}$ & -3541.58 & -3386.57 & 156 & 158 & $310.02^{* *}$ \\
$H L A-C$ & -3256.94 & -3204.49 & 218 & 220 & $104.9^{* *}$ & -3257.87 & -3204.66 & 218 & 220 & $106.42^{* *}$ \\
\hline
\end{tabular}

$l_{1}, \log$ da máxima verossimilhança de M1 (o mesmo vale para os modelos 2,7 e 8 ); $n p_{1}$, número de parâmetros estimados sob M1 (o mesmo vale para os modelos 2,7 e 8$) ;{ }^{*}$ denota significância $\left(\chi_{5 \%}^{2}=5.99,2 g . l\right) ;{ }^{* *}$ denota forte significância $\left(\chi_{1 \%}^{2}=9.21,2 g . l\right)$. 
Tabela 11. Estimativas de parâmetros sob modelos de seleção sobre códons para $H L A-A$ (CR)

\begin{tabular}{|c|c|c|c|}
\hline Modelo & $l$ & Estimativas de parâmetros & Sítios selecionados positivamente \\
\hline M0 & -4546.89 & $\omega=0.96$ & Nenhum \\
\hline M1 & -4361.10 & $p_{0}=0.80,\left(p_{1}=0.2\right), \omega=0.06, \omega_{1}=1$ & Não permitido \\
\hline M2 & -4217.16 & $\begin{array}{c}p_{0}=0.68, p_{1}=0.25,\left(p_{2}=0.07\right) \\
\omega_{0}=0.08, \omega_{1}=1, \omega_{2}=9.12\end{array}$ & $\begin{array}{c}\text { 9F, 62Q, 63E, 66N, 70H, 76A, 77N,81L, } \\
82 \mathrm{R}, 97 \mathrm{I}, 99 \mathrm{Y}, 114 \mathrm{R}, 151 \mathrm{H}, 152 \mathrm{~A}, 156 \mathrm{R}, 163 \mathrm{R}\end{array}$ \\
\hline M7 & -4374.67 & $p=0.08, q=0.20$ & Não permitido \\
\hline M8 & -4218.53 & $\begin{array}{c}p_{0}=0.93, p=0.09, q=0.16 \\
p_{1}=0.07, \omega_{s}=9.44\end{array}$ & $\begin{array}{c}\text { 9F,62Q,63E,66N,70H,76A,77N,81L,82R,95I, } \\
\text { 97I,99Y,114R,116D,151H,152A,156R,163R }\end{array}$ \\
\hline
\end{tabular}

Nota: os sítios selecionados positivamente pelo método (BEB) foram identificados com o limiar de $p>95 \%$, sendo que aqueles com $p>99 \%$ estão em negrito. Estimativas de $\kappa$ variaram de 1.69 a 1.98 entre os modelos.

$p_{0}, p_{1}$ e $p_{2}$, proporções de sítios com certo valor de $\omega ; \omega, \omega_{0}, \omega_{1}$ e $\omega_{3}$, valores de $\omega$ para cada categoria de sítios; $p$ e $q$,

parâmetros que dão forma à distribuição beta do M7; $\omega_{s}$, valor de $\omega$ estimado a partir dos dados no M8. 
Tabela 12. Estimativas de parâmetros sob modelos de seleção sobre códons para $H L A-B(\mathrm{CR})$

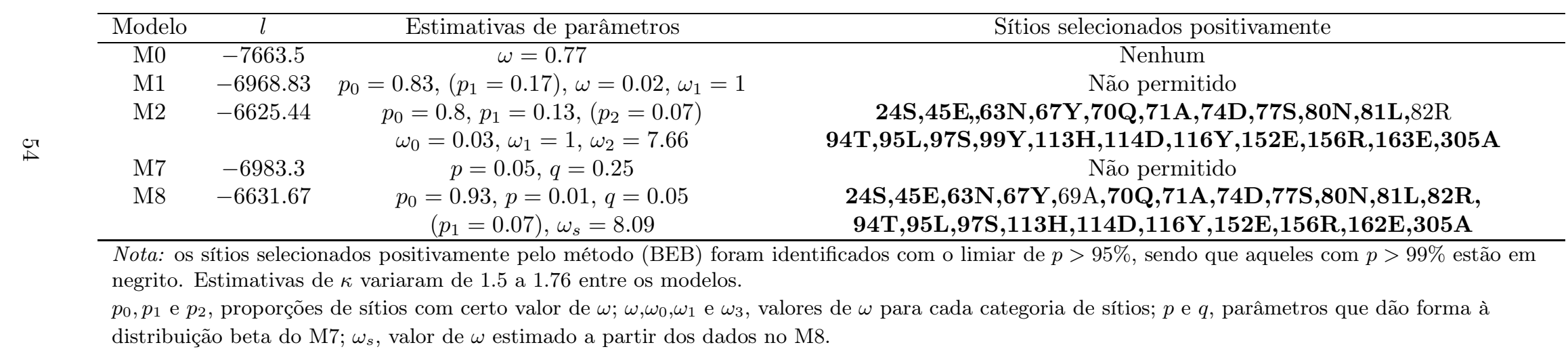


Tabela 13. Estimativas de parâmetros sob modelos de seleção sobre códons para $H L A-C$ (CR)

\begin{tabular}{|c|c|c|c|}
\hline Modelo & $l$ & Estimativas de parâmetros & Sítios selecionados positivamente \\
\hline M0 & -3737.28 & $\omega=0.73$ & Nenhum \\
\hline M1 & -3634.59 & $p_{0}=0.74,\left(p_{1}=0.26\right), \omega=0.05, \omega_{1}=1$ & Não permitido \\
\hline M2 & -3562.2 & $\begin{array}{c}p_{0}=0.65, p_{1}=0.32,\left(p_{2}=0.03\right) \\
\omega_{0}=0.03, \omega_{1}=1, \omega_{2}=9.82\end{array}$ & 9F,24S,73T,77S,80N,99C,116Y,156R,163T \\
\hline M7 & -3636.53 & $p=0.01, q=0.02$ & Não permitido \\
\hline M8 & -3562.73 & $\begin{array}{c}p_{0}=0.097, p=0.005, q=0.01 \\
\left(p_{1}=0.03\right), \omega_{S}=10.47\end{array}$ & 9F,24S,73T,77S,80N,99C,116Y,156R,163T \\
\hline
\end{tabular}

Nota: os sítios selecionados positivamente (BEB) foram identificados com o limiar de $p>95 \%$, sendo que aqueles com $p>99 \%$ estão em negrito. Estimativas de $\kappa$ variaram de 2.56 a 2.87 entre os modelos. $p_{0}, p_{1}$ e $p_{2}$, proporções de sítios com certo valor de $\omega ; \omega, \omega_{0}, \omega_{1}$ e $\omega_{3}$, valores de $\omega$ para cada categoria de sítios; $p$ e $q$, parâmetros que dão forma à distribuição beta do M7; $\omega_{s}$, valor de $\omega$ estimado a partir dos dados no M8. 
Tabela 14. Estimativas de parâmetros sob modelos de seleção sobre códons para $H L A-A$ (SR)

\begin{tabular}{|c|c|c|c|}
\hline Modelo & $l$ & Estimativas de parâmetros & Sítios selecionados positivamente \\
\hline M0 & -3779.65 & $\omega=1.96170$ & Nenhum \\
\hline M1 & -3670.42 & $p_{0}=0.76,\left(p_{1}=0.24\right), \omega=0.06, \omega_{1}=1$ & Não permitido \\
\hline M2 & -3580.17 & $\begin{array}{c}p_{0}=0.63, p_{1}=0.30,\left(p_{2}=0.07\right) \\
\omega_{0}=0.09, \omega_{1}=1, \omega_{2}=8.54\end{array}$ & $\begin{array}{l}\text { 9F,62Q,63E,66N,70H,76A,77N,81L,97I, } \\
\text { 99Y,114R,151H,152A,156R,163D, 167G }\end{array}$ \\
\hline M7 & -3676.24 & $p=0.02, q=0.03$ & Não permitido \\
\hline M8 & -3580.79 & $\begin{array}{c}p_{0}=0.93, p=0.02, q=0.03 \\
\quad\left(p_{1}=0.07\right), \omega_{s}=9.11\end{array}$ & $\begin{array}{c}\text { 9F,62Q,63E,66N,70H,76A,77N, } \\
\text { 81L,97I,99Y,114R,151H,152A,156R,163R, 167G }\end{array}$ \\
\hline
\end{tabular}

Nota: os sítios selecionados positivamente (BEB) foram identificados com o limiar de $p>95 \%$, sendo que aqueles

com $p>99 \%$ estão em negrito. Estimativas de $\kappa$ variaram de 1.74 a 2.04 entre os modelos.

$p_{0}, p_{1}$ e $p_{2}$, proporções de sítios com certo valor de $\omega ; \omega, \omega_{0}, \omega_{1}$ e $\omega_{3}$, valores de $\omega$ para cada categoria de sítios; $p$ e $q$,

parâmetros que dão forma à distribuição beta do M7; $\omega_{s}$, valor de $\omega$ estimado a partir dos dados no M8. 
Tabela 15. Estimativas de parâmetros sob modelos de seleção sobre códons para $H L A-B$ (SR)

\begin{tabular}{|c|c|c|c|}
\hline Modelo & $l$ & Estimativas de parâmetros & Sítios selecionados positivamente \\
\hline M0 & -3782.43 & $\omega=0.86$ & Nenhum \\
\hline M1 & -3537.145 & $p_{0}=0.835,\left(p_{1}=0.165\right), \omega=0.02, \omega_{1}=1$ & Não permitido \\
\hline M2 & -3386.91 & $\begin{array}{c}p_{0}=0.77, p_{1}=0.14,\left(p_{2}=0.09\right) \\
\omega_{0}=0.02, \omega_{1}=1, \omega_{2}=9.64\end{array}$ & $\begin{array}{l}\text { 9Y,11S,12V,24S,45E,63N,67Y,70Q,71A,74D,77S,80N,81L,82R, } \\
\text { 83G,95L,97S,99Y,113H,114D,116Y,152E,156R,163E,171Y,305A }\end{array}$ \\
\hline M7 & -3541.58 & $p=0.01, q=0.08$ & Não permitido \\
\hline M8 & -3386.57 & $\begin{array}{l}p_{0}=0.91 p=0.03 q=0.14 \\
\quad\left(p_{1}=0.09\right) \omega_{s}=9.48\end{array}$ & $\begin{array}{c}\text { 9Y,11S,12V,24S,45E,63N,67Y,69A,70Q,71A,74D,77S,80N,81L,82R, } \\
\text { 83G,95L,97S,99Y,113H,114D,116Y,152E,156R,163E, 167W,171Y,305A }\end{array}$ \\
\hline
\end{tabular}

Nota: os sítios selecionados positivamente pelo (BEB) foram identificados com o limiar de $p>95 \%$, sendo que aqueles com $p>99 \%$ estão em negrito.

Estimativas de $\kappa$ variaram de 1.47 a 1.74 entre os modelos. $p_{0}, p_{1}$ e $p_{2}$, proporções de sítios com certo valor de $\omega ; \omega, \omega_{0}, \omega_{1}$ e $\omega_{3}$, valores de $\omega$ para

cada categoria de sítios; $p$ e $q$, parâmetros que dão forma à distribuição beta do M7; $\omega_{s}$, valor de $\omega$ estimado a partir dos dados no M8. 
Tabela 16. Estimativas de parâmetros sob modelos de seleção sobre códons para $H L A-C$ (SR)

Sítios selecionados positivamente

\begin{tabular}{|c|c|c|c|}
\hline Modelo & $l$ & Estimativas de parâmetros & Sítios selecionados positivamente \\
\hline M0 & -3327.41 & $\omega=0.74$ & Nenhum \\
\hline M1 & -3256.94 & $p_{0}=0.69,\left(p_{1}=0.31\right), \omega=0.04, \omega_{1}=1$ & Não permitido \\
\hline M2 & -3204.49 & $\begin{array}{c}p_{0}=0.58, p_{1}=0.37,\left(p_{2}=0.05\right) \\
\omega_{0}=0.02, \omega_{1}=1, \omega_{2}=8.59\end{array}$ & 9F,24S,73T,77S,80N,99C,116Y,156R,163T \\
\hline M7 & -3257.87 & $p=0.015, q=0.03$ & Não permitido \\
\hline M8 & -3204.66 & $\begin{array}{c}p_{0}=0.95, p=0.005, q=0.01 \\
\left(p_{1}=0.05\right), \omega_{s}=8.83\end{array}$ & 9F,24S,73T,77S80N,99C,116Y,152E,156R,163T \\
\hline
\end{tabular}

Nota: os sítios selecionados positivamente pelo método (BEB) foram identificados com o limiar de $p>95 \%$, sendo que

aqueles com $p>99 \%$ estão em negrito. Estimativas de $\kappa$ variaram de 2.48 a 2.77 entre os modelos. $p_{0}, p_{1}$ e $p_{2}$, proporções

de sítios com certo valor de $\omega ; \omega, \omega_{0}, \omega_{1}$ e $\omega_{3}$, valores de $\omega$ para cada categoria de sítios; $p$ e $q$, parâmetros que dão forma à

distribuição beta do M7; $\omega_{s}$, valor de $\omega$ estimado a partir dos dados no M8. 
presença ou ausência de recombinantes parece afetar um pouco a identificação de sítios sob seleção positiva e tendeu a diminuir os valores da estatística do LRT nas bases de dados SR. É esperado que a presença de recombinantes possa afetar a detecção de sítios sob seleção (via BEB $^{49}$ ) e os resultados de LRTs, muitas vezes aumentando a probabilidade de erros do tipo I (rejeição da hipótese nula quando ela é verdadeira) (Anisimova et al., 2003). Como os LRTs foram também significativos para as bases de dados SR (salvo para M8xM2 em $H L A-C$, conforme discutimos) e, de forma geral, houve bastante congruências entre os resultados obtidos em ambas as bases de dados, acreditamos ter documentado a robustez da detecção dos sítios selecionados e da significância dos LRTs.

Na discussão que segue, sobre comparações entre classificações de códons ARS, os códons considerados como "selecionados" foram aqueles obtidos pelo M8 nas bases de dados CR.

\subsection{Comparação entre classificações de códons baseadas em estrutura molecular e evidências de seleção}

Comparamos a classificação de códons ARS proposta por Bjorkman et al. (1987) - e utilizada no clássico estudo de Hughes e Nei (1988) de seleção sobre os códons ARS -, a classificação proposta por Chelvanayagam (1996) - e adotada no presente estudo na etapa par-a-par -, o estudo de Yang e Swanson (2002) sobre pressões seletivas diferentes sobre diferentes códons e a abordagem aqui adotada, muito semelhante à de Yang e Swanson.

A razão para essa comparação é simples: conforme argumentamos na introdução, as evidências sobre seleção sobre códons ARS já foram documentadas para os locos de $H L A$ de classe I (Hughes e Nei, 1988). No presente estudo buscamos avaliar a importância de dois alvos de seleção (alelos individuais e linhagens alélicas) na evolução dos genes $H L A$. Para tanto, partimos da premissa de que códons ARS são selecionados positivamente e que esse conjunto de códons seria informativo para os nossos propósitos.

O estudo de Yang e Swanson (2002) mostrou haver uma considerável (porém não completa) sobreposição entre códons ARS e códons com evidência de seleção positiva. Sendo assim, consideramos importante avaliar a sobreposição de códons com evidência de seleção e os códons ARS. Adotamos praticamente a mesma metodologia de Yang e Swanson, com uma importante diferença: analisamos cada loco de classe I separadamente ao passo que esses autores alinharam sequências de alelos dos três locos e os analisaram conjuntamente. Além disso, a cada ano mais alelos são incorporados às bases de dados de $H L A$, de forma que uma atualização dos resultados obtidos por Yang e Swanson é relevante. Como a deteç̧ão de sítios sob seleção varia entre estudos, em parte devido a diferenças

\footnotetext{
${ }^{49}$ Ver definição na página 39.
} 
entre as bases de dados, julgamos necessário definir sítios selecionados no contexto de nossa análise.

No caso do estudo de Yang e Swanson, foram considerados "sob seleção" os sítios com probabilidade $P>95 \%$ de estar sob seleção sob o modelo $M 8^{50}$. No nosso estudo, o critério foi o mesmo.

Embora as análises do presente estudo tenham sido feitas separadamente para cada loco, agrupamos todos os sítios sob seleção nos três locos, uma vez que as outras classificações - Chelvanayagam (1996) e Bjorkman et al. (1987) - são para classe I como um todo. Chamaremos o conjunto de códons selecionados em $H L A-A$, -B e - $C$ (sob M8, base de dados CR) de "BIT".

A classificação de Bjorkman et al. (1987) (chamaremos de "BJOR") considera 57 códons ARS e a de Chelvanayagam (1996) (chamaremos de "CHEV"), 48. Yang e Swanson (2002) encontraram 26 códons sob seleção para classe I (chamaremos esse conjunto de "YANG") e nós encontramos 30 (figura 14 na página seguinte).

A figura 14 ilustra o grau de sobreposição entre as duas classificações de códons ARS e a nossa lista de códons com evidência de seleção positiva. O grau de sobreposição dos códons sob seleção com a classificação de Chelvanayagam (1996) aumenta se a classificação adotada for uma sobreposição desta com a de Bjorkman et al. (1987). Essa observação é interessante no sentido de nos mostrar que o número de códons sob seleção positiva que são códons ARS irá aumentar se a classificação de códons ARS for mais abrangente (o que é alcançado com a fusão das duas classificações). De fato, a figura 14 mostra que 26 dos 30 códons BIT são ARS na classificação CHEV e 26 na classificação de Bjorkman et al. (1987). Quando as duas classificações são sobrepostas, 27 dos sítios BIT são ARS.

A figura 14 mostra, ainda, que apenas três códons YANG não foram detectados como positivamente selecionados também em nossa análise (ou seja, não estão em "BIT"), conforme o esperado uma vez que os métodos empregados foram bastante semelhantes.

Essas medidas mostram que existe grande sobreposição entre as duas classificações. Todavia, não há indícios de que uma ou outra definição de códons ARS seja melhor do que a outra. Ambas as classificações são baseadas na estrutura tridimensional da molécula, e não no conhecimento, $a$ priori, de pressões seletivas sobre determinados códons. Se uma proporção significativa dos códons sob seleção são códons ARS, é provavelmente porque os códons ARS estão sofrendo seleção, o que sugere que as classificações refletem unidades de seleção significativas.

Embora a classificação de Bjorkman seja mais abrangente, e i37 dos 48 códons CHEV estejam contidos em BJOR, Chelvanayagam, esta última foi preferida por ser mais recente e por levar em conta não apenas os sítios conhecidos de interação entre molécula MHC e peptídeo, mas por levar em conta também a "vizinhança" destes sítios, denominadas peptide binding environments (PBEs).

\footnotetext{
${ }^{50} \mathrm{Em}$ nossa abordagem, conforme mencionado na subseção anterior, o M8 foi favorecido nos LRTs e, por isso, utilizamos as listas de códons positivamente selecionados fornecidas por essa modelo.
} 


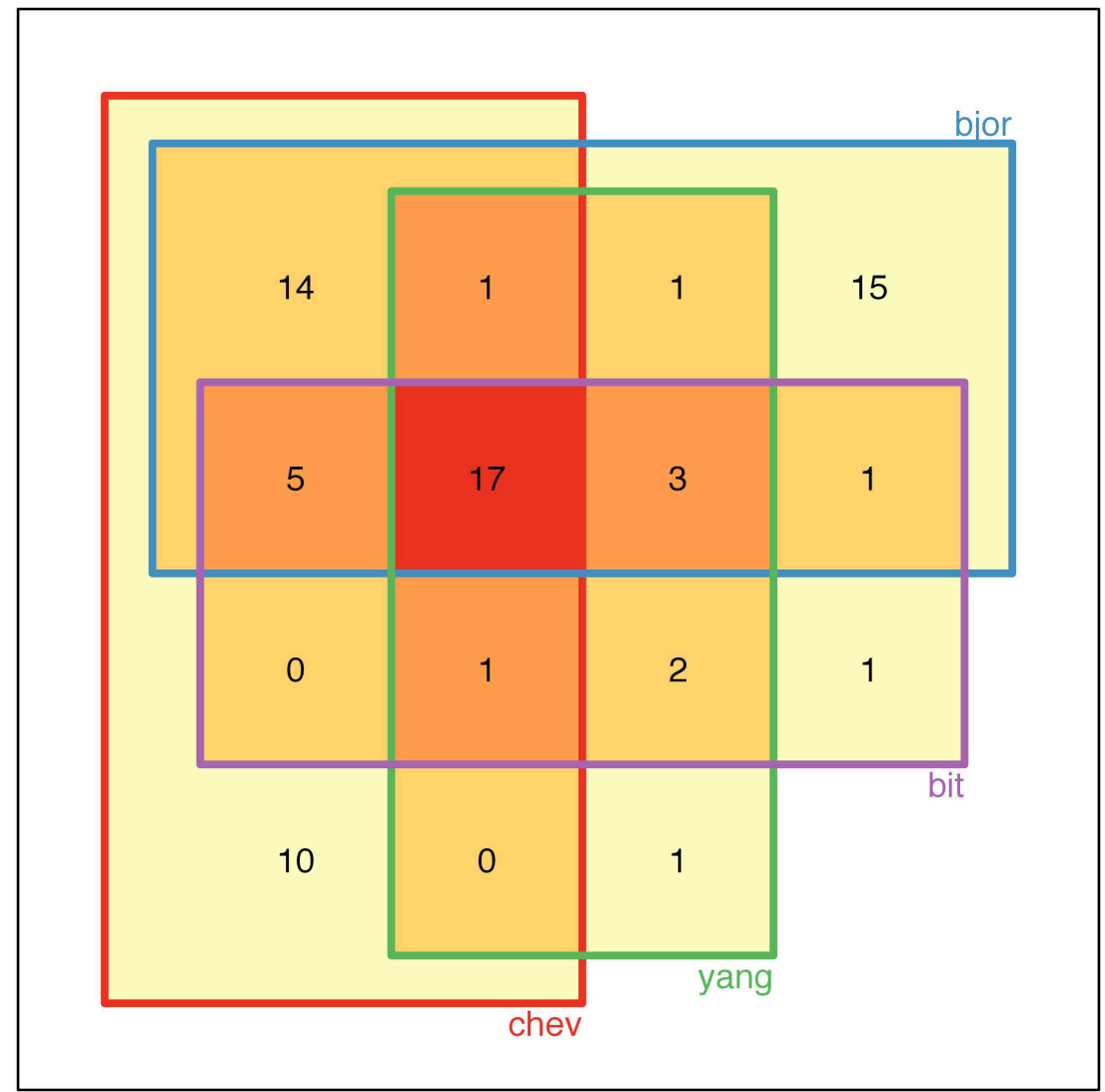

Figura 14. Comparação entre duas classificações de códons ARS e dois estudos de seleção sobre códons. Diagrama de Venn mostrando as sobreposições entre duas classificações de códons ARS (CHEV e BJOR) e dois estudos de seleção sobre códons (YANG e BIT). Explicações sobre as classificações encontram-se no texto. 
Tabela 17. Tabela de contingência entre códons BIT e códons CHEV

\begin{tabular}{ccc}
\hline & BIT & não-BIT \\
\hline CHEV & 23 & 25 \\
não-CHEV & 6 & 117 \\
$p-$ valor $<0.001^{*}$ & \\
\hline não $-C H E V$, refere-se aos códons que \\
não estão na classificação CHEV (ver texto \\
na página corrente). O $p-$ valor \\
refere-se a um teste de homogeneidade. \\
* denota forte significância $(\alpha=0.001)$
\end{tabular}

Portanto, os resultados de estimação de $d_{N}, d_{S}$ e $d_{N} / d_{S}$ para códons ARS que serão relatados na subseção 7.3 na página 64 foram obtidos usando a classificação de Chelvanayagam (1996), como fizemos nas análises par-a-par.

Duas questões surgiram após essas comparações: existem evidências de seleção positiva sobre códons vizinhos àqueles definidos como ARS? Poderíamos nos beneficiar de uma classificação CHEV "expandida", que englobasse mais sítios sob seleção positiva?

Criamos três classificações de códons "vizinhos" aos códons CHEV: (1) CHEV \pm 1 ; (2) CHEV \pm 2 e; (3) CHEV \pm 3 (códons uma, duas ou três posições antes ou depois dos códons ARS, respectivamente). Nos três casos, foram excluídos os códons presentes na classificação ARS original ${ }^{51}$. A intenção foi verificar se existem proporções consideráveis de códons BIT nas vizinhanças dos códons CHEV.

Na figura 15 na página seguinte podemos perceber que, na medida em que se incorpora códons vizinhos à classificação CHEV, diminuem os sítios BIT que não entram nas classificações. De fato, todos os códons BIT que não estão em $\mathrm{CHEV}$ estão em $\mathrm{CHEV} \pm 1$. Além disso, fica claro pelo segundo gráfico da figura que, ao considerarmos uma classificação mista, composta de CHEV+BJOR, o grau de sobreposição com códons BIT aumenta.

A fim de testar se a tendência de aumento de sobreposição entre BIT e CHEV \pm 1 é significativa, testamos a hipótese de que o aumento de sobreposição pudesse ser meramente uma consequência do fato de a classificação $\mathrm{CHEV} \pm 1$ englobar uma grande parcela dos sítios não-CHEV.

A tabela 17 mostra um teste de homogeneidade entre códons BIT e códons CHEV. A tabela 18 mostra o mesmo teste entre BIT e CHEV \pm 1 - sendo que, neste caso, os códons CHEV contidos na classificação BIT foram excluídos a priori.

O que essas análises nos mostram? Basicamente, que: (a) CHEV e BIT têm 23 códons de

\footnotetext{
${ }^{51}$ Por exemplo, o códon 5 está na classificação CHEV. Assim, os códons 4 e 6 entram na classificação CHEV \pm 1. Analogamente, os códons 2, 3, 4, 6, 7, e 8 entrariam na classificação CHEV \pm 3 . Em ambos os casos, o códon 5 não entraria nas classificações. Em resumo, a classificação CHEV \pm 3 inclui os códons de $\mathrm{CHEV} \pm 1$ e $\mathrm{CHEV} \pm 2$.
} 

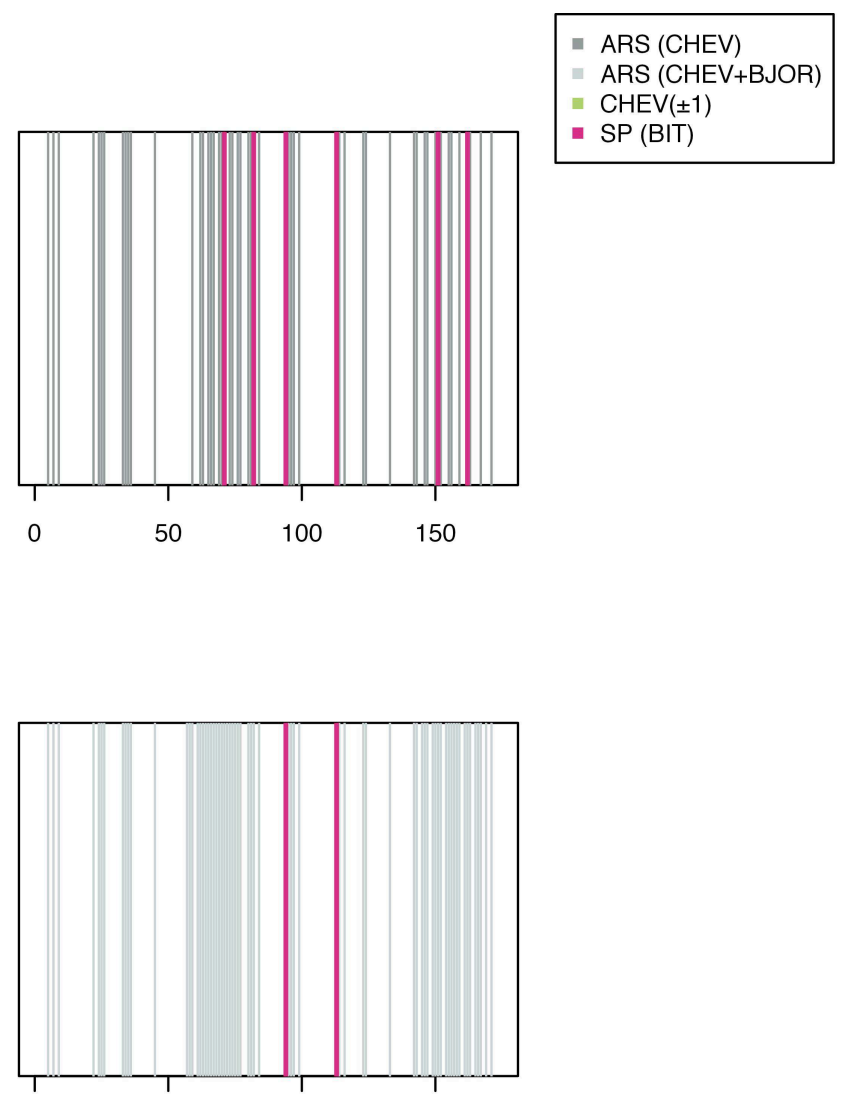

$\begin{array}{lll}0 & 50 \quad 100 \quad 150\end{array}$

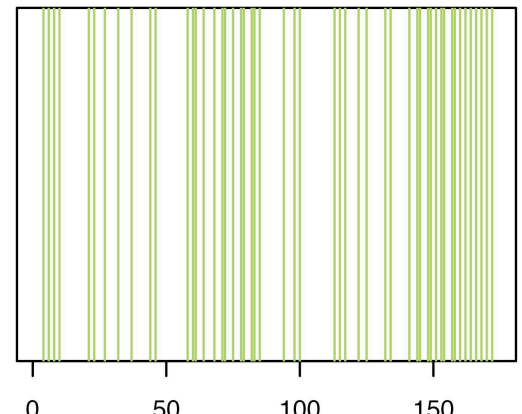

Figura 15. Seleção sobre códons vizinhos aos ARS. $A R S(C H E V)$, sítios ARS na classificação de Chelvanayagam; $A R S(B J O R+C H E V)$, sobreposição de sítios ARS das classificações de Bjorkman e de Chelvanaygam; $C H E V \pm 1$, códons uma posição antes ou depois dos códons CHEV; $S P(B I T)$, sítios sob seleção positiva (nossa abordagem). Os códons SP mostrados em cada figura são aqueles que não sobrepõem com cada uma das classificações. 
sobreposição e ela é significativa; e (b) todos os códons selecionados (BIT) estão ou contidos em CHEV (21 códons) ou estão nas vizinhanças de CHEV ( \pm 1 códon de distância) $)^{52}$.

Tabela 18. Tabela de contingência entre códons BIT e códons CHEV \pm 1

\begin{tabular}{lcc}
\hline & BIT & não-BIT \\
\hline CHEV $( \pm 1)$ & 6 & 44 \\
não-CHEV $( \pm 1)$ & 0 & 121 \\
$p-$ valor $<0.001^{*}$ & \\
\hline não - CHEV $( \pm 1)$, refere-se aos códons que \\
não estão na classificação CHEV (ver texto \\
na página 62). O $p$ - valor \\
refere-se a um teste de homogeneidade. \\
$*$ denota forte significância $(\alpha=0.001)$
\end{tabular}

Concluímos, portanto, que poderíamos aumentar nosso poder estatístico se criássemos uma lista mista de códons, contendo os códons CHEV, BJOR e BIT. Chamamos essa nova classificação "CHEV+" 53 e, para fins de comparação de poder estatístico dos LRTs, algumas das análises descritas na próxima subseção foram feitas também com códons CHEV+.

\subsection{Alvos de seleção em $H L A$ : alelos individuais ou linhagens alélicas?}

As análises descritas a seguir foram feitas para as bases de dados CR e SR baseadas na classificação CHEV.

Nas bases de dados CHEV (CR), a razão $\omega_{(A R S)}$ estimada foi maior para ramos "E" do que para ramos "I" nos três locos (ver tabela 19 na página seguinte). Na base de dados SR obtivemos resultados qualitativamente semelhantes, embora $\omega_{A R S}$ seja menor do que nas bases de dados CR (ver tabela 20 na próxima página). Isso é esperado, assumindo que as micro-conversões tenham transferido sequências de DNA de alelos de uma linhagem para alelos de outra, aumentando, assim, $d_{N}$. Interessantemente, o único caso em que $\omega_{A R S}<1$ é justamente para os ramos "I" da base de dados SR de $H L A-B$. O que poderia gerar esse resultado? Ele está de acordo com a expectativa que tínhamos de que a seleção que atuou sobre os genes $H L A$ foi direcionada principalmente para as linhagens como alvos de seleção e de que tenha sido menos intensa sobre alelos de uma mesma linhagem.

Buscamos verificar se $\omega_{A R S}>1$ é estatisticamente significativo para ramos "E" através de um LRT que comparou o modelo 2 com $\omega$ estimado para ramos "I" e "E" ao modelo 2 com $\omega=1$ (

\footnotetext{
${ }^{52} \mathrm{Na}$ verdade, um dos 30 códons detectados em "BIT" (códon 305) está fora dos éxons 2 e 3 (onde se situa a ARS), por isso não foi incluído nessa comparação, que visou avaliar se há seleção em códons vizinhos aos ARS. Dos 29 códons BIT analisados aqui, portanto, 23 estão em CHEV e 6 estão em CHEV \pm 1.

${ }^{53}$ Essa nova classificação inclui 71 códons (ver figura 14 na página 61 para fins de comparação).
} 
para ramos "E") e $\omega$ estimado para ramos "I". Nas bases de dados com recombinantes, o LRT foi significativo para os $H L A-A$ e $H L A-C$.

O mesmo teste foi aplicado a fim de verificar ver se $\omega>1$ é estatisticamente significativo para ramos "I". Nesse caso, a hipótese nula ( $\omega=1$ para ramos "I") foi rejeitada apenas nas bases de dados $H L A-A$ CR (as tabelas 19 e 20 destacam os valores de $\omega$ significativamente maiores que 1 nesse teste). Já nas bases de dados em que os recombinantes foram removidos, o modelo nulo $\left(\omega_{E}=1\right)$ foi rejeitado apenas em $H L A-B$, em que $\omega_{I}$ é significativamente $<1$ e $H L A-C$, em que $\omega>1$ é significativo (as tabelas 19 e 20 destacam os valores de $\omega$ significativamente maiores que 1 nesse teste).

Tabela 19. Estimativas filogenéticas de $\omega_{A R S}(\mathrm{E} \times \mathrm{I})(\mathrm{CR}, \mathrm{CHEV})$

\begin{tabular}{lccc}
\hline Loco & $\omega_{(A R S)}{ }^{* *}$ & $\omega_{(A R S)}(\mathrm{E})$ & $\omega_{(A R S)}(\mathrm{I})$ \\
\hline$H L A-A$ & 2.22 & $2.42^{*}$ & $2.08^{*}$ \\
$H L A-B$ & 1.405 & 1.73 & 1.08 \\
$H L A-C$ & 1.95 & $7.53^{*}$ & 1.26 \\
\hline * denota significância de $\omega>1\left(\chi_{5 \%}^{2}=3.84,1 g . l\right) ;$ \\
$C R$, com recombinantes; $E$, ramos entre linhagens; \\
$I$, ramos intra linhagens; $C H E V$, classificação ARS \\
utilizada (ver subseção 7.2$).$ \\
**Esse valor refere-se à estimativa feita sob o modelo 0 \\
(um valor de $\omega$ para todos os ramos).
\end{tabular}

Tabela 20. Estimativas filogenéticas de $\omega_{A R S}(\mathrm{E} \times \mathrm{I})(\mathrm{SR}, \mathrm{CHEV})$

\begin{tabular}{lccc}
\hline Loco & $\omega_{(A R S)}^{* *}$ & $\omega_{(A R S)}(\mathrm{E})$ & $\omega_{(A R S)}(\mathrm{I})$ \\
\hline$H L A-A$ & 1.57 & 1.68 & 1.37 \\
$H L A-B$ & 1.28 & $1.54^{*}$ & $0.76^{*}$ \\
$H L A-C$ & 1.62 & 2.65 & $1.14^{*}$ \\
\hline * denota significância de $\omega>1\left(\chi_{5 \%}^{2}=3.84,1 g . l\right) ;$ \\
CR, com recombinantes; $E$, ramos entre linhagens; \\
$I$, ramos intra linhagens; $C H E V$, classificação ARS \\
utilizada (ver subseção 7.2$).$ \\
**Esse valor refere-se à estimativa feita sob o modelo 0 \\
(um valor de $\omega$ para todos os ramos).
\end{tabular}

Testamos a hipótese de que um modelo que permite duas ou mais categorias de ramos com diferentes valores de $\omega($ model $=2)$ se ajusta melhor aos dados do que um modelo com um valor de $\omega$ para todos os ramos (model $=0)$. No modelo alternativo, foram permitidos dois valores de $\omega$, sendo um para ramos "E" (entre linhagens) e o outro para os ramos "I" (intra linhagens), conforme descrito na subseção 5.4 na página 39. Os modelos foram comparados através de um LRT.

Nossa base de dados CR, apenas em $H L A-C$ verificamos ser possível rejeitar o modelo nulo em 
que uma razão $\omega_{A R S}$ é estimada para todas as linhagens (tabela 21). Acreditamos que o resultado desse teste é indicativo de que existem pressões seletivas diferenciadas sobre ramos "I" e "E", sendo mais forte sobre "E", pois no loco em questão, $\omega_{A R S}$ é maior para ramos "E" do que para ramos "I", assim como nos outros dois, em que o LRT não foi significativo. Contrastantemente, o modelo nulo não é rejeitado em nenhum dois locos na base de dados SR (tabela 22).

No caso de $H L A-A$ CR e $H L A-B$ SR, $2 \Delta l<0^{54}$. Na base de dados $H L A-A$ SR esse valor é levemente positivo, porém não significativo.

Tabela 21. Estimativas de parâmetros para ramos E e I (CR, CHEV)

\begin{tabular}{cccccc}
\hline Loco & $l_{0}$ & $l_{1}$ & $n p_{0}$ & $n p_{1}$ & $2 \Delta l$ \\
\hline$H L A-A$ & -1555.76 & -1555.79 & 276 & 277 & -0.06 \\
$H L A-B$ & -2813.29 & -2819.388 & 346 & 347 & -12.2 \\
$H L A-C$ & -1116.24 & -1110.56 & 250 & 251 & $11.36^{*}$ \\
\hline
\end{tabular}

${ }^{*}$ denota significância $\left(\chi_{5 \%}^{2}=3.84,1 g . l\right) ; C R$, com recombinantes. $2 \Delta l=2\left(l_{1}-l_{0}\right)$, onde $l_{1}$ e $l_{0}$ são os valores de verossimilhança do modelo 2 e modelo 0 , respectivamente.

$l_{0}, \log$ da verossimilhança do modelo $0 ; n p_{2}$, número de parâmetros do modelo $2 ; l_{2}, \log$ da verossimilhança do modelo 2; $n p_{2}$, número de parâmetros do modelo 2; CHEV, classificação ARS utilizada (ver subseção 7.2).

Tabela 22. Estimativas de parâmetros para ramos E e I (SR, CHEV)

\begin{tabular}{cccccc}
\hline Loco & $l_{0}$ & $l_{1}$ & $n p_{0}$ & $n p_{1}$ & $2 \Delta l$ \\
\hline$H L A-A$ & -1178.36 & -1178.30 & 208 & 209 & 0.12 \\
$H L A-B$ & -1337.305 & -1339.407 & 142 & 143 & -4.2 \\
$H L A-C$ & -984.25 & -983.48 & 220 & 221 & 1.54 \\
\hline
\end{tabular}

* denota significância $\left(\chi_{5 \%}^{2}=3.84,1 g . l\right) ; S R$, sem recombinantes. $2 \Delta l=2\left(l_{1}-l_{0}\right)$, onde $l_{1}$ e $l_{0}$ são os valores de verossimilhança dos modelos 2 e modelo 0 , respectivamente. $l_{0}, \log$ da verossimilhança do modelo $0 ; n p_{2}$,número de parâmetros do modelo $2 ; l_{2}, \log$ da verossimilhança do modelo 2; $n p_{2}$, número de parâmetros do modelo 2; CHEV, classificação ARS utilizada (ver subseção 7.2).

Para os locos $H L A-A$ e $H L A-B$, o modelo de $\omega$ estimado para ramos "I" e "E" não foi favorecido nem na base de dados CR nem da SR. Por outro lado, rejeitou-se o modelo nulo de que $\omega=1$ para ramos "I" na base de dados CR (tabela 19 na página precedente). Na base de dados SR, o modelo nulo não foi rejeitado em nenhum dos dois testes.

Em resumo, nossos testes mostram que, para os três locos, $\omega>1$ para ramos "E" ao passo que

${ }^{54} 2 \Delta l=2\left(l_{1}-l_{0}\right)$, onde $l_{1}$ e $l_{0}$ são os valores de verossimilhança do modelo 2 e modelo 0 , respectivamente. O fato de, além de não ter sido significativa, a estatística do LRT ter sido negativa, é devido a restrições aos possíveis valores dos parâmetros no programa. Na prática, $2\left(l_{1}-l_{0}\right)<0$ tem o mesmo significado que $2\left(l_{1}-l_{0}\right)=0$. 
apenas em $H L A$ - $A$ CR verificou-se $\omega>1$ significativo para os ramos "E" e "I". Possivelmente essa não significância nos outros locos reflete que a estimativa única fornecida pelo modelo 0 explica os dados tão bem quanto as estimativas do modelo 2. Na tabela 19 percebe-se que as estimativas de $\omega_{E}$ e $\omega_{I}$ para o loco $H L A-A$ (2.42 e 2.08 , respectivamente) têm valores bastante próximos entre si e do valor único fornecido pelo modelo 0 (2.22), o que não é verificado nos outros locos.

A remoção dos recombinantes em nossas análises aumentou o valor de $2 \Delta l$ em $H L A$ - $C$, mas nos outros locos não alterou a significância do teste algo compatível com a teoria (Anisimova et al., 2003).

Por fim, a tabela 23 mostra o resultado da comparacão do modelo 0 ao modelo 2 com $\omega$ estimado para ramos "I" e "E", usando nossa classificação expandida CHEV+. As análises com os códons CHEV + foram feitas apenas para $H L A-A$ CR, uma vez que o efeito de remoção de recombinantes já foi demonstrado nesta subseção e na subseção 7.1 na página 50.

Esperávamos que o aumento de poder estatístico proporcionado pela nova base de dados talvez refletisse em significância do LRT para $H L A$-A. Entretanto, o LRT não foi significativo para $H L A$ $A$ (tabela 23), embora o valor de $2 \Delta l$ tenha aumentado em relação ao obtido com a classificação CHEV.

Tabela 23. Estimativas de parâmetros para ramos E e I (CR, CHEV+)

\begin{tabular}{lccccc}
\hline Loco & $l_{0}$ & $l_{1}$ & $n p_{0}$ & $n p_{1}$ & $2 \Delta l$ \\
\hline$H L A-A$ & -1961.53 & -1961.199 & 272 & 273 & 0.66 \\
\hline * denota significância $\left(\chi_{5 \%}^{2}=3.84,1 g . l\right) ; C R$, com recombinantes. \\
$2 \Delta l=2\left(l_{1}-l_{0}\right)$, onde $l_{1}$ e $l_{0}$ são os valores de verossimilhança \\
dos modelos 2 e modelo 0 , respectivamente. \\
$l_{0}, \log$ da verossimilhança do modelo $0 ; n p_{2}$, número de \\
parâmetros do modelo $2 ; l_{2}, \log$ da verossimilhança do \\
modelo 2; $n p_{2}$, número de parâmetros do modelo $2 ; C H E V+$, \\
classificação ARS utilizada (ver subseção 7.2$).$
\end{tabular}

\subsection{Escala temporal dos eventos de seleção em $H L A$ : seleção em ramos internos e terminais}

Com relação à nossa hipótese de que a seleção atuou mais intensamente sobre ramos internos ("In") do que sobre ramos terminais ("T") da árvore filogenética dos locos $H L A$, o procedimento foi bastante semelhante ao descrito na subseção anterior.

Em geral, o valor de $\omega$ estimado para os ramos internos foi maior do que o valor para os ramos terminais nas bases de dados CR e SR . A única exceção foi em $H L A-A$ (SR). Outra tendência geral é que $\omega_{A R S}>1$ tanto no modelo nulo (um valor de $\omega$ estimado) quanto no modelo alternativo 
(valores de $\omega$ estimados para ramos terminais e internos). A única exceção foi verificada em $H L A-C$ (SR), em que $\omega_{A R S}$ estimado para ramos terminais é $<1$ (ver tabelas 24 e 25).

Tabela 24. Estimativas filogenéticas de $\omega_{A R S}(\operatorname{In} \mathrm{x} \mathrm{T})(\mathrm{CR}, \mathrm{CHEV})$

\begin{tabular}{lccc}
\hline Loco & $\omega_{A R S}{ }^{* *}$ & $\omega_{A R S}(\mathrm{In})$ & $\omega_{A R S}(\mathrm{~T})$ \\
\hline$H L A-A$ & 2.22 & $2.54^{*}$ & 1.96 \\
$H L A-B$ & 1.40 & 1.4 & $1.42^{*}$ \\
$H L A-C$ & 1.95 & $11.24^{*}$ & 0.81 \\
\hline * denota significância de $\omega>1\left(\chi_{5 \%}^{2}=3.84,1 \mathrm{~g} .1\right) ;$ \\
CR, com recombinantes; $M 0$, modelo $0 ;$ In, ramos \\
internos; $T$, ramos terminais; CHEV, classificação \\
ARS utilizada (ver subseção 7.2). \\
**Esse valor refere-se à estimativa feita sob o modelo 0 \\
(um valor de $\omega$ para todos os ramos).
\end{tabular}

A fim de testar se os ramos "In" têm $\omega$ significativamente $>1$, comparamos o modelo 2 com $\omega=1$ para ramos "In" e $\omega$ estimado para ramos "T" e o modelo 2 (alternativo) com $\omega$ estimado para ambas as categorias. O único caso em que o modelo alternativo não foi favorecido foi em $H L A-B$ SR (as tabelas 24 e 25 destacam os valores de $\omega$ significativamente maiores que 1 nesse teste).

O mesmo teste foi aplicado a fim de verificar ver se $\omega>1$ é estatisticamente significativo para ramos "T". Apenas em $H L A-A$ o modelo nulo $\omega_{T}=1$ foi rejeitado. Nas bases de dados SR ele não foi rejeitado em nenhum dos locos. De fato, não esperávamos significância nesse teste para o loco $H L A-C$ (CR e SR), uma vez que as tabelas 24 e 25 mostram que $\left.\omega_{T}<1\right)$.

Os valores de $\omega$ estimados tendem a ser menores nas bases de dados SR, com exceção do loco $H L A-B$, para o qual esses valores sobem (tabelas 24 e 25 ).

Tabela 25. Estimativas filogenéticas de $\omega_{A R S}(\operatorname{In} \times \mathrm{T})(\mathrm{SR}, \mathrm{CHEV})$

\begin{tabular}{cccc}
\hline Loco & $\omega_{A R S}{ }^{* *}$ & $\omega_{A R S}(\mathrm{In})$ & $\omega_{A R S}(\mathrm{~T})$ \\
\hline$H L A-A$ & 1.57 & $2.58^{*}$ & 1.1 \\
$H L A-B$ & 1.28 & 1.55 & 0.91 \\
$H L A-C$ & 1.62 & $3.26^{*}$ & $0.86^{*}$ \\
\hline * denota significância de $\omega_{T}>1\left(\chi_{5 \%}^{2}=3.84,1 \mathrm{~g} .1\right) ;$ \\
SR, sem recombinantes; $M 0$, modelo 0; In, ramos \\
internos; $T$, ramos terminais; CHE $V$, classificação \\
ARS utilizada (ver subseção 7.2). \\
**Esse valor refere-se à estimativa feita sob o modelo 0 \\
(um valor de $\omega$ para todos os ramos).
\end{tabular}

Testamos a hipótese de que de que um modelo que permite duas ou mais categorias de ramos com diferentes valores de $\omega($ model $=2$ ) se ajusta melhor aos dados do que um modelo com um valor de $\omega$ para todos os ramos (model $=0)$. O modelo nulo foi rejeitado apenas para o loco $H L A-C$, nas 
bases de dados CR e SR (tabelas 26 e 27).

Ao compararmos estimativas de $\omega$, testamos a hipótese de que alelos remotamente divergidos teriam maior evidência de seleção balanceadora do que alelos com menor divergência. Talvez nosso método não tenha sido adequado para detectar essas diferenças, uma vez que, embora muitos ramos terminais sejam curtos e correspondam a alelos de uma mesma linhagem, outros são longos e divergiram das outras linhagens há muito tempo. Para lidar com essa questão, em estudos futuros iremos colocar esses ramos terminais longos em uma outra categoria, e novamente testar a hipótese de que $\omega_{I n}>\omega_{T}$.

Por fim, a tabela 28 na página seguinte mostra o resultado da comparacão do modelo 0 ao modelo 2 com $\omega$ estimado para ramos "In" e "T", usando nossa classificação expandida CHEV+. As análises com os códons $\mathrm{CHEV}+$ foram feitas apenas para $H L A-A \mathrm{CR}$, uma vez que o efeito de remoção de recombinantes já foi demonstrado nesta subseção e na subseção 7.1 na página 50 .

Tabela 26. Estimativas de parâmetros para ramos In e T (CR, CHEV)

\begin{tabular}{cccccc}
\hline Loco & $l_{0}$ & $l_{1}$ & $n p_{0}$ & $n p_{1}$ & $2 \Delta l$ \\
\hline$H L A-A$ & -1555.76 & -1555.87 & 276 & 277 & -0.22 \\
HLA-B & -2813.29 & -2811.81 & 346 & 347 & 2.96 \\
HLA-C & -1116.24 & -1108.29 & 250 & 251 & $15.9^{*}$ \\
\hline
\end{tabular}

* denota significância $\left(\chi_{5 \%}^{2}=3.84,1 g . l\right) ; C R$, com recombinantes. $2 \Delta l=2\left(l_{1}-l_{0}\right)$, onde $l_{1}$ e $l_{0}$ são os valores de verossimilhança dos modelos 2 e modelo 0 , respectivamente.

$l_{0}, \log$ da verossimilhança do modelo $0 ; n p_{2}$, número de parâmetros do modelo $2 ; l_{2}, \log$ da verossimilhança do modelo $2 ; n p_{2}$, número de parâmetros do modelo $2 ; C H E V$, classificação ARS utilizada (ver subseção 7.2).

Tabela 27. Estimativas de parâmetros para ramos In e T (SR, CHEV)

\begin{tabular}{cccccc}
\hline Loco & $l_{0}$ & $l_{1}$ & $n p_{0}$ & $n p_{1}$ & $2 \Delta l$ \\
\hline$H L A-A$ & -1178.36 & -1177.39 & 208 & 209 & 1.94 \\
$H L A-B$ & -1337.30 & -1339.02 & 142 & 143 & -3.44 \\
$H L A-C$ & -984.25 & -981.11 & 220 & 221 & $6.28^{*}$
\end{tabular}

* denota significância $\left(\chi_{5 \%}^{2}=3.84,1 g . l\right) ; S R$, sem recombinantes. $2 \Delta l=2\left(l_{1}-l_{0}\right)$, onde $l_{1}$ e $l_{0}$ são os valores de verossimilhança do modelo 2 e modelo 0 , respectivamente.

$l_{0}, \log$ da verossimilhança do modelo $0 ; n p_{2}$, número de parâmetros do modelo $2 ; l_{2}, \log$ da verossimilhança do modelo $2 ; n p_{2}$, número de parâmetros do modelo $2 ; C H E V$ classificação ARS utilizada (ver subseção 7.2). 
Tabela 28. Estimativas de parâmetros para ramos In e $\mathrm{T}(\mathrm{CR}, \mathrm{CHEV}+)$

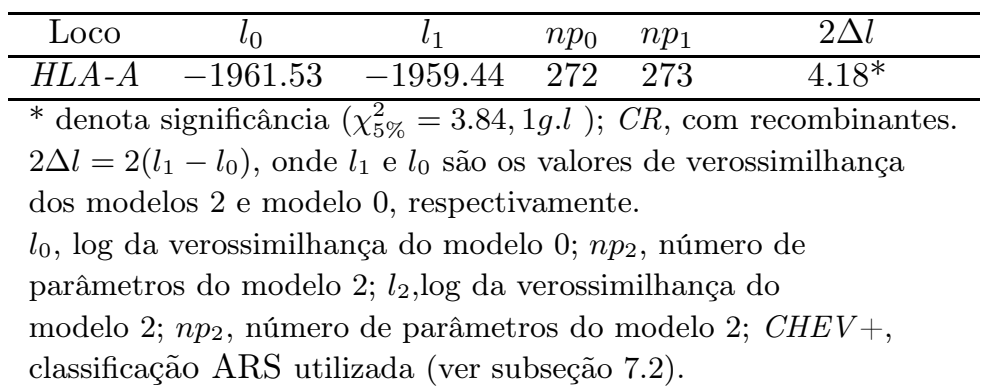




\section{Discussão e Conclusão}

O presente projeto pretendeu examinar os padrões de seleção nos locos clássicos de $H L A$, através do uso de abordagens baseadas em $d_{N} / d_{S}$ como assinatura de seleção natural. Buscamos investigar se a seleção atuou apenas remotamente na diversificação dos alelos de $H L A$ (ou seja, se ela atuou sobre linhagens alélicas como alvos de seleção) ou também recentemente, dentro das linhagens (alelos como alvos de seleção). Podemos resumir nossas conclusões em três tópicos: (a) validação das classificações ARS disponíveis; (2) efeito de alelos recombinantes sobre estimativas de parâmetros e testes de seleção de modelos em escala filogenética e; (3) evidências de seleção intra e entre-linhagens e em diferentes níveis de divergência alélica em $H L A$.

Utilizamos os modelos de seleção sobre códons para obter uma lista de códons selecionados em $H L A-A, H L A-B$ e $H L A-C$. Essas análises nos mostraram que todos os códons selecionados que descrevemos são ARS ou estão situados na "vizinhança" dos códons ARS (até \pm 1 códon de distância). Concluímos, portanto, que poderíamos aumentar nosso poder estatístico se criássemos uma lista mista de códons, sobrepondo duas classificações de códons ARS e incluindo, ainda, os códons com evidência de seleção que encontramos em nossas análises. Chamamos essa nova classificação de "CHEV+". Com isso, aumentamos a nossa base de dados de códons-alvo de seleção de 48 para 71, a fim de aumentar nosso poder estatístico em análises do tipo que empreendemos. Futuramente, pretendemos investigar se a concentração desses códons selecionados perto dos códons ARS sugere que classificações anteriores estão "deixando escapar" alguns casos reais de seleção, ou se alguma outra propridade da evolução molecular dos genes $H L A$ poderia explicar tais resultados.

Nossas análises com e sem recombinantes na abordagem filogenética de site models e branch models permitiram avaliar a importância da existência de recombinação em genes $H L A$ para as inferências feitas a partir de modelos que assumem uma única topologia filogenética e ausência de recombinação. A recombinação afeta a topologia de árvores filogenéticas em, pelo menos, três formas: (1) tornando os ramos terminais mais longos; (2) fazendo com que a árvore difira mais da topologia esperada caso as sequências estivessem evoluindo através de um relógio molecular e; (3) acentuando evidências de polimorfismos antigos (evolução trans-específica) ${ }^{55}$ (Schierup e Hein, 2000, 2000a).

Análises empíricas sugerem que a topologia não tem muito impacto sobre os testes de seleção positiva voltados para a identificação de sítios - e, consequentemente, que a recombinação não gera muitos falsos positivos no LRT (Yang e Bielawski, 2000). Já em estudos feitos com simulações, mostrou-se que a detecção de seleção positiva usando site models pode ser afetada se as sequências

\footnotetext{
${ }^{55}$ A definição de polimorfismo trans-específico foi dada na subseção 2.2 na página 17.
} 
tiverem sofrido substancial recombinação. Em um estudo sobre pressões seletivas sobre diferentes códons de genes de classe I, que será discutido a seguir, Yang e Swanson (2002) não discutem a possível interferência da recombinação em $H L A$ sobre as inferências baseadas nos site models. Já Furlong e Yang (2008), em uma análise semelhante para DRB de mamíferos, não encontraram sinais de recombinação no gene.

Acreditamos ter contribuído para a questão do efeito de sequências recombinantes sobre testes de modelos e estimativas de parâmetros em escala filogenética. Em nossas análises com os site models, percebemos que, embora não tenham havido diferenças na significância dos LRTs entre as bases de dados CR e SR, houve alguma diferença entre as bases de dados CR e SR em termos de quais códons apresentam evidências de seleção positiva.

Nos testes de hipóteses de seleção sobre ramos específicos da árvore filogenética, a influência dos recombinantes sobre os LRTs foi bastante expressiva, em geral tornando o teste não significativo ou reduzindo o valor de sua estatística. Destacamos, com base nessas observações, que alelos recombinantes afetam significativamente inferências de seleção e que as interpretações de testes de seleção devem sempre levar em conta essa influência.

Nas análises par-a-par, observamos que $\omega_{A R S}$ para o último quartil de divergência é sempre maior do que para o primeiro. Esses resultados apontaram para uma possível correlação positiva entre $\omega_{A R S}$ e tempo de divergência dos alelos. A significância dessa correlação foi confirmada através dos testes de Mantel (as correlações estão fora da distribuição de valores que ocorreria ao acaso) e, em $H L A$ - $A$, através de uma simulação.

Também através das análises par-a-par, observamos, para os três locos, um $d_{N} / d_{S}$ maior entre alelos de linhagens distintas $\left(\omega_{A R S}(E)>\omega_{A R S}(I)\right)$. A significância deste resultado foi demonstrada através da comparação não-paramétrica de médias entre essas duas categorias.

$\mathrm{Na}$ abordagem filogenética, ao estimar $\omega_{A R S}$ para as categorias entre e intra-linhagens ("E" e "I"), a tendência geral que observamos foi de que esse valor é maior para a categoria "E". O teste formal de hipóteses favoreceu o modelo em que $\omega$ foi estimado para ambas as categorias apenas em $H L A-C$. Em $H L A-A$ e $H L A-B$ a hipótese nula de um valor de $\omega$ para todas as linhagens não pode ser descartada. Todavia, $\omega_{A R S}(E)>\omega_{A R S}(I)$ é um resultado com significância estatística nos três locos, com base nas análises par-a-par. Essas observações apoiam nossa hipótese de que o principal alvo da seleção sobre genes $H L A$ foram as linhagens.

Testamos novamente a hipótese de que $\omega_{A R S}$ é diferente entre "I" e "E" no loco $H L A-A$ usando nossa classificação expandida de códons $\mathrm{CHEV}+$. O LRT permaneceu não significativo, embora o valor da estatística tenha aumentado. 
Nas comparações entre ramos terminais e internos, a hipótese nula de que as pressões seletivas são iguais em todos os ramos foi rejeitada apenas em $H L A$-C. Por outro lado, constatamos que $\omega_{A R S}(\operatorname{In})>\omega_{A R S}(T)$ nos três locos. Essas observações indicam haver diferenças nas intensidades de seleção em ramos terminais e internos. Uma observação interessante é que em $H L A$-A e $H L A$-B, tanto $\omega_{I}$ quanto $\omega_{T}>1$, ao passo que, em $H L A-C$, apenas $\omega_{I n}>1$. Esse resultado pode ser um indício de que, em $H L A-A$ e $H L A-B$, a seleção possa ter sido semelhante para os alelos e as linhagens, e que ela tenha atuado entre alelos remota e recentemente divergidos. Essa hipótese, se comprovada, poderia explicar porque não conseguimos descartar o modelo nulo para o loco $H L A-A$ (um valor de $\omega$ para todos os ramos da árvore) mesmo quando usamos nossa classificação expandida de códons ARS, a fim de aumentar o poder estatístico.

Embora as estimativas de $\omega$ tenham sido maiores para ramos internos do que para ramos terminais, o modelo nulo que estimou um valor de $\omega$ para todos os ramos só foi rejeitado em $H L A$-C. Com base nessas análises concluímos, portanto, que as diferenças entre alelos filogeneticamente mais próximos devam ter consequências seletivas tão importantes quanto as diferenças entre alelos mais divergentes. Meyer (2004) havia mostrado resultados semelhantes, usando métodos também semelhantes. Entretanto, conforme destacamos na discussão, os ramos terminais longos podem ter influenciado nossos resultados. Futuramente, pretendemos excluir o efeito dos ramos terminais longos, colocando-os em uma categoria à parte.

Nossas conclusões finais são: (a) modelos que assumem que a variação dentro de linhagens é neutra foram rejeitados; (b) a hipótese de homogeneidade no regime de seleção ao longo de toda a filogenia também foi rejeitada.

Nossos resultados mostram que nossos sistema de estudo (genes $H L A$ ) tem diferenças na intensidade de seleção dentro e entre linhagens, sugerindo que linhagens de fato constituem níveis de organização biológica com propriedades que a seleção natural "enxerga". Entretanto, a variação alélica dentro de linhagens também apresenta padrões de variação incompatíveis com neutralidade, e nossos resultados mostram que há substancial evidência de seleção nesse nível, sugerindo que as diferenças entre alelos também são enxergadas pela seleção natural. 


\section{Referências}

Abbas A, Lichtman A, Pober J (2000) Cellular and Molecular Immunology. Library of Congress Cataloging in Publication, Philadelphia, 4th edition.

Allison AC (1954) Protection Afforded by Sickle-cell Trait Against Subtertian Malarial Infection. British Medical Journal 1:290-294.

Andrés AM, Hubisz MJ, Indap A, Torgerson DG, Degenhardt JD, Boyko AR, Gutenkunst RN, White TJ, Green ED, Bustamante CD, Clark AG, Nielsen R (2009) Targets of balancing selection in the human genome. Molecular Biology and Evolution 26:2755-64.

Anisimova M, Nielsen R, Yang Z (2003) Effect of recombination on the accuracy of the likelihood method for detecting positive selection at amino acid sites. Genetics 164:1229-36.

Asthana S, Schmidt S, Sunyaev SR (2005) A limited role for balancing selection. Trends in Genetics 21:30-32.

Bamshad M, Wooding SP (2003) Signatures of natural selection in the human genome. Genetics 4:99-111.

Barouch D, Friede T, Stevanovic S, Ruff LR, Potts WK (1995) HLA-A2 subtypes are functionally distinct in peptide binding and presentation. Journal of Experimental Medicine 182:1847-1856.

Becker KG, Simon RM, Bailey-Wilson JE, Freidlin B, Biddison WE, McFarland HF, Trent JM (1998) Clustering of non-major histocompatibility complex susceptibility candidate loci in human autoimmune diseases. Proceedings of the National Academy of Sciences of the United States of America 95:9979-9984.

Bernatchez L, Landry C (2003) MHC studies in nonmodel vertebrates: what have we learned about natural selection in 15 years? Journal of Evolutionary Biology 16:363-377.

Bersaglieri T, Sabeti PC, Patterson N, Vanderploeg T, Schaffner SF, Drake JA, Rhodes M, Reich DE, Hirschhorn JN (2004) Genetic signatures of strong recent positive selection at the lactase gene. American Journal of Human Genetics 74:1111-20.

Bjorkman PJ, Saper MA, Samraoui B, Bennett WS, Strominger JL, Wiley DC (1987) Structure of the human class I histocompatibility antigen, HLA-A2. Nature 329:506-12.

Borghans J, Beltman J, Boer R (2004) MHC polymorphism under host-pathogen coevolution. Immunogenetics 55:732-739. 
Bubb KL, Bovee D, Buckley D, Haugen E, Kibukawa M, Paddock M, Palmieri A, Subramanian S, Zhou Y, Kaul R, Green P, Olson MV (2006) Scan of human genome reveals no new Loci under ancient balancing selection. Genetics 173:2165-77.

Bustamante CD, Fledel-Alon A, Williamson S, Nielsen R, Hubisz MJ, Glanowski S, Tanenbaum DM, White TJ, Sninsky JJ, Hernandez RD, Civello D, Adams MD, Cargill M, Clark AG (2005) Natural selection on protein-coding genes in the human genome. Nature 437:1153-1157.

Cai JJ, Macpherson JM, Sella G, Petrov DA (2009) Pervasive Hitchhiking at Coding and Regulatory Sites in Humans. PLoS Genetics 5:1-13.

Campbell N (1996) Biology The Benjamin/Cummings Publishing Company, 4 edition.

Carrington M, Nelson G, Martin MP, Kissner T, Vlahov D, Goedert J, Kaslow R, Buchbinder S, Hoots K, O'Brien S (1999) HLA and HIV-1: heterozygote advantage and B*35-Cw*04 disadvantage. Science 283:1748-1752.

Charlesworth D (2006) Balancing selection and its effects on sequences in nearby genome regions. PLoS Genetics 2:379-384.

Chelvanayagam G (1996) A roadmap for HLA-A, HLA-B, and HLA-C peptide binding specificities. Immunogenetics 45:15-26.

Chen JM, Cooper DN, Chuzhanova N, Férec C, Patrinos GP (2007) Gene conversion: mechanisms, evolution and human disease. Nature Reviews Genetics 8:762-75.

Choi S, Park C, Sohn Y, Ko S, Oh H, Kim G, Kim H (2011) Artificial neural network weights of residues for the serological specificities of HLA. International Journal of Immunogenetics 00:1-7.

Clarke B, Kirby D (1966) Maintenance of histocompatibility. Nature 211:999-1000.

Crandall KA, Kelsey CR, Imamichi H, Lane HC, Salzman NP (1999) Parallel evolution of drug resistance in HIV: failure of nonsynonymous/synonymous substitution rate ratio to detect selection. Molecular Biology and Evolution 16:372-82.

Currat M, Trabuchet G, Rees D, Perrin P, Harding R, Clegg J, Langaney A, Excoffier L (2002) Molecular Analysis of the $\beta$-Globin Gene Cluster in the Niokholo Mandenka Population Reveals a Recent Origin of the $\beta$ S Senegal Mutation. The American Journal of Human Genetics 70:207-223.

De Boer RJ, Borghans JaM, van Boven M, Kesmir C, Weissing FJ (2004) Heterozygote advantage fails to explain the high degree of polymorphism of the MHC. Immunogenetics 55:725-731. 
Development Core Team R (2009) R: A language and environment for statistical computing. R Foundation for Statistical Computing, Vienna, Austria.

Doherty PC, Zinkernagel RM (1975) Enhanced immunological surveillance in mice heterozygous at the H-2 gene complex. Nature 256:50-52.

Enard D, Depaulis F, Roest Crollius H (2010) Human and Non-Human Primate Genomes Share Hotspots of Positive Selection. PLoS Genetics 6:1-13.

Fay JC, Wyckoff GJ, Wu CI (2001) Positive and negative selection on the human genome. Genetics 158:1227-34.

Felsenstein J (1984) Distance methods for inferring phylogenies: a justification. Evolution 38:16-24.

Felsenstein J (2005) PHYLIP: phylogenetic inference program (v3.69).

Fisher RA (1930) The genetical theory of natural selection., Vol. 154.

Furlong RF, Yang Z (2008) Diversifying and purifying selection in the peptide binding region of DRB in mammals. Journal of Molecular Evolution 66:384-394.

Gao X, Lester S, Boettcher B, McCluskey J (1997) Diversity of HLA genes in populations of Australia and the Pacific In Genetic diversity of HLA: functional and medical implications., pp. 298-306. EDK.

Gillespie JH (1991) The causes of molecular evolution Oxford University Press, Oxford.

Goldman N, Yang Z (1994) A codon-based model of nucleotide substitution for protein-coding DNA sequences. Molecular Biology and Evolution 11:725-736.

Haldane J (1937) The effect of variation of fitness. American Naturalist 71:1153-1168.

Hamblin M, Thompson E, Dirienzo A (2002) Complex Signatures of Natural Selection at the Duffy Blood Group Locus. The American Journal of Human Genetics 70:369-383.

Harris EE, Meyer D, Gene DD (2006) The Molecular Signature of Selection Underlying Human Adaptations. Yearbook of Physical Anthropology 130:89-130.

Hartl D, Clark AG (1997) Principles of Population Genetics. Sinauer Associates, 3rd edition.

Hasselmann M, Beye M (2006) Pronounced differences of recombination activity at the sex determination locus of the honeybee, a locus under strong balancing selection. Genetics 174:1469-80. 
Haygood R, Babbitt CC, Fedrigo O, Wray GA (2010) Contrasts between adaptive coding and noncoding changes during human evolution. Proceedings of the National Academy of Sciences of the United States of America 107:7853-7857.

Hedrick PW (2002) Pathogen resistance and genetic variation at MHC loci. Evolution 56:1902-1908.

Hedrick PW, Thomson G (1983) Evidence for balancing selection at HLA. Genetics 104:449-56.

Hill AVS (1998) The immunogenetics of human infectious diseases. Annual Review of Immunology 16:593-617.

Hill AVS, Allsopp CEM, Kwiatkowski D, Anstey NM, Rowe PA, Bennett S, Brewster D, McMichael AJ, Greenwood BM (1991) Common west African HLA antigens are associated with protection from severe malaria. Nature 352:595-600.

Hill RE, Hastie ND (1987) Accelerated evolution in the reactive centre regions of serine protease inhibitors. Nature 326:96-99.

Hraber P, Kuiken C, Yusim K (2007) Evidence of human leucocyte antigen heterozygote advantage against hepatitis C infection. Hepatology 46:1713-1721.

Hudson RR, Kreitman M, Aguade M (1987) A Test of Neutral Molecular Evolution Based on Nucleotide Data. Genetics 116:153-159.

Hughes AL, Nei M (1989a) Evolution of the major histocompatibility complex: independent origin of nonclassical class I genes in different groups of mammals. Molecular Biology and Evolution 6:559-79.

Hughes AL, Nei M (1989b) Nucleotide substitution at major histocompatibility complex class II loci: evidence for overdominant selection. Proceedings of the National Academy of Sciences of the United States of America 86:958-962.

Hughes AL, Nei M (1988) Pattern of nucleotide substitution at major histocompatibility class I loci reveals overdominant selection. Letters to Nature 335:167-170.

Jakobsen IB, Wilson SR, Easteal S (1998) Patterns of reticulate evolution for the classical class I and II HLA loci. Immunogenetics 48:312-323.

Janeway C, Travers P, Walport M, Shlomchick M (2004) Immunobiology Garlans Science, 6 edition. Kimura M (1968) Evolutionary rate at the molecular level. Nature 217:624-626. 
Kimura M (1980) A simple method for estimating evolutionary rates of base substitutions through comparative studies of nucleotide sequences. Journal of Molecular Evolution 16:111-120.

Kimura M (1983) The neutral theory of molecular evolution Cambridge University Press.

Kimura M, Crow JF (1963) The Measurement of Effective Population Number. Evolution 17:279-288.

King JL, Jukes TH (1969) Non-Darwinian evolution. Science 164:788-798.

Kingman JFC (2000) Origins of the Coalescent: 1974-1982. Genetics 156:1461-1463.

Klein J (1986) Natural History of the Major Histocompatibility Complex. John Wiley \& Sons, Ltd, New York.

Klein J, Figueroa F (1986) Evolution of the major histocompatibility complex. Critical Reviews in Immunology 6:296-386.

Klein J, Sato A (2000) The HLA system. First of two parts. Advances in Immunology 343:702-709.

Klein J, Takahata N, Ayala J (1993) MHC polymorphism and human origins.

Klein J, Sato A, Nagl S, O’hUigin C (1998) Molecular trans-species polymorphism. Annual Review of Ecology and Systematics 29:1-21.

Klein J, Satta Y, Takahata N, O'hUigin C (1993) Trans-species MHC polymorphisms and the origin of species in primates. Journal of Medical Primatology 22:57-64.

Klitz W, Thomson G, Baur MP (1986) Contrasting evolutionary histories among tightly linked HLA loci. American Journal of Human Genetics 39:340-349.

Kryazhimskiy S, Plotkin JB (2008) The population genetics of dN/dS. PLoS Genetics 4:1-10.

Kumar S, Nei M, Dudley J, Tamura K (2008) MEGA: a biologist-centric software for evolutionary analysis of DNA and protein sequences. Briefings in bioinformatics 9:299-306.

Lawlor DA, Zemmour P, Ennis P, Jackson AP, Parham P (1988) HLA-A and B polymorphisms predate the divergence of human and chimpanzee. Nature 335:268-271.

Lewontin R (1974) The Genetic Basis of Evolutionary Change Columbia University Press, New York.

Maddison W, Maddison D (2010) Mesquite: A modular system for evolutionary analysis. 
Mantel N (1967) The detection of disease clustering and a generalized regression approach. Cancer Research 27:209-220.

Marsh SGE, Albert ED, Bodmer WF, Bontrop RE, Dupont B, Erlich HA, Geraghty DE, Hansen JA, Hurley CK, Mach B, Mayr WR, Parham P, Petersdorf EW, Sasazuki T, Schreuder GMT, Strominger JL, Svejgaard A, Terasaki PI, Trowsdale J (2005) Nomenclature for factors of the HLA system, 2004. International journal of immunogenetics 32:107-59.

Martin DP, Lemey P, Lott M, Moulton V, Posada D, Lefeuvre P (2010) RDP3: a flexible and fast computer program for analyzing recombination. Bioinformatics 26:2462-3.

Mayer W, Jonker M, Klein D, Ivanyi P, van Seventer G, Klein J (1988) Nucleotide sequences of chimpanzee MHC class I alleles: evidence for trans-species mode of evolution. EMBO Journal 7:2765-2774.

McConnell T, Talbot WS, McIndoe RA, Wakeland EK (1988) The origin of MHC class II polymorphism within the genus Mus. Nature 332:651-654.

Meyer D (2004) Nonsynonymous and synonymous substitution rates of HLA class I genes revisited. In 13th International Histocompatibility Workshop and Conference, Vol. 2, pp. 1-3.

Meyer D, Single RM, Mack SJ, Erlich Ha, Thomson G (2006) Signatures of demographic history and natural selection in the human major histocompatibility complex Loci. Genetics 173:2121-2142.

Meyer D, Thomson G (2001) How selection shapes variation of the human major histocompatibility complex: a review. Annals of Human Genetics 65:1-26.

Muller HJ (1950) Our Load of Mutations. The American Journal of Human Genetics 2:111-176.

Muse SV, Gaut BS (1994) A likelihood approach for comparing synonymous and nonsynonymous nucleotide substitution rates, with application to the chloroplast genome. Molecular Biology and Evolution 11:715-724.

Nei M, Gojobori T (1986) Simple methods for estimating the numbers of synonymous and nonsynonymous nucleotide substitutions. Molecular Biology and Evolution 3:418-426.

Nielsen R (2005) Molecular Signatures of Natural Selection. Annual Review of Genetics 39:197-218.

Nielsen R, Bustamante C, Clark A, Glanowski S, Sackton T, Hubisz MJ, Fledel-Alon A, Tanenbaum D, Civello D, White T, J. Sninsky J, Adams M, Cargill M (2005) A Scan for Positively Selected Genes in the Genomes of Humans and Chimpanzees. PLoS Biology 3:e170. 
Nielsen R, Hubisz MJ, Hellmann I, Torgerson D, Andrés AM, Albrechtsen A, Gutenkunst R, Adams MD, Cargill M, Boyko A, Indap A, Bustamante CD, Clark AG (2009) Darwinian and demographic forces affecting human protein coding genes. Genome Research 19:838-49.

Nielsen R, Yang Z (2003) Estimating the Distribution of Selection Coefficients from Phylogenetic Data with Applications to Mitochondrial and Viral DNA. Molecular Biology and Evolution 20:1231-1239.

Ohta T (1995) Synonymous and nonsynonymous substitutions in mammalian genes and the nearly neutral theory. Journal of Molecular Evolution 40:56-63.

Orr HA (2005) The genetic theory of adaptation: a brief history. Nature Reviews Genetics 6:119-27.

Partridge L, Sgrò CM (1998) Behavioural genetics: Molecular genetics meets feeding ecology. Current Biology 8:R23-R24.

Pasvol G, Weatherall DJ, Wilson RJM (1978) Cellular mechanism for the protective effect of haemoglobin S against P. falciparum malaria. Nature 274:701-703.

Penn DJ, Ilmonen P (2005) Major Histocompatibility Complex (MHC) John Wiley \& Sons, Ltd, Chichester, UK.

Posada D, Buckley TR (2004) Model selection and model averaging in phylogenetics: advantages of akaike information criterion and bayesian approaches over likelihood ratio tests. Systematic Biology 53:793-808.

Powell JR, Moriyama EN (1997) Evolution of codon usage bias in Drosophila. Proceedings of the National Academy of Sciences of the United States of America 94:7784-90.

Rambaut A (1996) Se-Al: Sequence Alignment Editor (Se-Al v2.0a11).

Resch AM, Carmel L, Marino-Ramirez L, Ogurtsov AY, Shabalina SA, Rogozin IB, Koonin EV (2007) Widespread Positive Selection in Synonymous Sites of Mammalian Genes. Molecular Biology and Evolution 24:1821-1831.

Richman AD, Herrera LG, Nash D (2001) MHC class II beta sequence diversity in the deer mouse (Peromyscus maniculatus): implications for models of balancing selection. Molecular Eco$\log y$ 5:181-186. 
Robinson J, Waller MJ, Parham P, de Groot N, Bontrop R, Kennedy LJ, Stoehr P, Marsh SGE (2003) IMGT/HLA and IMGT/MHC: sequence databases for the study of the major histocompatibility complex. Nucleic Acids Research 31:311 -314.

Rocha EPC, Smith JM, Hurst LD, Holden MTG, Cooper JE, Smith NH, Feil EJ (2006) Comparisons of $\mathrm{dN} / \mathrm{dS}$ are time dependent for closely related bacterial genomes. Journal of Theoretical Biology 239:226-235.

Sabeti PC, Schaffner SF, Fry B, Lohmueller J, Varilly P, Shamovsky O, Palma A, Mikkelsen TS, Altshuler D, Lander ES (2006) Positive Natural Selection in the Human Lineage. Science 312:1614-1620.

Sabeti PC, Varilly P, Fry B, Lohmueller J, Hostetter E, Cotsapas C, Xie X, Byrne EH, McCarroll Sa, Gaudet R, Schaffner SF, Lander ES, Frazer Ka, Ballinger DG, Cox DR et al. (2007) Genome-wide detection and characterization of positive selection in human populations. Nature 449:913-8.

Saitou N, Nei M (1987) The neighbor-joining method: A new method for reconstructing phylogenetic trees. Molecular Biology and Evolution 4:406-425.

Sato K, Nishio T, Kimura R, Kusaba M, Suzuki T, Hatakeyama K, Ockendon DJ, Satta Y (2002) Coevolution of the S-Locus Genes SRK, SLG and SP11/SCR in Brassica oleracea and B. rapa. Genetics 162:931-940.

Satta Y, O'hUigin C, Takahata N, Klein J (1993) The synonymous substitution rate of the major histocompatibility complex loci in primates. Proceedings of the National Academy of Sciences of the United States of America 90:7480-4.

Schierup MH, Hein J (2000a) Consequences of Recombination on Traditional Phylogenetic Analysis. Genetics 156:879-891.

Schierup MH, Hein J (2000b) Recombination and the Molecular Clock. Molecular Biology and Evolution 17:1578-1579.

She JX, Boehme Sa, Wang TW, Bonhomme F, Wakeland EK (1991) Amplification of major histocompatibility complex class II gene diversity by intraexonic recombination. Proceedings of the National Academy of Sciences of the United States of America 88:453-7.

Stahl EA, Dwyer G, Mauricio R, Kreitman M, Bergelson J (1999) Dynamics of disease resistance polymorphism at the Rpm1 locus of Arabidopsis. Nature 400:667-671. 
Stuart A, Ord K, Arnold S (1999) Kendall's advanced theory on statictics Arnold, London, 6th edition.

Takahata N (1990) A simple genealogical structure of strongly balanced allelic lines and trans-species evolution of polymorphism. Proceedings of the National Academy of Sciences of the United States of America 87:2419-2423.

Takahata N, Nei M (1990) Allelic Genealogy Under Overdominant and Frequency-Dependent Selection and Polymorphism of Major Histocompatibility Complex Loci. Genetics 124:967-978.

Takahata N, Satta Y (1998a) Selection, convergence and intragenic recombination in HLA diversity. Genetica Dordrecht 102:157-159.

Takahata N, Satta Y (1998b) Footprints of intragenic recombination at HLA loci. Immunogenetics 47:430-441.

Templeton AR (2006) Units and targets of selection John Wiley \& Sons, Inc., Hoboken, NJ, USA.

Trachtenberg E, Korber BT, Sollars C, Kepler TB, Hraber PT, Hayes E, Funkhouser R, Fugate M, Theiler J, Hsu YS, Kunstman K, Wu S, Phair J, Erlich HA, Wolinski S (2003) Advantage of rare HLA supertype in HIV disease progression. Nature Medicine 9:928-935.

Voight B, Kudaravalli S, Wen X, Pritchard JK (2006) A Map of Recent Positive Selection in the Human Genome. PLoS Biology 4:446-458.

von Salomé J, Gyllensten U, Bergström TF (2007) Full-length sequence analysis of the HLA-DRB1 locus suggests a recent origin of alleles. Immunogenetics 59:261-71.

Watterson GA (1978) The Homozygosity Test of Neutrality. Genetics 88:405-417.

Wolf JBW, Künstner A, Nam K, Jakobsson M, Ellegren H (2009) Nonlinear dynamics of nonsynonymous $(\mathrm{dN})$ and synonymous $(\mathrm{dS})$ substitution rates affects inference of selection. Genome Biology and Evolution 2009:308-319.

Yang Z (2003) Adaptive Molecular Evolution, chapter 12, p. 1308 Wiley, 2nd edition.

Yang Z (2006) Computational molecular evolution Oxford University Press, Oxford.

Yang Z (2007) PAML 4: Phylogenetic Analysis by Maximum Likelihood. Molecular Biology and Evolution 24:1586-1591. 
Yang Z, Bielawski J (2000) Statistical methods for detecting molecular adaptation. Trends in Ecology \& Evolution 15:496-503.

Yang Z, Nielsen R (1998) Synonymous and nonsynonymous rate variation in nuclear genes of mammals. Journal of Molecular Evolution 46:409-418.

Yang Z, Nielsen R (2000) Estimating synonymous and nonsynonymous substitution rates under realistic evolutionary models. Molecular Biology and Evolution 17:32-43.

Yang Z, Swanson WJ, Vacquier VD (2000) Maximum-likelihood analysis of molecular adaptation in abalone sperm lysin reveals variable selective pressures among lineages and sites. Molecular Biology and Evolution 17:1446-55.

Yang Z, Swanson WJ (2002) Codon-substitution models to detect adaptive evolution that account for heterogeneous selective pressures among site classes. Molecular Biology and Evolution 19:49-57. 


\section{Parte IV}

\section{Anexos}
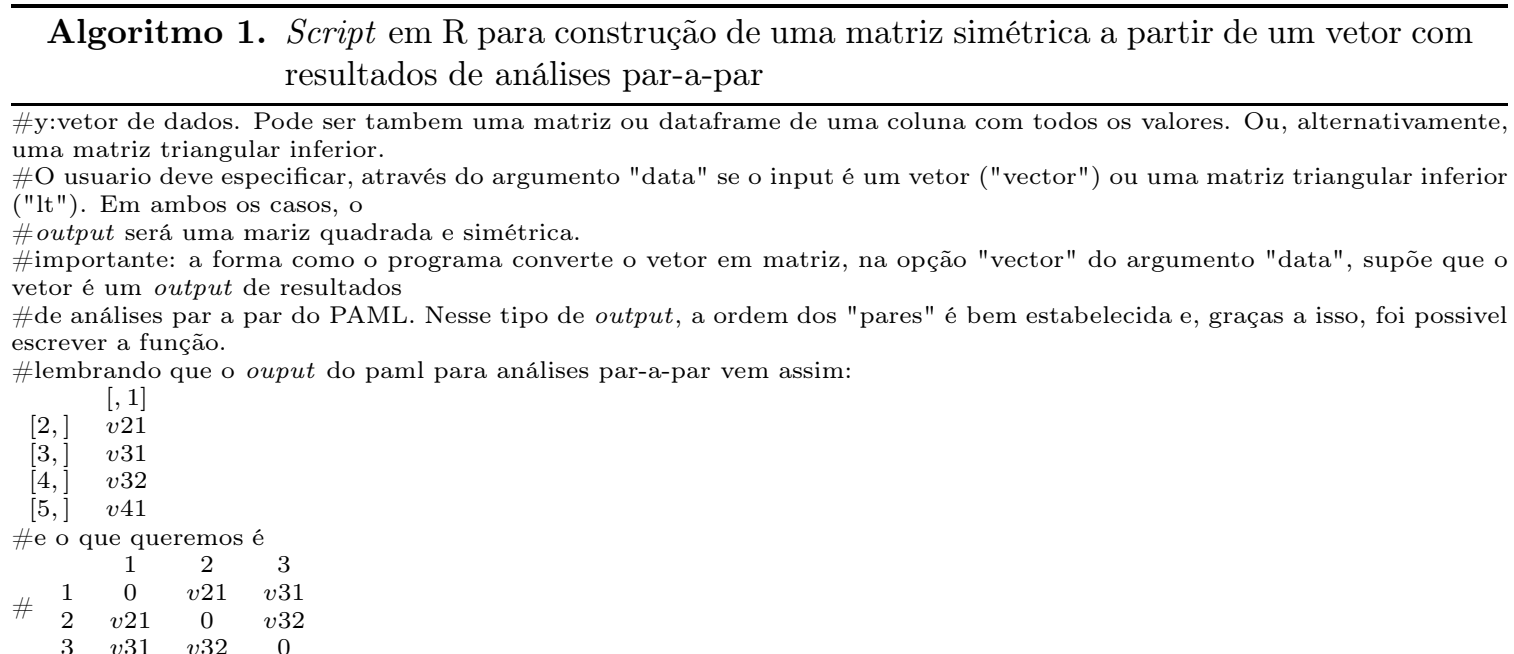

making.matrix $<$-function(y, data $=$ "vector" $)\{$

if $($ data $==$ "vector" $)\{$

length(y)->obs \#logo, pela formula de Bhaskara:

$\# \mathrm{x}=\left(-\mathrm{b}+/-\operatorname{sqrt}\left(\mathrm{b}^{\wedge} 2-4 \mathrm{ac}\right)\right) /(2 \mathrm{a})$

$\# \mathrm{ax}^{\wedge} 2+\mathrm{bx}+\mathrm{c} \# \mathrm{n} *(\mathrm{n}-1) / 2=780$

$\# \mathrm{n}^{\wedge} 2$-n=1560 \#n^2-n-1560

$\#$ delta $=\mathrm{b}^{\wedge} 2-4^{*} \mathrm{a}^{*} \mathrm{c}$ delta $=(-1)^{\wedge} 2-\left(4^{*} 1^{*}\left(-\left(\mathrm{obs}^{*} 2\right)\right)\right)$

$\mathrm{n} 1=-(-1+\operatorname{sqrt}($ delta $)) /\left(2^{*} 1\right)$

$\mathrm{n} 2=-(-1$-sqrt $($ delta $)) /\left(2^{*} 1\right)$

if $(\mathrm{n} 2>\mathrm{n} 1)\{\mathrm{n}<-\mathrm{n} 2\}$

else $\{\mathrm{n}<-\mathrm{n} 1\}$

mat $<$-matrix $($ nrow $=$ n,ncol $=$ n) $\#$ cria matriz vazia pra colocar os valores

for(i in 1:n) $\{$ mat $[\mathrm{i}, \mathrm{i}]<-0\}$ \#agora, colocar primeiro valor da col na segunda linha primeira coluna da matriz

\# um contador tem que conter os elementos "linha" de "mat"

count $<-$ rep $(2: \mathrm{n}, \mathrm{c}(\operatorname{seq}($ from $=1$, to $=\mathrm{n}-1)))$

\#o outro deve conter os elementos "coluna"

count $2<-1$ for(i in $3: n-1)\{$ count $2=c($ count $2, \operatorname{seq}(1: \mathrm{i}))\} \#$ cola os dois

counter $<$-cbind(count, count2) \# comeca o loop.

for $(\mathrm{i}$ in 1:obs) \{ mat [counter[i,1], counter[i,2]] $<-\mathrm{y}[\mathrm{i}]->\operatorname{mat}[\operatorname{counter}[\mathrm{i}, 2]$, counter $[\mathrm{i}, 1]]$ \#numa linha só joga o valor no seu lugar e no lugar simétrico correspondente, pois a matriz é simétrica

\} \}

else $\{$ if $($ data! $=" l t ")\{$

$\operatorname{stop}()\}$

else $\{\mathrm{n}<-\operatorname{dim}(\mathrm{y})[1]$

obs $<-\left(\mathrm{n}^{*}(\mathrm{n}-1)\right) / 2$ for (i in $\left.1: \mathrm{n}\right)\{\mathrm{y}[\mathrm{i}, \mathrm{i}]<-0\}$ \#coloca zeros nas diagonais

count $<-\operatorname{rep}(2: \mathrm{n}, \mathrm{c}(\operatorname{seq}($ from $=1, \mathrm{to}=\mathrm{n}-1))) \#$ o outro deve conter os elementos "coluna"

count $2<-1$ for (i in $3: \mathrm{n}-1)\{$ count $2=\mathrm{c}(\operatorname{count} 2$,seq(1:i)) $\}$ \#cola os dois

counter $<$-cbind(count, count2) \#comeca o loop

$\mathrm{obs}=(\mathrm{n} *(\mathrm{n}-1)) / 2$

for(i in 1:obs) \{

y[counter $[i, 1]$, counter $[i, 2]]->y[\operatorname{counter}[i, 2]$, counter[i,1]] \#numa linha so ja joga o valor no seu lugar e no lugar simétrico correspondente, pois a matriz é simétrica

\} \} \}

if $($ data $==$ "vector" $)\{$ return(mat) $\}$

else $\{\operatorname{return}(\mathrm{y})$

\} \} 


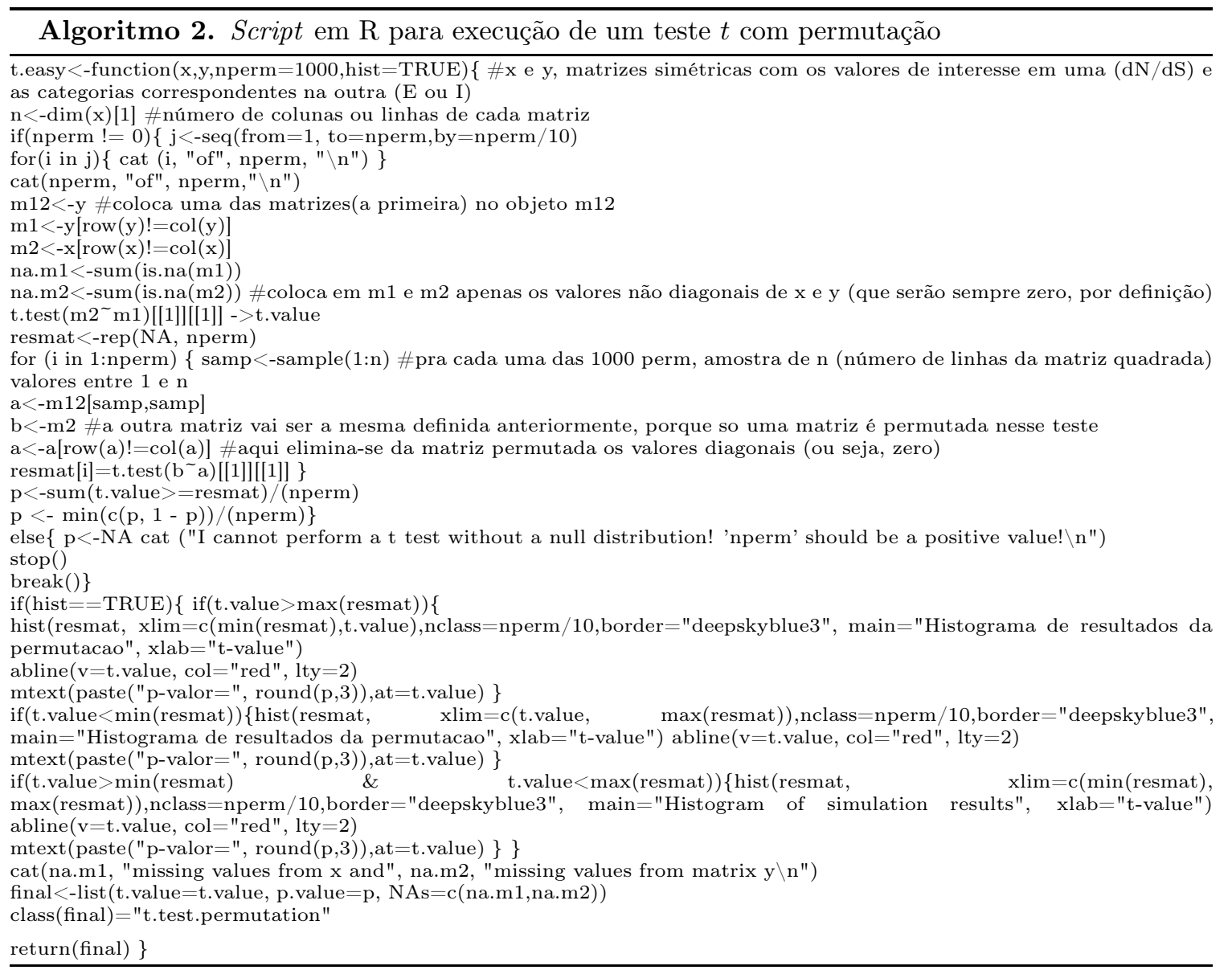




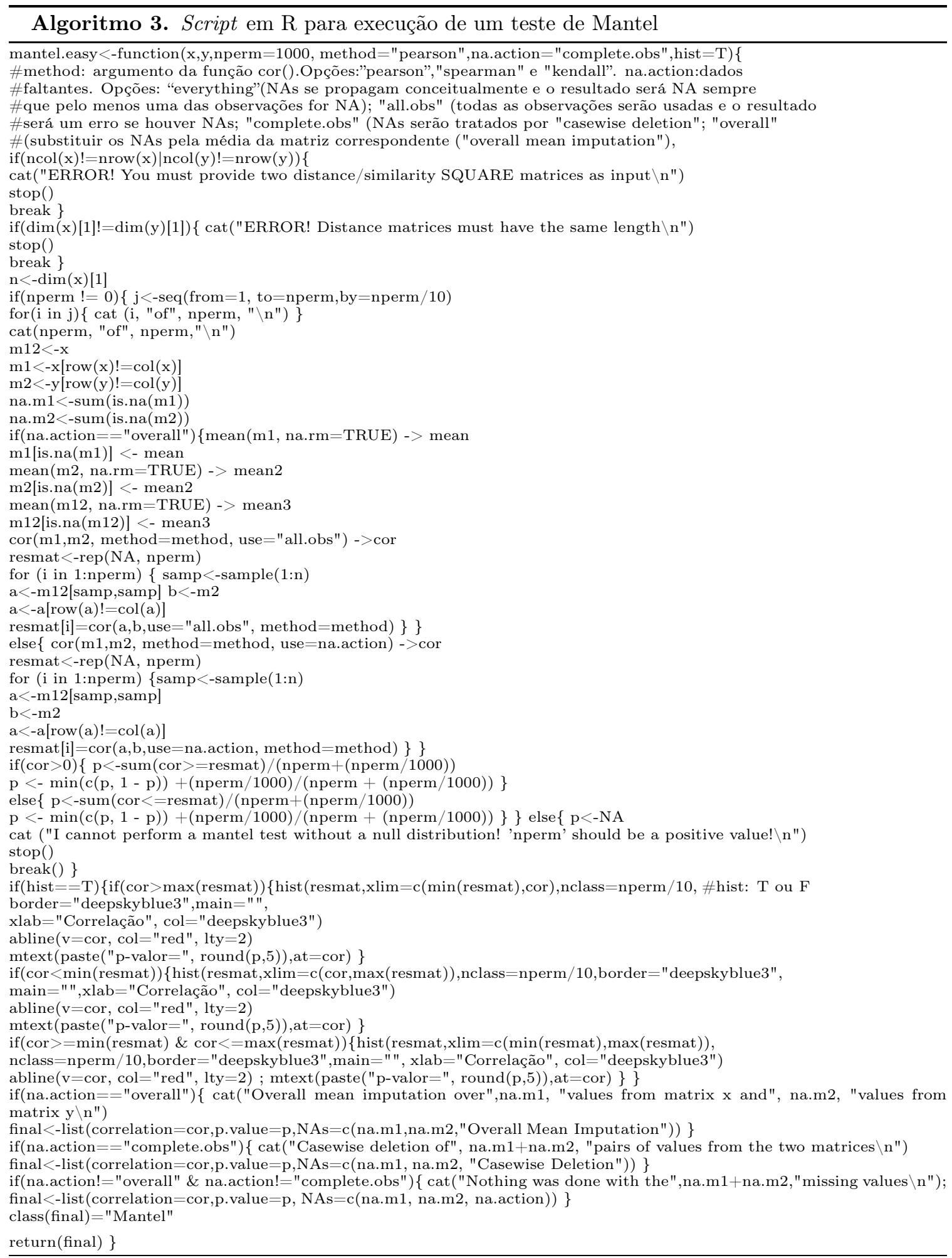




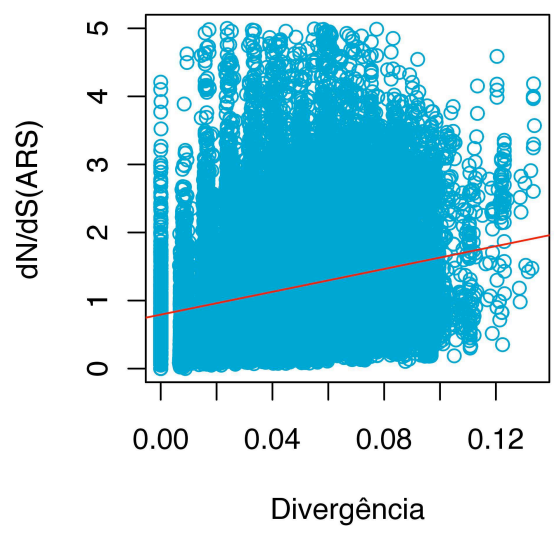

Figura A.1. HLA-B: relação entre $\omega_{A R S}$ e $d_{S(n a \tilde{a} o-A R S)}$. A linha vermelha representa a correlação linear $\left(R^{2}=0.05\right)$ entre as variáveis.

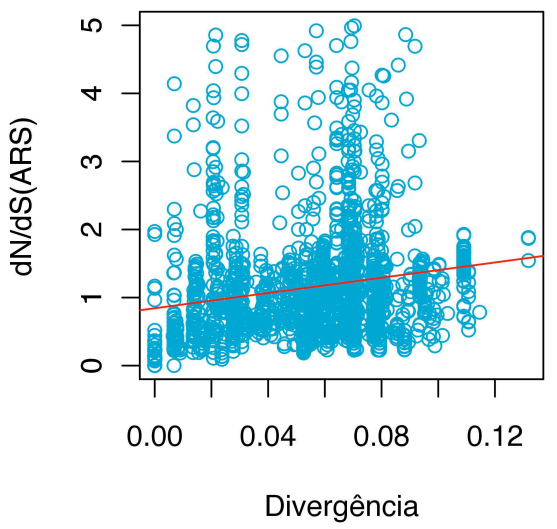

Figura A.2. HLA-C: relação entre $\omega_{A R S}$ e $d_{S(n \tilde{a} o-A R S)}$. A linha vermelha representa a regressão linear $\left(R^{2}=0.03\right)$ entre as variáveis. 

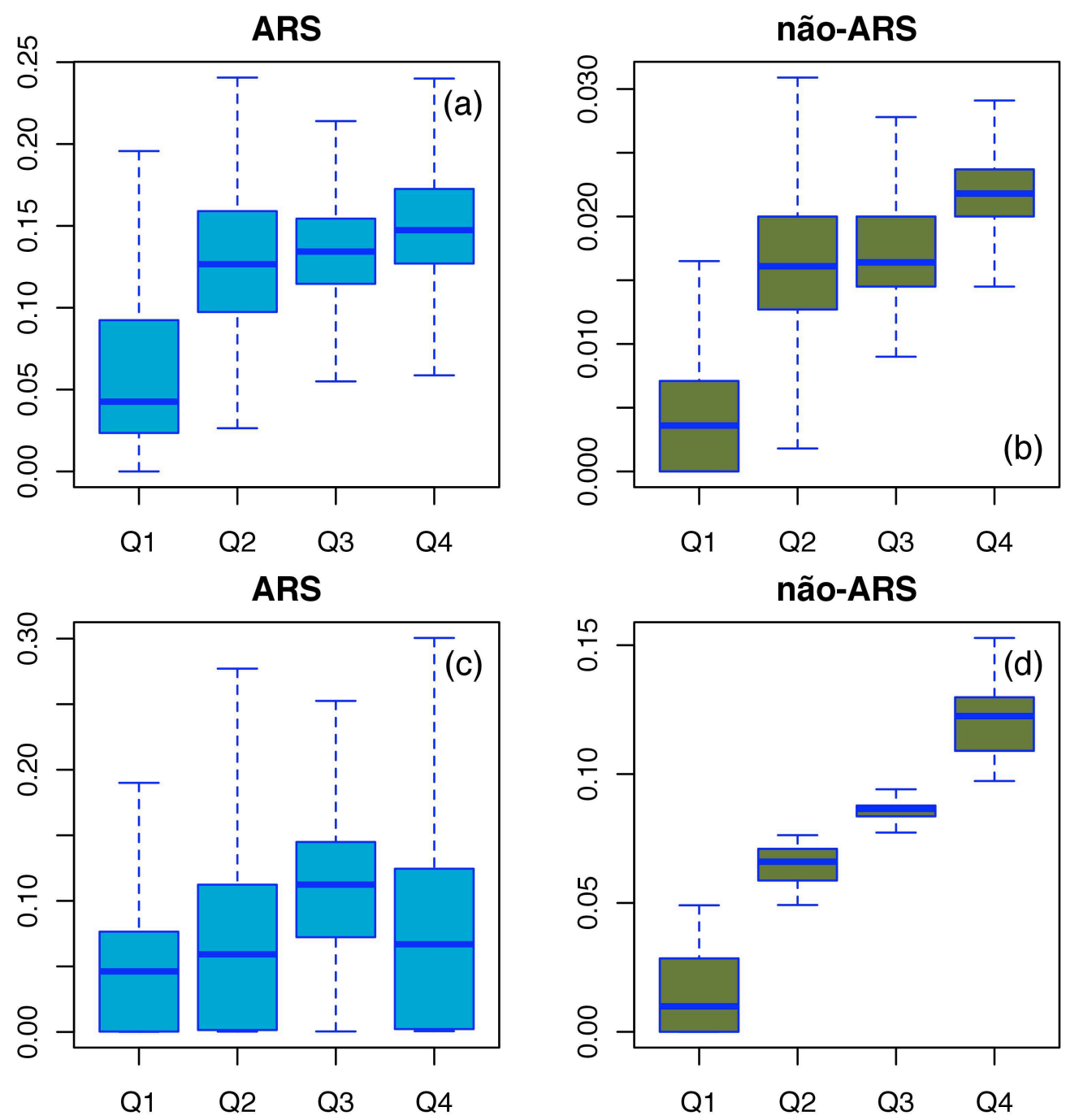

Figura A.3. HLA - A: Comportamento de $d_{N}$ e $d_{S}$ ao longo dos quartis de divergência alélica. Q1-Q4 indicam quartis em ordem crescente de divergência. As figuras (a) e (b) se referem a valores de $d_{N}$; as figuras (c) e (d) referem-se a valores de $d_{S}$. Os valores para as bases de dados não-ARS são mostrados para fins de controle. 


\section{ARS}
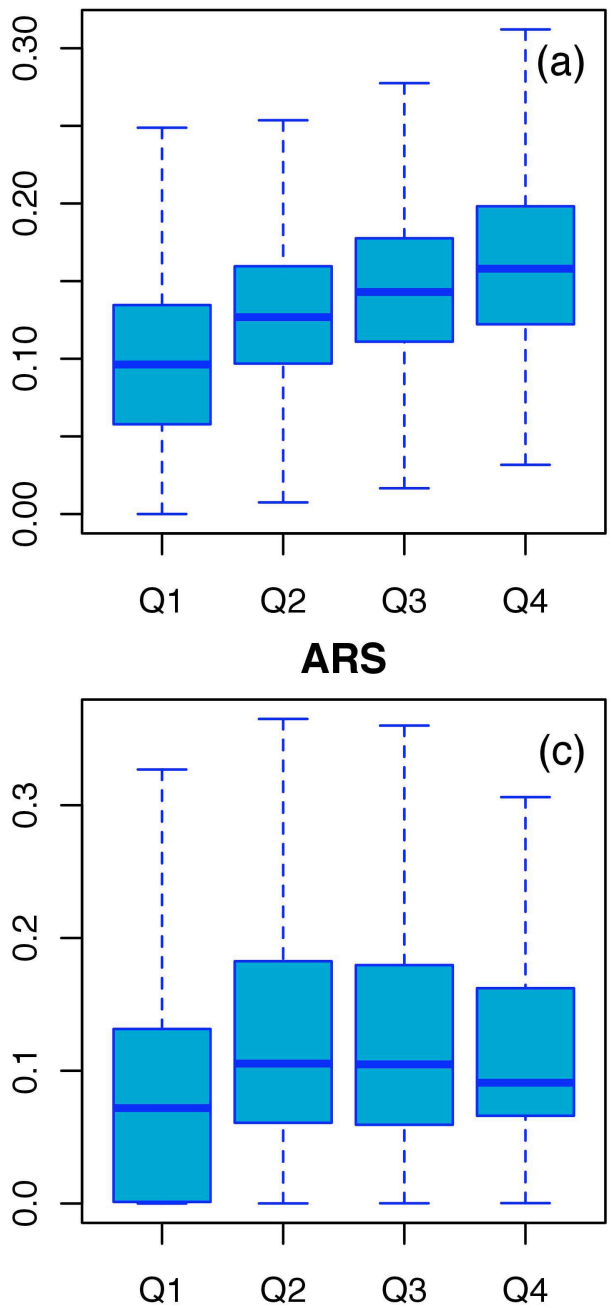

não-ARS
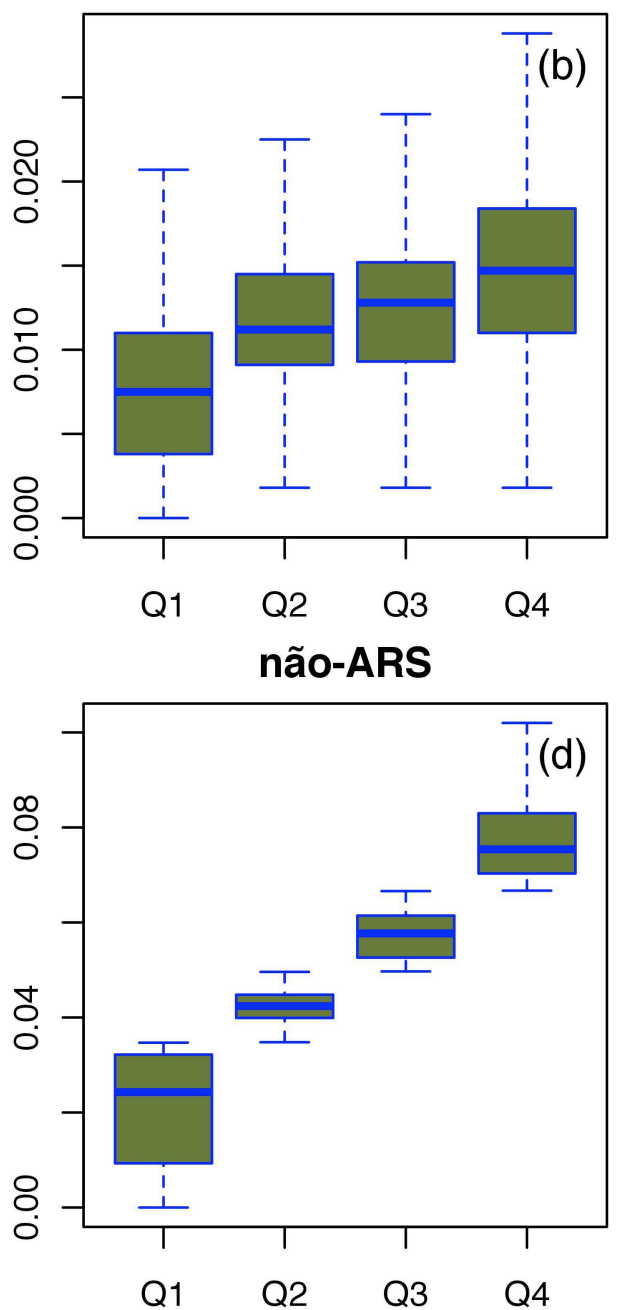

Figura A.4. HLA - B: Comportamento de $d_{N}$ e $d_{S}$ ao longo dos quartis de divergência alélica. Q1-Q4 indicam quartis em ordem crescente de divergência. As figuras (a) e (b) se referem a valores de $d_{N}$; as figuras (c) e (d) referem-se a valores de $d_{S}$. Os valores para as bases de dados não-ARS são mostrados para fins de controle. 


\section{ARS}

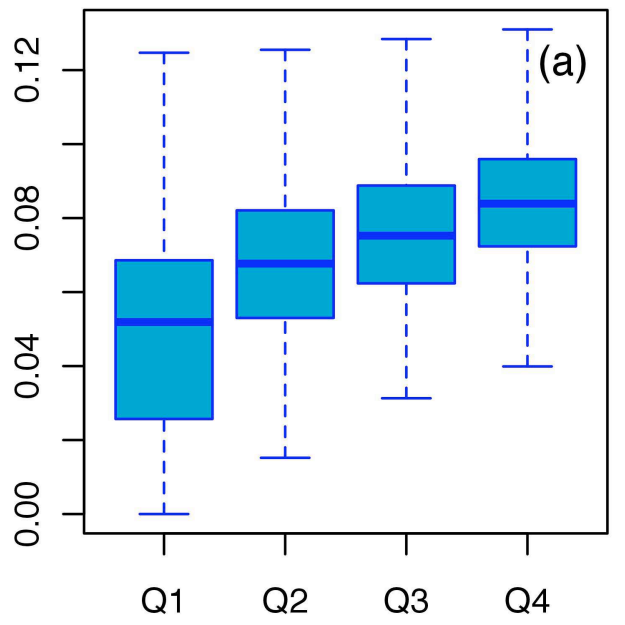

ARS

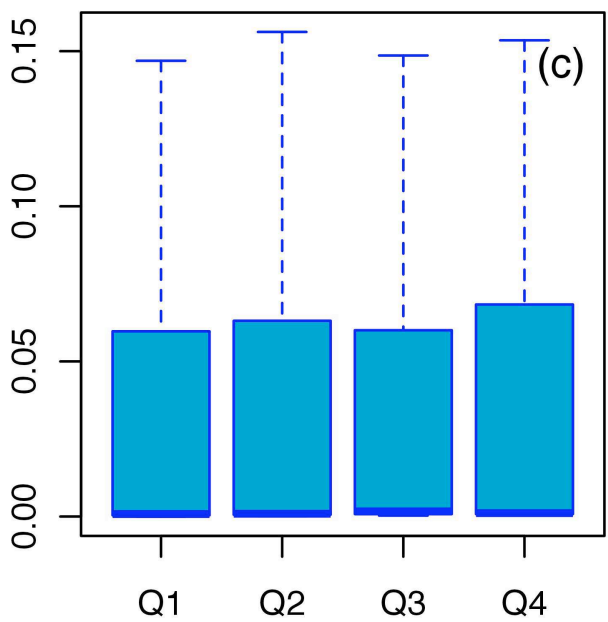

não-ARS
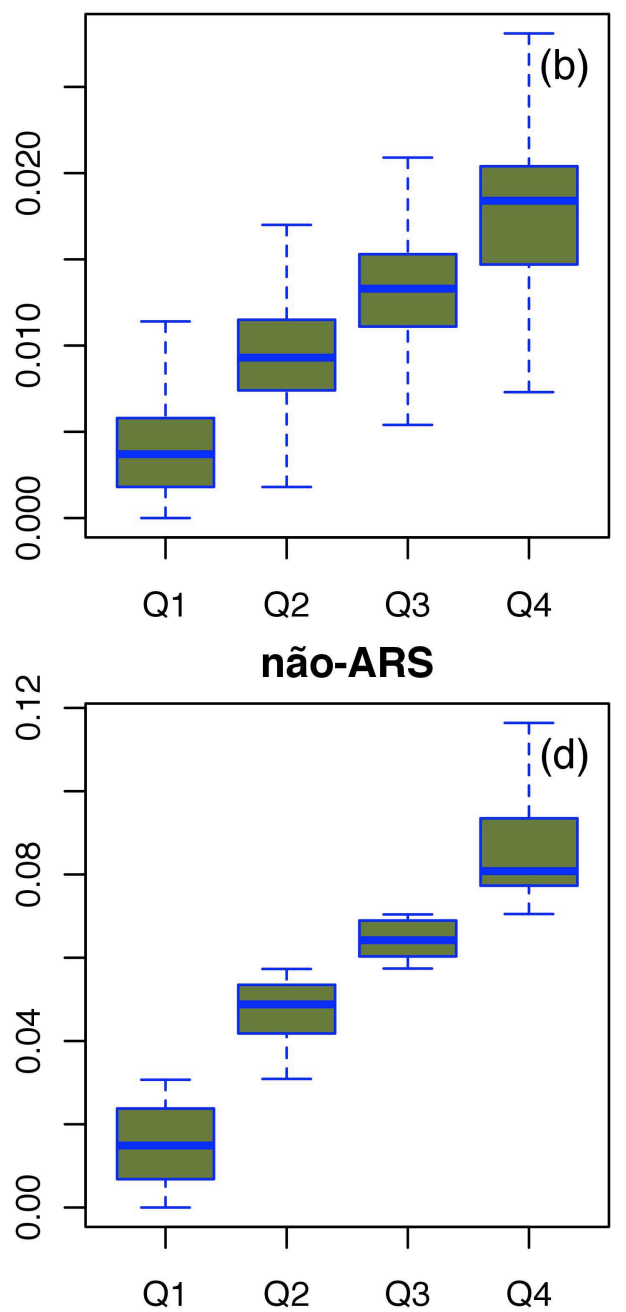

Figura A.5. HLA - C: Comportamento de $d_{N}$ e $d_{S}$ ao longo dos quartis de divergência alélica. Q1-Q4 indicam quartis em ordem crescente de divergência. As figuras (a) e (b) se referem a valores de $d_{N}$; as figuras (c) e (d) referem-se a valores de $d_{S}$. Os valores para as bases de dados não-ARS são mostrados para fins de controle. 


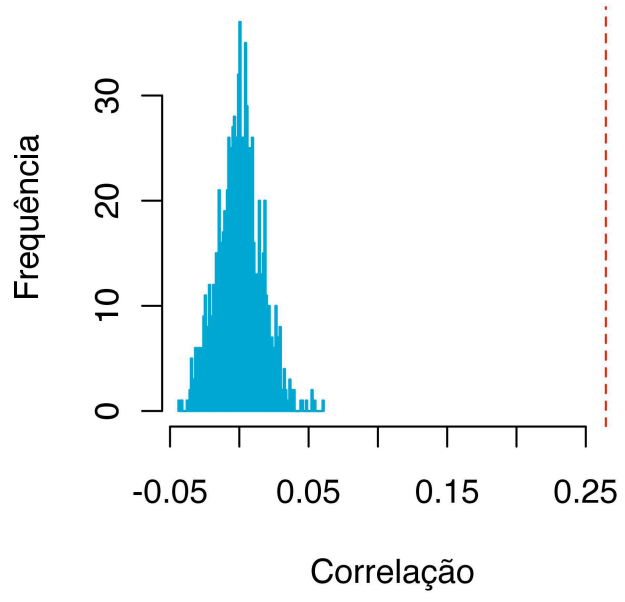

Figura A.6. HLA $\boldsymbol{A}$ : teste de Mantel entre $\omega_{A R S}$ e $d_{S(n \tilde{a} o-A R S)}$. O histograma representa os valores de correlação entre $\omega_{A R S}$ e $d_{S(n \tilde{a} o-A R S)}$ obtidos nas permutações de matrizes do teste de Mantel. A linha vermelha mostra onde se insere o valor empírico de correlação. 